\title{
WestVirginiaUniversity
}

THE RESEARCH REPOSITORY @ WVU

Graduate Theses, Dissertations, and Problem Reports

2009

\section{Examining the role of entrepreneurship in economic development in Appalachia}

Maribel N. Mojica

West Virginia University

Follow this and additional works at: https://researchrepository.wvu.edu/etd

\section{Recommended Citation}

Mojica, Maribel N., "Examining the role of entrepreneurship in economic development in Appalachia" (2009). Graduate Theses, Dissertations, and Problem Reports. 4505.

https://researchrepository.wvu.edu/etd/4505

This Dissertation is protected by copyright and/or related rights. It has been brought to you by the The Research Repository @ WVU with permission from the rights-holder(s). You are free to use this Dissertation in any way that is permitted by the copyright and related rights legislation that applies to your use. For other uses you must obtain permission from the rights-holder(s) directly, unless additional rights are indicated by a Creative Commons license in the record and/ or on the work itself. This Dissertation has been accepted for inclusion in WVU Graduate Theses, Dissertations, and Problem Reports collection by an authorized administrator of The Research Repository @ WVU.

For more information, please contact researchrepository@mail.wvu.edu. 


\title{
EXAMINING THE ROLE OF ENTREPRENEURSHIP IN ECONOMIC DEVELOPMENT IN APPALACHIA
}

\author{
Maribel N. Mojica \\ Dissertation Submitted to the \\ Davis College of Agriculture, Forestry, and Consumer Sciences \\ at West Virginia University \\ in Partial Fulfillment of the Requirements \\ for the Degree of \\ Doctor of Philosophy \\ in \\ Natural Resource Economics \\ Tesfa G. Gebremedhin, Ph.D., Chair \\ Peter V. Schaeffer, Ph.D., Co-Chair \\ Timothy T. Phipps, Ph.D. \\ Dennis K. Smith, Ph.D. \\ Russell S. Sobel, Ph.D.
}

Agricultural and Resource Economics Program

Division of Resource Management

\author{
Morgantown, West Virginia \\ 2009
}

Keywords: Entrepreneurship, Simultaneous Equations, Appalachia, Economic Growth 


\title{
ABSTRACT \\ Examining the Role of Entrepreneurship in Economic Development in Appalachia
}

\author{
Maribel N. Mojica
}

Increasing uncertainty in the world economy has created challenges for regions to pursue development strategies to achieve economic growth. Globalization, increased marketing integration, and the advent of new technologies led to approaches from traditional industrial recruiting to less traditional approaches. Among these latter approaches is the increased importance of entrepreneurship for creating economic growth through establishment of new firms or growth from established firms. An understanding of entrepreneurship becomes important to know how entrepreneurship matters in economic growth and development, and furthermore, how entrepreneurial capacity can be expanded to further the dimensions of economic development. Exploring the characteristics of entrepreneurship and its contributions to the local economy can help develop a map for designing specific development policies for Appalachia.

The main objective of the study is to determine the relationship between regional growth and entrepreneurship. To examine the role of entrepreneurship in economic growth, this study used a regional economic growth model using a system of simultaneous equations. Data on 410 counties of Appalachia is employed where measures of entrepreneurial activity are constructed and regressed against measures of economic growth. The simultaneous equation model is used where the dynamics of population growth, employment growth, and per capita income growth is utilized to determine how regional factors affect patterns of growth. The focus is how entrepreneurial factors influence growth in population, employment, and per capita income. Entrepreneurship variables are constructed from proprietorship and firm births and deaths data. In addition, quality of human capital, agglomeration, poverty, infrastructure, natural amenities, government expenditures, crime, and taxes are used in estimating the models. The growth model is specified as a three- and a four-equation model regressed using ordinary least squares (OLS) and two-stage least squares (2-SLS) regressions. The three-equation growth model is empirically estimated using the methods of two-stage least squares (2-SLS) and ordinary least squares (OLS) regressions. Simultaneous equations are estimated using 2-SLS to account for the endogeneity issue in variables used as both dependent and explanatory variables. These variables include the measures of growth and the constructed entrepreneurship index in the fourequation model.

The results of estimating the change in population equation show that employment growth positively affects population growth. Considering entrepreneurship, firm births and population growth are positively related. In addition, firm death is found to negatively affect change in population. While population density and quality of infrastructure increase county population, percentage of families below poverty level, education, and the initial value of population have negative effects towards population growth. The empirical results in estimating the change in employment equation in both three and four-equation models indicate that growth in population is positively related with employment growth. Therefore, the study further supports the "jobs follow people and people follow jobs" theory. Results also show that employment growth and per capita income growth are positively related. Self-employment and 
firm births are found to have positive effects in determining increases in county employment. Firm death is found to negatively affect employment which further supports the theory on the role of entrepreneurship in increasing job creation. Crime rate is also found to reduce job creation. However, both estimation methods indicate negative relationships between natural amenities ranking and employment growth which is in contrast to the hypothesis. Furthermore, per capita taxes show positive effects in county employment growth. OLS results also show a positive effect of population density and negative effects of property taxes and the share of population 35 to 64 years old towards employment growth.

Empirical results in estimating the per capita income equation show that population growth negatively affects increases in per capita income. The initial value of per capita income is found to be positive in determining per capita income growth in all three estimations. Further, the estimation indicates a negative relationship between growth in firm deaths and per capita income growth. The OLS estimation revealed that increases in the number of self-employed and increases in per capita income are related. The lagged value of per capita income growth is positive in relation to per capita income growth in all three estimations. In addition, the hypothesis on the positive effects of education in increasing income is supported in all three estimations. While the results show positive relationships between the share of population 35 to 64 years old and per capita income growth, negative relationships exist between state road density and change in per capita income. The estimation of the entrepreneurship equation in the four-equation model shows significant relationships with all the other endogenous variables. However, a positive association is observed only between the employment growth and the growth in entrepreneurial activity.

The study recommends supporting the creation of an entrepreneurial environment to encourage entrepreneurial activity as a strategy to increase employment. Furthermore, supporting existing entrepreneurs and avoiding firm deaths may help in achieving economic growth. 


\section{ACKNOWLEDGEMENTS}

I would like to acknowledge and extend my heartfelt gratitude for the support, help, and encouragement of the people who made the undertaking of this dissertation possible and supported me in the course of my study. First, I would like to recognize my advisor, Dr. Tesfa Gebremedhin for his guidance throughout my academic life at West Virginia University, for the constructive comments and corrections, for being available to help at all times, and for all the advice and support. I am very fortunate to have him as my major advisor and it was great pleasure working with him.

I am grateful to Dr. Peter Schaeffer for his constructive criticisms, guidance and help in my research work, and to the rest of my committee members Dr. Tim Phipps, Dr. Dennis Smith, and Dr. Russell Sobel for sharing their insights and for reviewing this manuscript. Special thanks to Dr. Dale Colyer for editing this dissertation and for his comments and suggestions.

I am also thankful to Ms. Lisa Lewis, Ms. Melanie Jimmie, and Ms. Ellen Hartley-Smith for their administrative assistance, for their caring and willingness to help; to Ms. Jacquelyn Strager for sharing GIS data, and to Dr. Alan Collins for a summer funding, for the opportunity to work with him, and for his advice.

My deepest gratitude to the Division of Resource Management, Davis College of Agriculture, Forestry, and Consumer Sciences for the graduate assistantship they provided me.

Special thanks to my family, relatives, colleagues, and friends for all the support, and glory to the Lord Jesus, who made all things possible. 


\section{DEDICATION}

I dedicate this work to my parents Mr. Antonio and Mrs. Angelita Mojica, to my brothers Marlon and Michael, my sisters Melanie and Mabel, to Drs. Kenneth and Rufina Ward for all their love and encouragement, and to Dr. Leonard Howell for his love and inspiration. 


\section{TABLE OF CONTENTS}

Abstract $\quad$ ii

Acknowledgements

Dedication $\quad$ V

List of Tables $\quad$ vi

List of Figures $\quad$ vii

CHAPTER 1: INTRODUCTION

1.1 Introduction and Problem Statement $\quad 1$

1.2 The Study Area $\quad 4$

1.3 Objectives of the Study 16

1.4 Organization of the Study 16

CHAPTER 2: LITERATURE REVIEW 17

2.1 Entrepreneurship and Economic Growth $\quad 17$

2.2 Defining Entrepreneurship 25

$\begin{array}{ll}2.3 \text { Measuring Entrepreneurship } & 29\end{array}$

CHAPTER 3: THEORETICAL FRAMEWORK 35

3.1 The Knowledge Spillover Theory of Entrepreneurship 35

3.2 Stages of Economic Development and Globalization 39

3.3 Entrepreneurship and New Growth Theory 41

3.4 Entrepreneurship as a Filter in Endogenous Growth 44

CHAPTER 4: EMPIRICAL MODEL AND DATA DESCRIPTION 48

4.1 Growth Model $\quad 48$

4.2 Endogeneity Test $\quad 51$

4.3 Specification of Variables $\quad 52$

4.4 Types and Sources of Data $\quad 55$

4.5 Model Estimation Methods 63

CHAPTER 5: EMPIRICAL ANALYSES AND RESULTS 65

5.1 Empirical Estimation $\quad 65$

5.2 Two-Stage Least Squares (2-SLS) Estimation Results: Three-Equation

Growth Model $\quad 69$

5.2.1 Change in Population $\quad 69$

5.2.2 Change in Employment $\quad 71$

5.2.3 Change in Per Capita Income 76

5.3 Ordinary Least Squares (OLS) Estimation Results: Three-Equation 
$\begin{array}{ll}\text { Growth Model } & 77\end{array}$

5.3.1 Change in Population $\quad 78$

5.3.2 Change in Employment $\quad 80$

5.3.3 Change in Per Capita Income $\quad 82$

5.4 Two-Stage Least Squares (2-SLS) Estimation Results: Four-Equation

Growth Model

5.4.1 Change in Population $\quad 85$

5.4.2 Change in Employment 86

5.4.3 Change in Per Capita Income $\quad 87$

5.4.4 Change in Entrepreneurial Activity $\quad 87$

CHAPTER 6: SUMMARY AND CONCLUSIONS 90

$\begin{array}{ll}\text { 6.1 Summary and Conclusions } & 90\end{array}$

6.2 Policy Recommendations $\quad 94$

6.3 Limitations and Future Research 95

6.3.1 Limitations of the Study 95

6.3.2 Recommendations for Future Research 96

$\begin{array}{ll}\text { REFERENCES } & 97\end{array}$

$\begin{array}{ll}\text { APPENDIX } & 103\end{array}$ 


\section{LIST OF TABLES}

Table

\section{Title}

Page

1.1 Top and Bottom 30 Counties: Proprietors per 1000 Labor Force (1995). 9

1.2 Top and Bottom 30 counties: Growth in Proprietors per 1000

Labor Force (1995-2005).

$1.3 \quad$ Top and Bottom 30 Counties: Firm Births per 1000 Labor Force (1998). 11

1.4 Top and Bottom 30 Counties: Growth in Firm Births per 1000

Labor Force (1998-2005).

$1.5 \quad$ Top and Bottom 30 Counties: Firm Deaths per 1000

Labor Force (1998).

4.1 Definition and Sources of Endogenous Variables and Initial Conditions. 56

4.2 Definition and Data Sources of Entrepreneurship Variables. 59

4.3 Definition and Data Sources of Socio-Demographic Variables. 61

4.4 Descriptive Statistics of Endogenous Variables and Initial Conditions. 62

4.5 Descriptive Statistics of Entrepreneurship Variables. $\quad 62$

4.6 Descriptive Statistics of Education, Agglomeration, Infrastructure, Natural amenities, Government Expenditures, Taxes, and Crime Rate. 63

$\begin{array}{lll}\text { 5.1.1 } & \text { Result of Principal Component Analysis. } & 68\end{array}$

5.1.2 Results of Hausman Test for Endogeneity. $\quad 69$

5.2 Two-stage Least Squares (2-SLS) Estimation Results (3-Equation Model). 73

5.3 Ordinary least squares (OLS) estimation results (3-Equation Model). 83

$5.4 \quad$ Two-stage least squares (2-SLS) estimation results (4-Equation Model). 89 


\section{LIST OF FIGURES}

Figure

1.1

1.2

1.3

1.4

1.5

1.6

1.7

4.4.1

4.4 .2

4.4 .3

5.1
Title

Page

Map of Appalachia 5

County Economic Levels in Appalachia, 2002

6

County Economic Levels in Appalachia, 2008

7

Self-employment per 1000 Labor Force, 1995

14

Self-employment per 1000 Labor Force, 2005

14

Firm Births per 1000 Labor Force, 1998

15

Firm Births per 1000 Labor Force, 2005

15

Change in Population, 1995-2005

56

Change in Employment, 1995-2005

57

Change in Per Capita Income, 1995-2005

57

68 


\section{CHAPTER 1 \\ INTRODUCTION}

\subsection{INTRODUCTION AND PROBLEM STATEMENT}

Increasing uncertainty in the world economy has created challenges for regions to pursue development strategies to achieve economic growth. Globalization, increased marketing integration, and the advent of new technologies led to approaches from traditional industrial recruiting to less traditional approaches. Among these latter approaches is the increased importance of entrepreneurship for creating economic growth through establishment of new firms or growth from established firms. New businesses and self employment contribute new jobs at the start of the business operation, result in higher income levels and increased wealth, and later improve market competition as new firm formation increases in the industry (Fritsch and Mueller, 2004; Henderson, 2006). With new business formations and the growth of existing ones, the most obvious contribution of entrepreneurship to increased welfare in the society is the creation of new jobs and additional income due to multiplier effects (Robinson, Dassie, and Christy, 2004). Entrepreneurs create new wealth for themselves and to the communities by taking innovations to the market and commercializing new ideas. Many scholars and professionals believe that entrepreneurship is critical to maintain an economy's health and that business creation in low income areas is essential for economic development (Goetz and Freshwater, 2001; Acs, 2006; Lichtenstein and Lyons, 2001; Smilor, 1997). As Minniti (1999) argues, entrepreneurs are catalysts for economic growth as they generate a networking innovation that promotes the creation of new ideas and new market formations. Schumpeter (1934) also states that the success of markets lies in the spirits of entrepreneurs who persist in developing new products and technologies and succeed, ultimately, resulting in lower production costs. He also described five 
cases in which innovative activity increases economic growth. First is the introduction of a new good, which is a new product or an improvement of a product which is not yet known by the consumers in the market; a new method of production, the one that is not yet used in the manufacturing of the product; a new market that has not been entered for a particular product; a new source of supply for raw materials whether it already exists and is eventually discovered or it has to be created; and the evolution of a new organization in an industry like the formation of a monopoly. According to Schumpeter, these activities result in economic opportunities which eventually lead to economic growth. In addition, the works of entrepreneurs lead to more innovations and more profit opportunities and, hence, more growth which becomes a cycle of economic opportunities and for maximizing profit.

Wennekers and Thurik (1999) summarized the influence of entrepreneurship on regional economic growth in two ways. First, entrepreneurship increases the start-up rate of new firms and therefore increases employment. Second, entrepreneurial activities yield efficiency advantages within the existing firms. These result in a social structure that influences the absorptive capacity of a country and promote its ability to adopt new technologies. Hence, when entrepreneurs reap the benefits of their abilities, within the firm and in relation to other firms, their activities are likely to enhance economic growth and development.

Over the years, policymakers have shown great interest in exploring the role of entrepreneurship in generating economic growth and development. Kreft and Sobel (2005) state that economic development policies in the past two decades have been diverted from attracting large manufacturing firms towards encouraging internal entrepreneurship. Understanding economic development and identifying appropriate policies to foster development requires an understanding of entrepreneurship in a particular environment. In this era of globalization, 
supporting entrepreneurship becomes indispensable for the United States to regain a competitive lead in the world economy (Baumol, Litan, and Schramm, 2007). An understanding of entrepreneurship becomes important to know how entrepreneurship matters in economic growth and development, and furthermore, how entrepreneurial capacity can be expanded to increase the chance of achieving economic development. Exploring the characteristics of entrepreneurship and its contributions to the local economy can help develop a map for designing specific development policies for Appalachia. The target of these policies is to improve and expand community-based economic development capabilities and initiatives to assist small towns and rural areas in creating new firms, retaining and expanding local businesses, and expanding entrepreneurial development, and eventually helping to alleviate poverty.

Understanding the relationship between entrepreneurship and economic development is crucial for two reasons. First, the international economic development community has learned that the one-size-fits-all approach does not work (Easterly, 2001). Second, economic importance of entrepreneurship and its role in economic development has received significant emphasis in research work in recent years. This suggests that public policy needs to emphasize the dynamics of entrepreneurship and economic development as well as relevant local institutional conditions and region-specific characteristics.

Though considerable attention has been given to examining the links between entrepreneurship and economic development, the central focus of this study is to determine the importance of entrepreneurship in economic development on a regional perspective, specifically in the Appalachian region. The Appalachian region has been considered by many studies as an area symbolized by underdevelopment and poverty (Pollard, 2003). Forty-two percent of the population is in rural areas compared to the national average of twenty percent. In addition, 
many parts of the region can be considered remote due to poor infrastructure and topography. Median family income in Appalachia remains substantially below the national average. The poverty rate is higher and labor force participation is lower in the region compared to the United States as a whole. For instance, the poverty rate in the US was 13.2 percent in 1990 and 12.4 percent in 2000. In Appalachia, the poverty rate was from 15.4 percent in 1990 to 13.6 percent in 2000 (US Census). Moreover, the region was concluded to be different from the other parts of the US not only because of its geographical location but because of its social and economic development status relative to the other regions of the country (Isserman, 1996). Therefore, there is a need to determine how entrepreneurship contributes to the well-being of the economy for policy makers to develop appropriate policies to improve the Appalachian environment for business formation that leads to economic development. This study will provide evidence as to whether entrepreneurship contributes to regional economic development. The main objective of this study is to increase the understanding of entrepreneurship, its contributions to economic growth, and its potential as a development strategy for a region characterized by poverty and underdevelopment such as Appalachia.

\subsection{THE STUDY AREA}

The study area comprises the Appalachian region where the relationship between entrepreneurship and economic development is examined. The region, as defined by the Appalachian Regional Commission (ARC), is composed of 13 states with a total of 410 counties as shown in Figure 1. The area includes the whole state of West Virginia, most of Pennsylvania, the southern part of New York, southeastern Ohio, the western portions of Maryland, South 
Carolina and North Carolina, the eastern portions of Kentucky and Tennessee, the northern areas of Alabama and Georgia, and the northeastern part of Mississippi.

Figure 1. Map of Appalachia

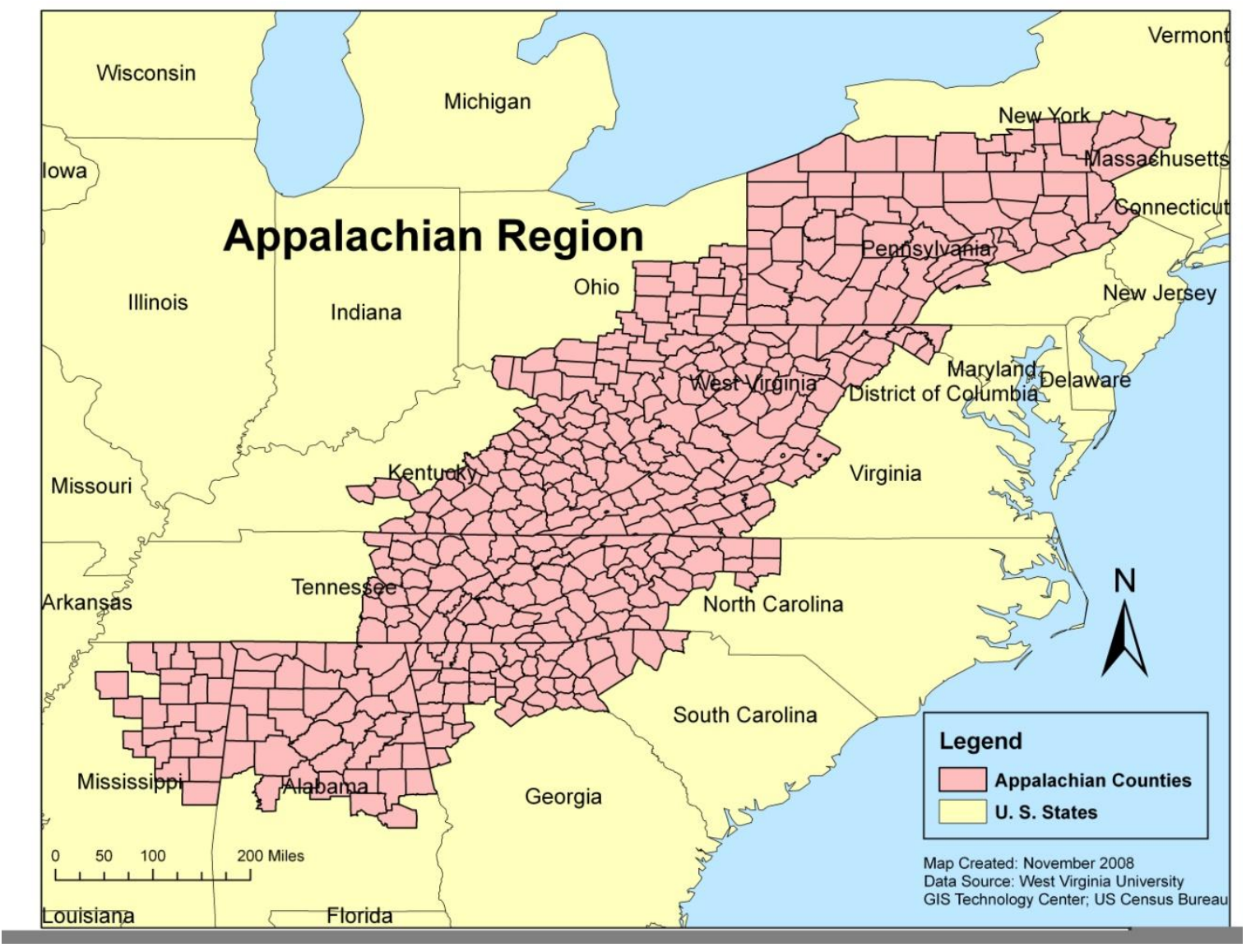

The region has received considerable attention in the literature as it is recognized as having unique characteristics particularly with respect to its economic situation relative to the other parts of the US. The region's economy in the past was based on manufacturing, agriculture, and the extraction of natural resources, while it is now diversifying into services, retailing, and tourism (Appalachian Regional Commission, 2008). Considering the economic diversity of the region, the commission has developed a classification system that identifies and monitors the economic status of its counties. The system involves an index of county economic 
status based on economic indicators including unemployment rate, poverty rate, and per capita income. Using the composite index value, each county is classified into one of five categories of economic status: distressed, at-risk, transitional, competitive, and attainment. Distressed counties are the most economically depressed counties; at-risk are those at risk of becoming economically distressed; transitional are those transitioning between weak and strong economies; competitive are those who can compete in the national economy, but are not at the top levels of economic status; and attainment are the ones which are economically strongest. As shown in Figures 1.2 and 1.3, distressed counties are mostly in central Appalachia. However, between 2002 and 2008, some counties in central Appalachia attained the "at-risk" category. The northern part of Appalachia was mostly in the transitional category between 2002 and 2008 while the southern portion shows diverse changes.

Figure 1.2 County Economic Levels in Appalachia, 2002

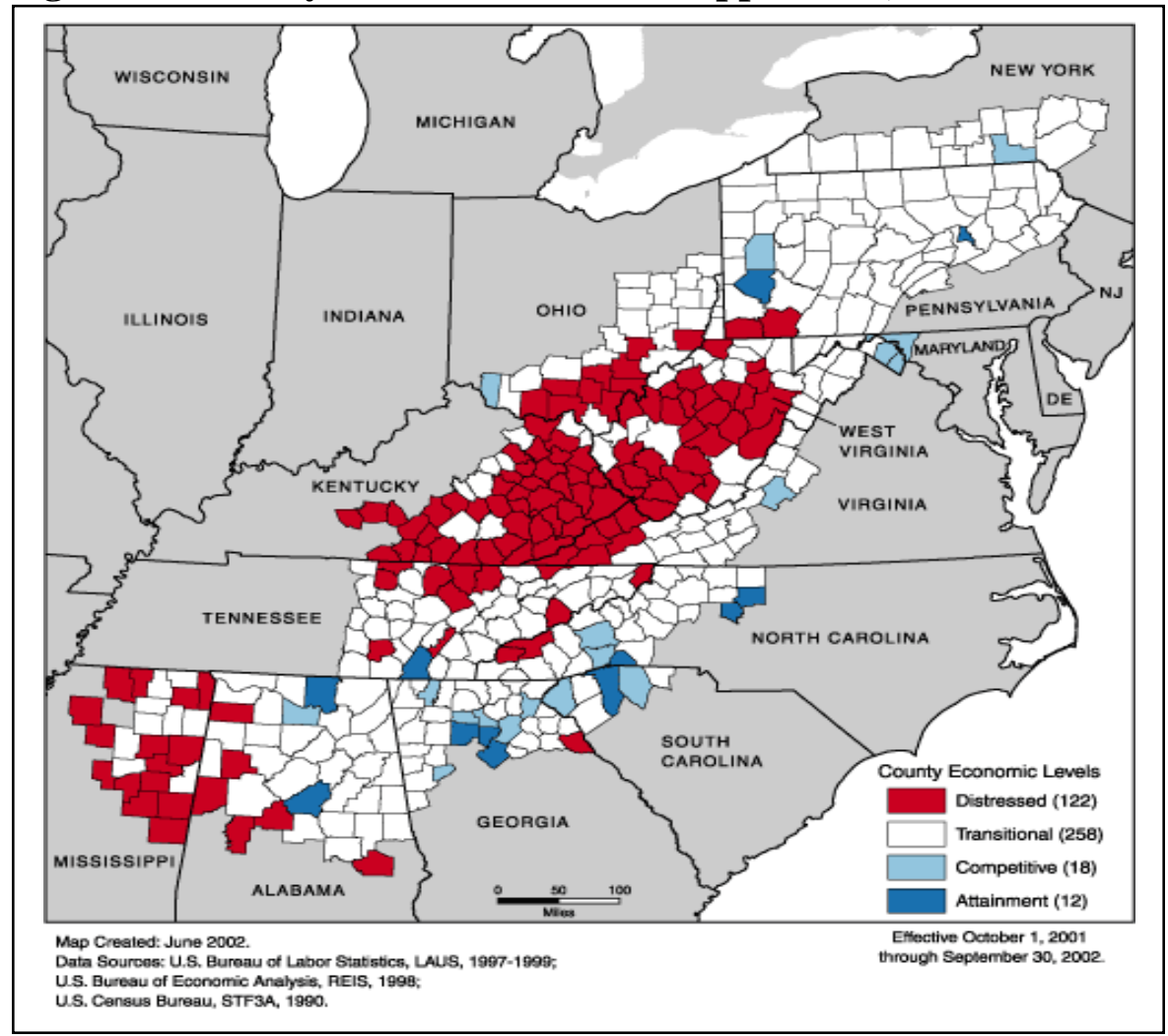

Source: Appalachian Regional Commission, 2008 
Figure 1.3 County Economic Levels in Appalachia, 2008

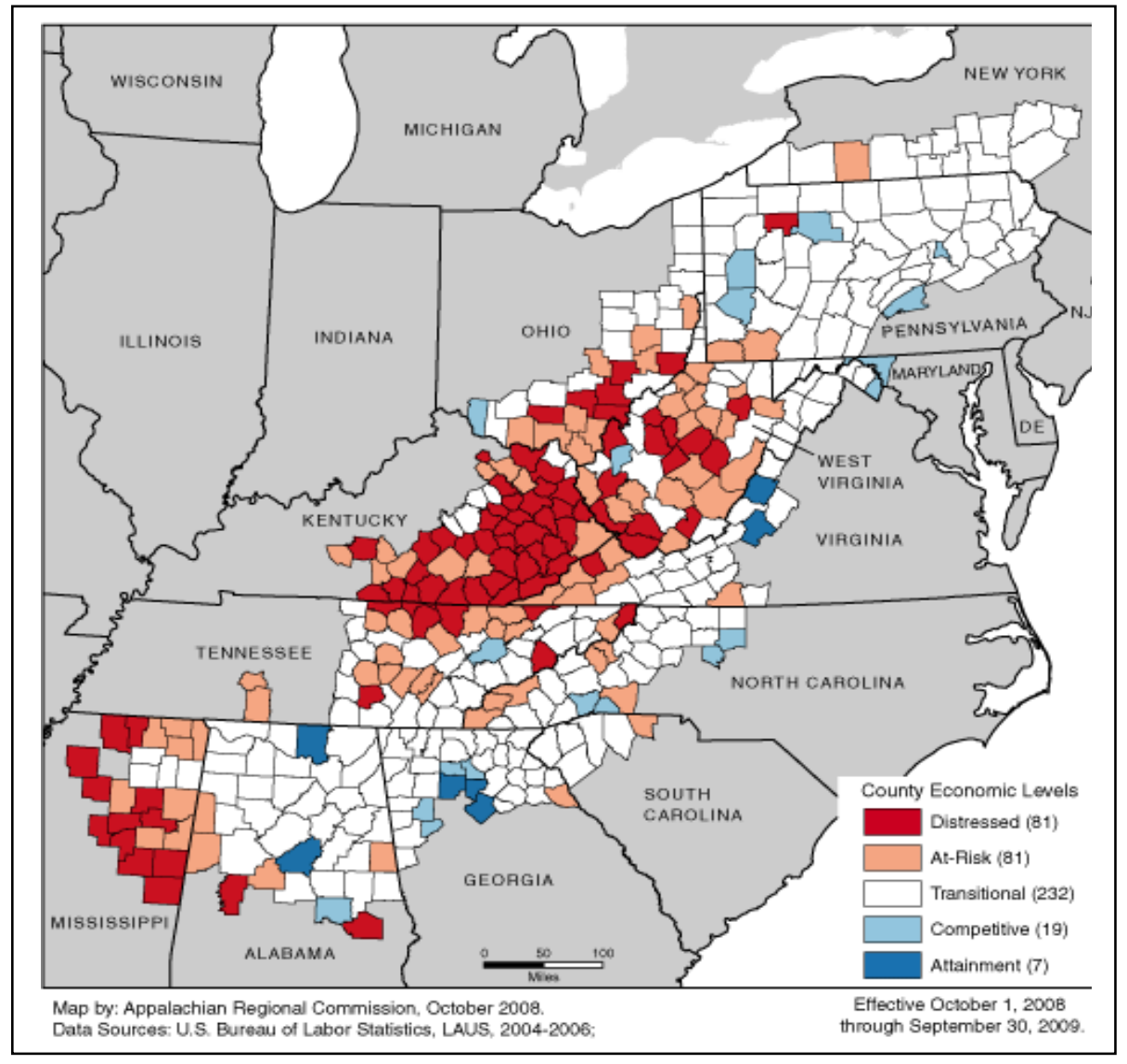

Source: Appalachian Regional Commission, www.arc.gov

Appalachia is chosen considering its economic situation compared to other regions in the country. It has a number of rural states that could show evidence of the effectiveness of supporting entrepreneurship as a development strategy in areas with rural characteristics. The variability in economic status across the region provides variation in data which should enable a viable quantitative analysis leading to the identification of valuable econometric relationships between variables in the model.

In terms of entrepreneurship, despite the region's geographical and economic disadvantages, Appalachia has many entrepreneurial assets including small, home-grown businesses that play an important role in creating self-sustaining local economies and improving 
quality of life. The Appalachian Regional Commission (ARC) started an Entrepreneurial Initiative with the goal of promoting the formation of businesses owned by local residents to increase local wealth and provide employment opportunities to the local community. Figures 1.4 and 1.5, constructed using data from the Bureau of Economic Analysis (BEA), present the variation in the numbers of self-employed throughout the Appalachia for years 1995 and 2005. Self-employment is one of the most popular measures of entrepreneurship used in the literature. The maps show the heterogeneity of entrepreneurial capacity in the region for the years covered in the data which facilitates the econometric analyses of the data. Counties with higher levels of entrepreneurial capacity are expected to have higher levels of growth compared to the less entrepreneurial counties.

The number of firm start-ups is another popular measure of entrepreneurial activity. Figures 1.6 and 1.7 present the variation in the numbers of firm births throughout the Appalachia for years 1998 and 2005 since data on firm births in 1995 is not available. The maps are created using published data from Statistics of U.S. Businesses (U.S. Census Bureau).

In addition, Tables 1.1 to 1.5 provide the top and bottom 30 counties in Appalachia for selected measures of entrepreneurial activity. The top and bottom counties are in different geographical locations and it is important to note that every county has some level of entrepreneurial activity. A complete list of counties of Appalachia and the measures of entrepreneurial activity is presented in the Appendix. 
Table 1.1 Top and Bottom 30 Counties : Proprietors per 1000 Labor Force (1995)

\begin{tabular}{llllll}
\hline & Top 30 Counties & & \multicolumn{3}{c}{ Bottom 30 Counties } \\
\hline State & County & & State & County & \\
\hline TN & Meigs & 496.055 & AL & Macon & 76.505 \\
TN & Jackson & 429.555 & GA & Whitfield & 82.161 \\
GA & Dawson & 377.119 & SC & Cherokee & 85.171 \\
NC & Clay & 357.979 & PA & Montour & 86.302 \\
WV & Calhoun & 338.241 & MS & Lee & 92.765 \\
WV & Roane & 315.482 & KY & Boyd & 93.631 \\
TN & Grundy & 307.981 & TN & Greene & 95.580 \\
MD & Garrett & 303.909 & KY & Harlan & 99.070 \\
GA & Towns & 300.965 & VA & Highland & 100.930 \\
GA & Madison & 300.669 & AL & Marion & 101.546 \\
PA & Susquehanna & 300.615 & AL & Fayette & 102.529 \\
WV & Wirt & 294.312 & GA & Murray & 103.306 \\
PA & Pike & 287.731 & GA & Gordon & 103.771 \\
GA & Union & 287.637 & AL & Jefferson & 103.854 \\
TN & Cannon & 284.164 & MS & Lowndes & 104.129 \\
WV & Doddridge & 279.777 & WV & Cabell & 105.552 \\
PA & Perry & 279.249 & MD & Washington & 106.475 \\
GA & Paulding & 275.335 & SC & Spartanburg & 106.921 \\
PA & Sullivan & 274.029 & WV & Ohio & 107.494 \\
WV & Morgan & 271.540 & VA & Scott & 108.513 \\
GA & Cherokee & 271.438 & WV & Boone & 108.879 \\
NC & Polk & 271.055 & MS & Prentiss & 108.954 \\
GA & Fannin & 270.316 & WV & Mingo & 109.837 \\
VA & Buchanan & 269.327 & MS & Panola & 110.480 \\
TN & Fentress & 266.912 & WV & Hancock & 110.987 \\
GA & Dade & 266.823 & WV & Kanawha & 111.023 \\
NC & Stokes & 265.855 & AL & Tuscaloosa & 111.082 \\
KY & Menifee & 260.087 & WV & Mason & 111.794 \\
& & & & Wise $(+$ & \\
WV & Monroe & Viles & Norton city) & 112.177 \\
VA & Oktibbeha & 112.302 \\
\hline
\end{tabular}


Table 1.2 Top and Bottom 30 Counties: Growth in Proprietors per 1000 Labor Force (1995-2005)

\begin{tabular}{|c|c|c|c|c|c|}
\hline \multicolumn{3}{|c|}{ Top 30 Counties } & \multicolumn{3}{|c|}{ Bottom 30 Counties } \\
\hline State & County & & State & County & \\
\hline GA & Banks & 266.810 & GA & Forsyth & -164.523 \\
\hline $\mathrm{TN}$ & Clay & 256.679 & PA & Wyoming & -77.588 \\
\hline VA & Buchanan & 235.464 & WV & Ohio & -68.216 \\
\hline $\mathrm{TN}$ & Carter & 211.413 & KY & Clinton & -67.230 \\
\hline WV & Mason & 207.270 & $\mathrm{OH}$ & Harrison & -65.980 \\
\hline $\mathrm{AL}$ & Blount & 204.068 & GA & Dawson & -65.177 \\
\hline AL & Limestone & 203.231 & PA & Wayne & -60.910 \\
\hline $\mathrm{OH}$ & Carroll & 194.563 & $\mathrm{OH}$ & Perry & -59.993 \\
\hline $\mathrm{TN}$ & Morgan & 182.469 & KY & Whitley & -57.471 \\
\hline $\mathrm{TN}$ & Jackson & 180.715 & VA & Alleghany & -56.196 \\
\hline $\mathrm{OH}$ & Morgan & 180.451 & NY & Otsego & -56.055 \\
\hline GA & Catoosa & 176.138 & WV & Lincoln & -47.392 \\
\hline $\mathrm{NC}$ & Burke & 175.562 & $\mathrm{AL}$ & Marshall & -47.281 \\
\hline $\mathrm{TN}$ & Van Buren & 170.808 & $\mathrm{TN}$ & Roane & -45.936 \\
\hline $\mathrm{AL}$ & Walker & 167.332 & WV & Hancock & -40.259 \\
\hline GA & Paulding & 167.032 & GA & Gwinnett & -40.065 \\
\hline NY & Schuyler & 165.359 & KY & Perry & -37.473 \\
\hline $\mathrm{TN}$ & Cannon & 159.983 & NY & Tioga & -35.460 \\
\hline PA & Montour & 157.383 & WV & Taylor & -34.061 \\
\hline KY & Knox & 155.552 & WV & Wayne & -31.638 \\
\hline $\mathrm{TN}$ & Grundy & 152.632 & $\mathrm{NC}$ & Swain & -31.467 \\
\hline $\mathrm{OH}$ & Brown & 150.607 & WV & Lewis & -31.314 \\
\hline KY & Garrard & 147.366 & KY & Lawrence & -30.945 \\
\hline WV & Brooke & 144.914 & $\mathrm{NC}$ & Mitchell & -29.065 \\
\hline $\mathrm{TN}$ & Bledsoe & 143.171 & GA & Jackson & -28.729 \\
\hline $\mathrm{OH}$ & Coshocton & 141.907 & VA & Floyd & -28.045 \\
\hline $\mathrm{TN}$ & Marion & 140.492 & WV & Clay & -27.066 \\
\hline GA & Fannin & 139.520 & $\mathrm{OH}$ & Noble & -26.795 \\
\hline $\mathrm{OH}$ & Monroe & 135.686 & VA & Wythe & -26.358 \\
\hline $\mathrm{NC}$ & Avery & 135.248 & PA & Venango & -26.312 \\
\hline
\end{tabular}


Table 1.3 Top and Bottom 30 Counties: Firm Births per 1000 Labor Force (1998)

\begin{tabular}{llllll}
\hline & Top 30 Counties & \multicolumn{4}{c}{ Bottom 30 Counties } \\
\hline State & County & & State & County & \\
\hline VA & Buchanan & 44.888 & VA & Highland & 0.376 \\
VA & Giles & 20.864 & VA & Rockbridge & 0.739 \\
VA & Montgomery & 19.265 & VA & Craig & 1.078 \\
GA & Dawson & 19.068 & VA & Bland & 1.121 \\
GA & Cherokee & 12.851 & TN & Meigs & 1.479 \\
GA & Forsyth & 10.933 & VA & Grayson & 1.646 \\
GA & Towns & 10.822 & VA & Alleghany & 1.656 \\
GA & Union & 10.798 & PA & Montour & 1.770 \\
GA & Paulding & 10.323 & OH & Noble & 1.863 \\
AL & St. Clair & 9.649 & PA & Crawford & 1.932 \\
GA & White & 9.638 & OH & Morgan & 2.056 \\
VA & Carroll & 9.592 & VA & Wise & 2.089 \\
WV & Wirt & 9.259 & MS & Kemper & 2.090 \\
GA & Douglas & 8.779 & AL & Macon & 2.107 \\
GA & Gwinnett & 8.698 & TN & Jackson & 2.233 \\
PA & Elk & 8.546 & VA & Tazewell & 2.265 \\
GA & Pickens & 8.327 & VA & Dickenson & 2.401 \\
NC & Madison & 8.251 & WV & Pleasants & 2.486 \\
WV & Clay & 8.200 & KY & Lewis & 2.515 \\
WV & Webster & 8.173 & PA & Warren & 2.521 \\
NC & Polk & 7.772 & NY & Chemung & 2.537 \\
PA & Wayne & 7.720 & WV & Tucker & 2.546 \\
GA & Lumpkin & 7.624 & WV & Hancock & 2.553 \\
GA & Fannin & 7.513 & NY & Tompkins & 2.590 \\
GA & Rabun & 7.504 & TN & Pickett & 2.596 \\
KY & Martin & 7.489 & AL & Clay & 2.603 \\
NC & Clay & 7.360 & KY & Elliott & 2.644 \\
Chilton & 7.328 & WV & Hardy & 2.646 \\
Washington & 7.263 & NY & Steuben & 2.671 \\
NA & 7.117 & WV & Roane & 2.686 \\
\hline
\end{tabular}


Table 1.4 Top and Bottom 30 Counties: Growth in Firm Births per 1000 Labor Force (1998-2005)

\begin{tabular}{|c|c|c|c|c|c|}
\hline \multicolumn{3}{|c|}{ Top 30 Counties } & \multicolumn{3}{|c|}{ Bottom 30 Counties } \\
\hline State & County & & State & County & \\
\hline KY & Madison & 27.010 & VA & Buchanan & -20.936 \\
\hline $\mathrm{AL}$ & Shelby & 17.022 & GA & Dawson & -10.531 \\
\hline WV & Marion & 14.818 & $\mathrm{AL}$ & St. Clair & -8.093 \\
\hline VA & Alleghany & 4.949 & $\mathrm{NC}$ & Madison & -5.998 \\
\hline VA & Bath & 3.843 & WV & Wirt & -5.867 \\
\hline $\mathrm{NC}$ & Clay & 3.802 & PA & Elk & -4.932 \\
\hline $\mathrm{NC}$ & Macon & 3.651 & KY & Magoffin & -4.808 \\
\hline $\mathrm{NC}$ & McDowell & 3.205 & GA & Paulding & -4.609 \\
\hline KY & Lee & 2.974 & KY & Martin & -4.251 \\
\hline $\mathrm{TN}$ & McMinn & 2.935 & WV & Clay & -4.067 \\
\hline $\mathrm{OH}$ & Morgan & 2.330 & GA & Towns & -4.027 \\
\hline VA & Floyd & 2.178 & GA & Union & -3.782 \\
\hline KY & Wolfe & 2.158 & GA & Cherokee & -3.542 \\
\hline PA & Sullivan & 2.031 & GA & Douglas & -3.513 \\
\hline KY & Owsley & 2.031 & WV & Braxton & -3.407 \\
\hline KY & Edmonson & 2.025 & WV & Nicholas & -3.141 \\
\hline WV & Hancock & 1.813 & MS & Choctaw & -3.131 \\
\hline PA & Wyoming & 1.784 & $\mathrm{AL}$ & Blount & -2.923 \\
\hline GA & Stephens & 1.775 & WV & Barbour & -2.891 \\
\hline $\mathrm{OH}$ & Noble & 1.687 & GA & White & -2.888 \\
\hline KY & Lewis & 1.622 & $\mathrm{OH}$ & Brown & -2.856 \\
\hline $\mathrm{KY}$ & Fleming & 1.607 & GA & Banks & -2.685 \\
\hline WV & Roane & 1.590 & GA & Dade & -2.671 \\
\hline $\mathrm{TN}$ & Pickett & 1.557 & WV & Mason & -2.616 \\
\hline WV & Gilmer & 1.533 & $\mathrm{AL}$ & Chilton & -2.516 \\
\hline KY & Cumberland & 1.522 & WV & Calhoun & -2.466 \\
\hline MS & Kemper & 1.510 & $\mathrm{TN}$ & Cumberland & -2.384 \\
\hline PA & Cameron & 1.468 & WV & Webster & -2.382 \\
\hline WV & Summers & 1.397 & $\mathrm{OH}$ & Hocking & -2.360 \\
\hline WV & Jefferson & 1.323 & WV & Marshall & -2.352 \\
\hline
\end{tabular}


Table 1.5 Top and Bottom 30 Counties: Firm Deaths per 1000 Labor Force (1998)

\begin{tabular}{|c|c|c|c|c|c|}
\hline \multicolumn{3}{|c|}{ Top 30 Counties } & \multicolumn{3}{|c|}{ Bottom 30 Counties } \\
\hline State & County & & State & County & \\
\hline PA & Allegheny & 0.161 & VA & Buchanan & 46.707 \\
\hline VA & Highland & 0.372 & KY & Madison & 26.045 \\
\hline VA & Bland & 0.593 & VA & Giles & 22.510 \\
\hline KY & Magoffin & 0.702 & VA & Montgomery & 20.428 \\
\hline $\mathrm{TN}$ & Macon & 0.931 & WV & Marion & 18.939 \\
\hline VA & Craig & 1.152 & $\mathrm{AL}$ & Shelby & 15.260 \\
\hline VA & Rockbridge & 1.350 & WV & Mingo & 9.651 \\
\hline AL & St. Clair & 1.556 & $\mathrm{NC}$ & McDowell & 8.497 \\
\hline $\mathrm{NC}$ & Madison & 1.559 & KY & Leslie & 8.457 \\
\hline $\mathrm{OH}$ & Holmes & 1.717 & WV & Webster & 7.924 \\
\hline WV & Mason & 1.775 & VA & Carroll & 7.840 \\
\hline $\mathrm{TN}$ & Cannon & 1.787 & WV & Nicholas & 7.297 \\
\hline WV & Doddridge & 1.849 & $\mathrm{AL}$ & Coosa & 7.134 \\
\hline $\mathrm{TN}$ & Clay & 1.873 & GA & Madison & 7.008 \\
\hline KY & Green & 1.886 & WV & Logan & 6.734 \\
\hline $\mathrm{OH}$ & Morgan & 1.907 & MS & Montgomery & 6.507 \\
\hline KY & Rockcastle & 1.932 & $\mathrm{OH}$ & Harrison & 6.472 \\
\hline $\mathrm{TN}$ & Jackson & 2.027 & $\mathrm{AL}$ & Chilton & 6.340 \\
\hline WV & Marshall & 2.089 & WV & Lincoln & 6.309 \\
\hline KY & Casey & 2.142 & MS & Calhoun & 6.265 \\
\hline $\mathrm{OH}$ & Pike & 2.152 & MS & Tishomingo & 6.263 \\
\hline $\mathrm{NC}$ & Burke & 2.169 & WV & Clay & 6.200 \\
\hline $\mathrm{NC}$ & Yancey & 2.203 & WV & Tyler & 6.184 \\
\hline VA & Grayson & 2.236 & $\mathrm{NC}$ & Polk & 6.182 \\
\hline VA & Tazewell & 2.287 & MS & Benton & 6.173 \\
\hline NY & Schuyler & 2.292 & $\mathrm{TN}$ & McMinn & 6.122 \\
\hline KY & McCreary & 2.296 & KY & Harlan & 6.065 \\
\hline WV & Pleasants & 2.304 & MS & Prentiss & 6.039 \\
\hline PA & Greene & 2.313 & VA & Botetourt & 5.941 \\
\hline $\mathrm{OH}$ & Carroll & 2.317 & PA & Wayne & 5.878 \\
\hline
\end{tabular}


Figure 1.4

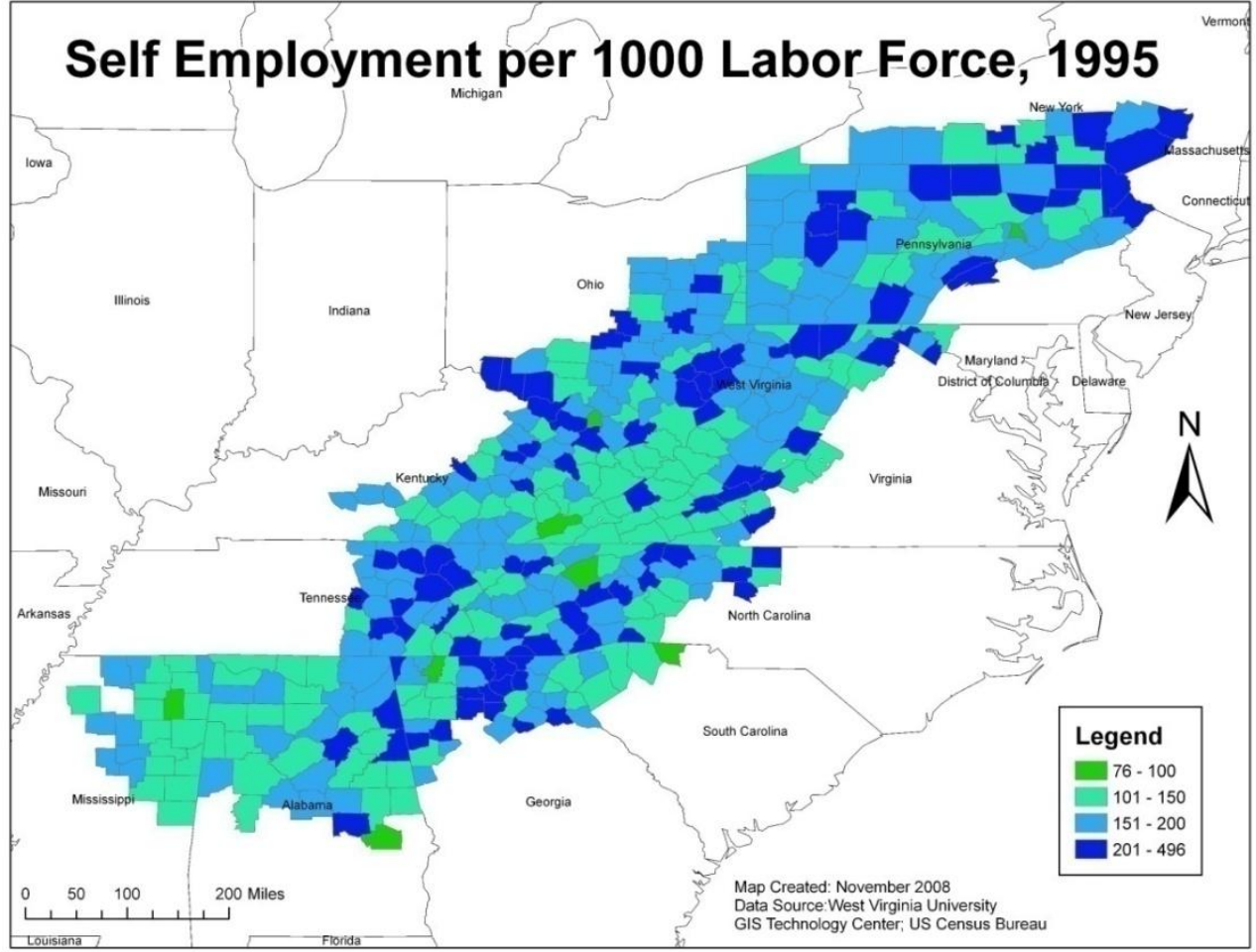

Map Created by the author

Figure 1.5

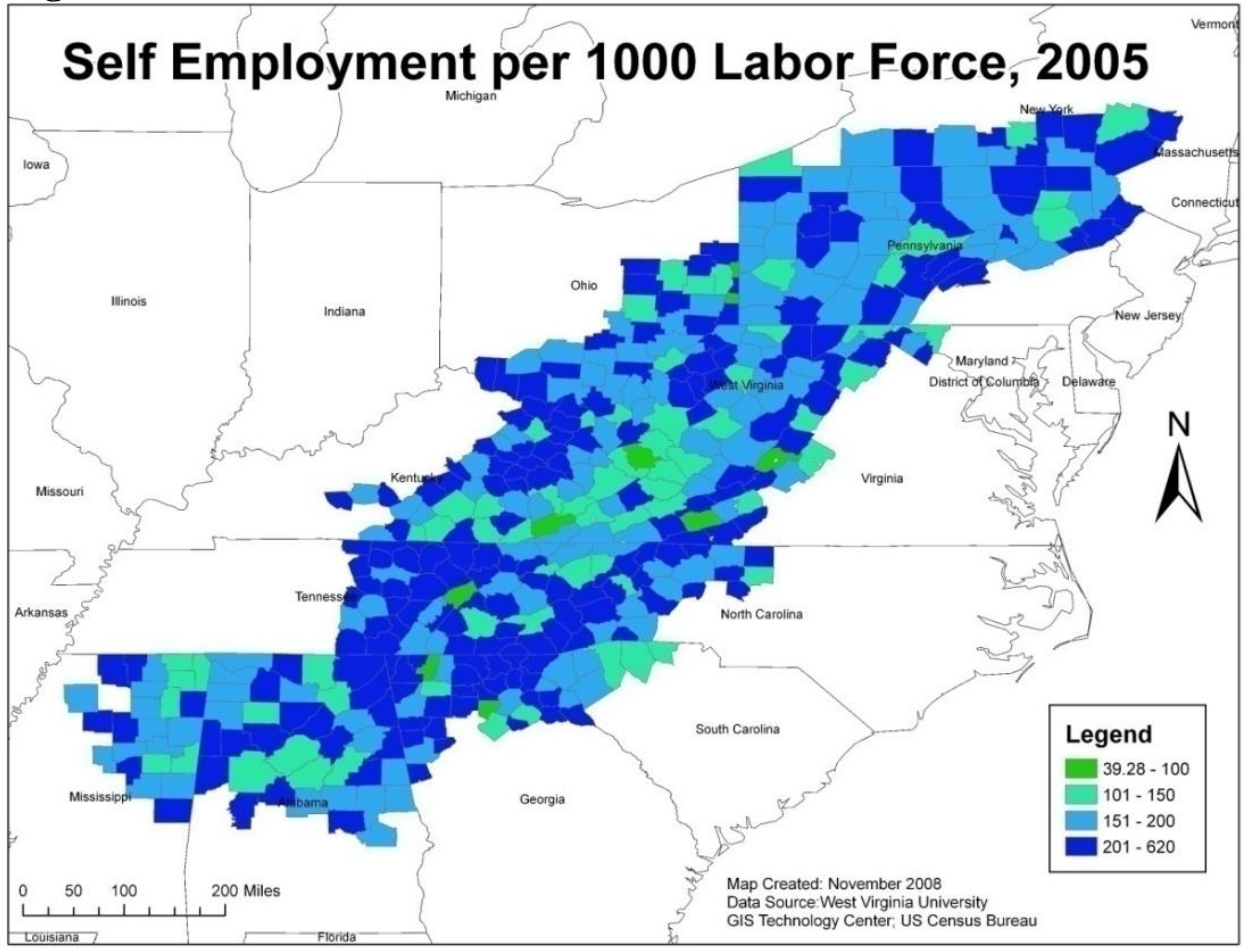

Map Created by the author 
Figure 1.6

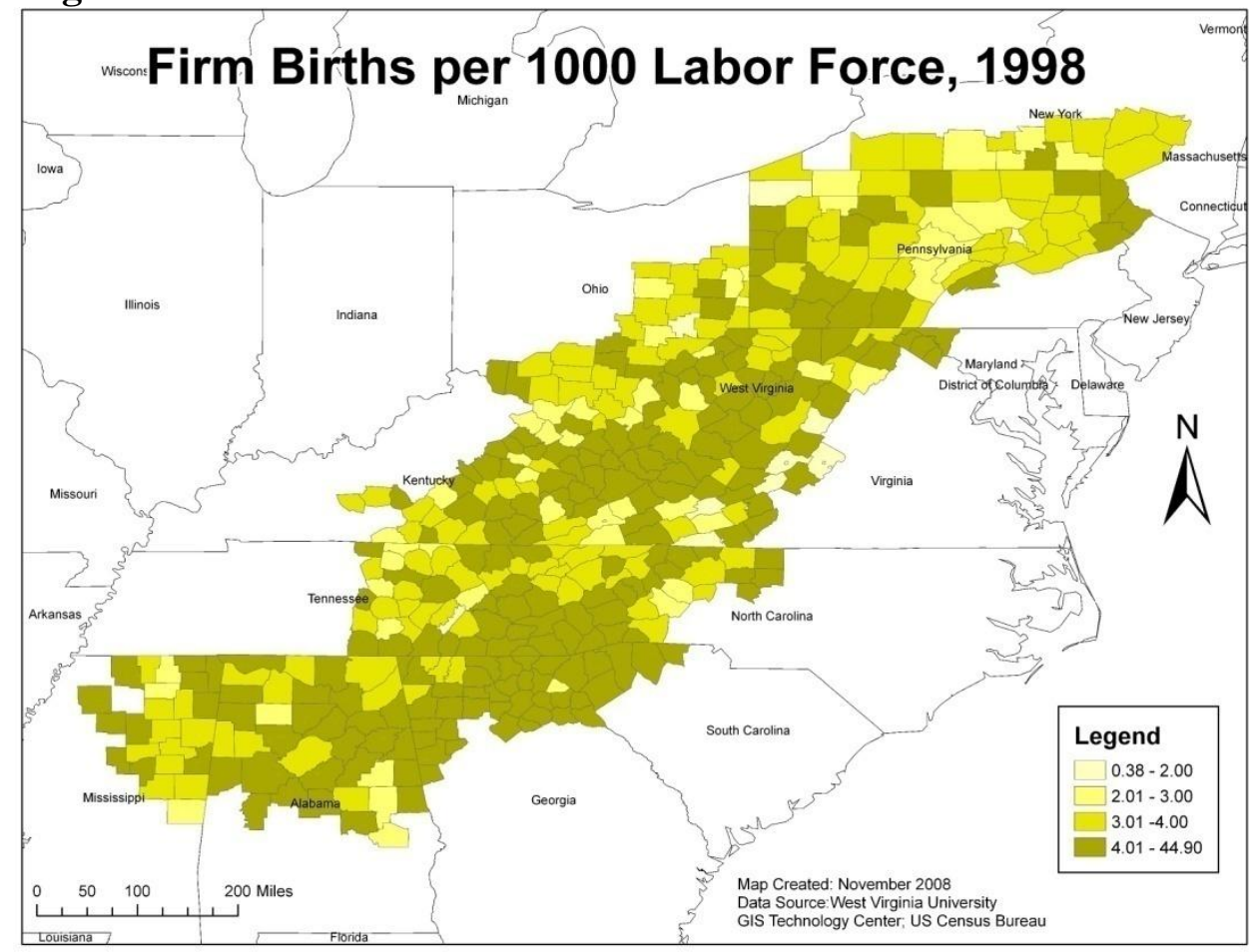

Map Created by the author

\section{Figure 1.7}

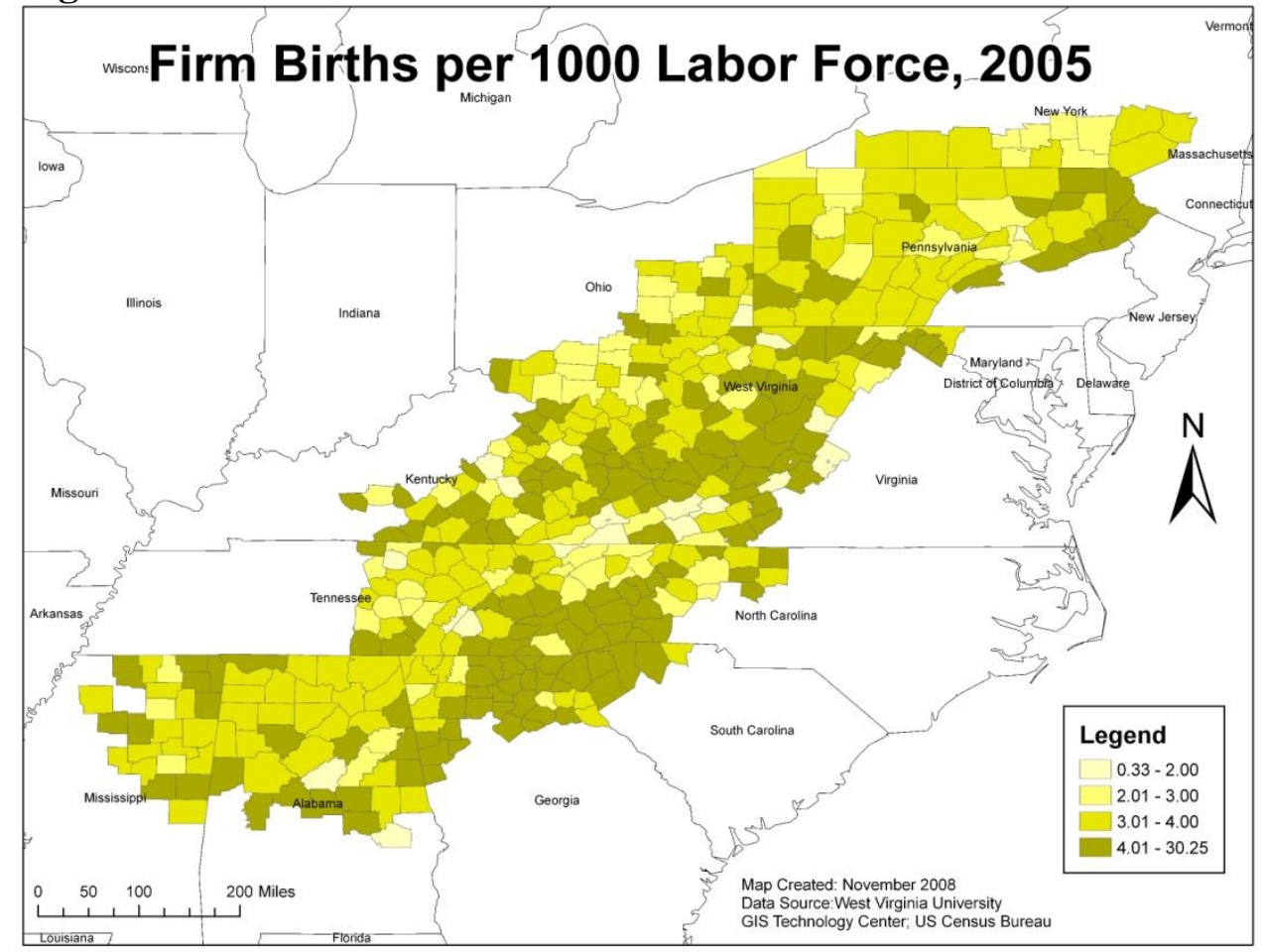

Map Created by the author 


\subsection{OBJECTIVES OF THE STUDY}

The main objective of the study is to determine the role of entrepreneurship in economic development in the Appalachian region. Specifically, the objectives are:

1. To develop a data base of the socio-demographic, entrepreneurial, and economic variables for Appalachia;

2. To determine the impact of entrepreneurship on regional economic growth and development in the Appalachian region.

3. Based on the research findings, develop policy alternatives for regional economic development.

\subsection{ORGANIZATION OF THE STUDY}

This study is composed of six chapters. Chapter 1 is the introductory part discussing the background of the study. Chapter 2 deals with the literature review on link between entrepreneurship and economic development, defining entrepreneurship, measures of entrepreneurship, and modeling techniques. Chapter 3 provides the theoretical foundations and Chapter 4 is a discussion of the model and data. Results of model estimation and discussions on the role of entrepreneurship in economic development are presented in Chapter 5. Finally, Chapter 6 provides a summary of findings, conclusions, policy implications, and recommendations for future studies. 


\section{CHAPTER 2}

\section{LITERATURE REVIEW}

\subsection{ENTREPRENEURSHIP AND ECONOMIC GROWTH}

Although empirical research on the role of entrepreneurship is not well-developed, the literature has paid considerable attention to the link between entrepreneurship and economic growth. The first issue in examining the relationship between entrepreneurship and economic growth is the definition of the term "entrepreneurship." Since entrepreneurship is a multidimensional concept and there is no general agreement on an economic theory of entrepreneurship, previous studies have defined and used the term in different ways. Beginning with Schumpeter (1934) an "entrepreneur" is an individual marked with innovative ideas, utilizing new combinations of means of production. Kirzner (1979) emphasized the entrepreneur as an enthusiast in discovering opportunities to make profit. Knight (1921) and Schultz (1980), supporting neo-classical economic theory, described an entrepreneur as an individual who is willing to take risks in performing economic functions, while others (Hagen, 1962; McClelland, 1961; Kihlstrom and Laffont, 1979) argued that an entrepreneur is a person with certain unique psychological characteristics. Although these concepts have contributed greatly to the understanding of entrepreneurship, a universally accepted explanation or measure of the concept has not yet been found. Hence, previous studies have used different concepts according to the purpose of the study, the theory applied, and the availability of information needed for empirical research.

To investigate the link between entrepreneurship and economic growth, Wennekers and Thurik (1999) presented a framework consisting of three parts as a starting point in the field of 
studying entrepreneurship and economic development. Using theories developed in previous studies on the subject, they argued that the beginning of entrepreneurship is about the characteristics and roles of individuals and the typology of entrepreneurship should start at the micro level. Entrepreneurship takes place in the firm where the entrepreneur transforms his personal traits, attitudes and skills into actions. These actions at the firm level are reflected through "newness" by new products, innovations, and entry to new markets or business start-ups. At the aggregate level, these many entrepreneurs create variety in the industries, regions, and national economies and through competition lead to survival of the most viable firms and industries. This process then transforms the regional and national economies by replacing obsolete firms with highly productive ones which eventually increase international competitiveness and increase profits. Wennekers and Thurik (1999) assumed that the result of this chain linking the entrepreneur to the national economy will be economic growth. In addition, their framework suggests that the outcome of this dynamic process depends on a set of conditions where the entrepreneur operates. These conditions refer to the cultural environment in the region and in the national economy as well as the institutional framework defining the incentives and the barriers in transforming entrepreneurial ambitions into actions. Their conclusions suggested to operate in the multidimensional concept of entrepreneurship at higher dimensions such as the industries and national economies, as well as possibly devising a scale to monitor the level of entrepreneurship over time and/or comparing entrepreneurship levels between economies. They also emphasized the conditions for entrepreneurship including cultural and institutional factors, as well as technological, demographic, and economic forces. The last part of the framework linking entrepreneurship and economic development is an attempt to answer why some new start-ups fail, what are the roles of institutions and policies in the 
performance of entrepreneurship in the national economies, and how to incorporate the results in econometric models which can be used for policy analysis.

Acs et al. (2005) used start-ups of new firms as a measure of entrepreneurship that facilitates spillover of knowledge. This is based on the theory of endogenous growth where knowledge was added as a factor explaining economic growth aside from the traditional factors of production, capital and labor. Entrepreneurship was used as a mechanism that transforms knowledge into growth. The study used a fixed effects and simultaneous equations model to empirically examine the impacts of entrepreneurship on economic growth using country-level data for years 1981-1998. The models used lagged values of Gross Domestic Product (GDP) as a measure of economic growth regressed against variables explaining economic growth such as investments in knowledge, level of entrepreneurship, and a set of other variables. The level of entrepreneurship was represented by using the self-employment rate and was found to have a positive impact on economic growth in both models. Countries with higher degrees of entrepreneurial activity were found to have higher rates of economic growth.

Another cross-country analysis was performed by Beck, Demirguc-Kunt, and Levine (2005) who found a positive and statistically significant relationship between small and medium enterprises (SMEs) and economic growth. SMEs are found to have high levels of innovation in skill intensive industries (Acs and Audretsch, 1987) and are used to measure entrepreneurial levels in the literature. The study used a database on the share of SME labor in the total manufacturing sector of the countries as a variable to explain economic growth measured by real GDP per capita. Several policy variables were included in the growth model such as government expenditures as a share of GDP, share of exports and imports in GDP, inflation rate, share of credit to the private sector by financial institutions in GDP, and variables measuring business 
environment. Using ordinary least squares (OLS) regression, the results revealed that the share of SME employment in total manufacturing employment is associated with greater levels of growth in GDP per capita. To control for endogeneity, a second model using instrumental variables (IVs) was employed. Though the result yielded a positive relationship between SMEs and GDP per capita, it was not statistically significant.

Audretsch and Keilbach (2005) introduced the concept of entrepreneurship capital, referring to the society's capacity to create entrepreneurial activity specifically to generate new firms. The study hypothesized that a region with more entrepreneurship capital shows a higher economic performance. This is based on the theory of entrepreneurship serving as a mechanism to transform knowledge spillovers to economic growth. Specifically, the study measured the impact of entrepreneurship on regional labor productivity and on the regional growth of labor productivity in Germany. Entrepreneurship capital was measured using the number of startup enterprises relative to the region's population. In addition, entrepreneurship capital was classified into three types: startups in all industries, high-technology startups, and startups in Information Communication and Technology (ICT) industries. This was done to capture the effects of the two latter measures on economic performance since they involve R\&D as well as greater financial risks. The results of the regression revealed that all three measures of entrepreneurship capital significantly affect the region's labor productivity. However, the results for the second model on the effect of entrepreneurship capital on the growth of labor productivity showed statistically significant effects only on the R\&D intensive industries.

Acs and Armington (2005) also examined the relationship between entrepreneurship and economic growth, using the Census Business Information Tracking Series (BITS) dataset. These data cover US private sector businesses and track their employment and firm ownership. They 
were used to estimate a regression model of regional variation in rates of employment growth as determined by entrepreneurship. Economic growth was represented by average annual employment growth while entrepreneurial activity was measured using the formation rate of firms with less than 500 employees and the business-owner share of the labor force. In addition, measures of agglomeration effects and human capital were included in the model. As hypothesized, the results revealed a positive and statistically significant coefficient on the firm birth rate. Business-owner share of the labor force was also found to make a positive and statistically significant contribution to employment growth. Specifically, the study reported that an increase in the new firm formation rate of one standard deviation from its mean causes the employment growth rate to increase by one-half standard deviation from its mean.

Van Stel and Suddle (2005) used regional data in the Netherlands to examine the relationship between new firm formation and change in regional employment. In addition, they investigated the relationship considering the difference in time period, sector, and degree of urbanization. They found that the maximum effect of new firms on regional development is reached after about six years. Fixed effects estimation was employed using employment growth as the dependent variable regressed against startup rate, wage growth, and population density. To control for differences in time periods, the sample was divided into two time periods and the results showed that the impact of new firm formation to employment growth has been stable and exactly the same in both periods. Moreover, the study investigated the relationship between employment growth and startup rates across different sectors. They found that the effect of startup rate is highest in the manufacturing sector. Finally, they also found that the degree of urbanization significantly affects the growth of employment. The effect of startup rate was 
bigger in the Western side compared to the Northern provinces where the average degree of urbanization is 51 percent and 12 percent, respectively.

Another study which used employment as the dependent variable was done by Folster (2000) utilizing simultaneous equations to determine whether entrepreneurs create jobs. The first equation captures the individual's choice to pursue self-employment due to a fall in employment or as a result of demand fluctuation in the market and structural changes in business conditions. The second equation represented demand for labor as a function of wage rate, business environment, and the share of self-employed. The data set is a pooled time-series cross section data on 24 Swedish counties for years 1976 to 1995 . Simultaneity issues between selfemployment and total employment was addressed by employing instrumental variables and estimating the equations using 2-stage least squares regression. Results show a statistically significant and positive relationship between self-employment and total employment.

Using 54 European regions, Beugelsdijk and Noorderhaven (2004) empirically estimated the relationship between entrepreneurial attitude and economic growth. This is based on Wennekers and Thurik's (1999) summary of the influence of entrepreneurial activity on regional economic growth that when entrepreneurs benefit from their actions, the result is enhanced growth at a macro level. The study used data on European Values Studies (EVS) which is a large scale, cross-national survey program on basic human values. Entrepreneurial characteristics were estimated using the answers to questions such as ascribed reasons for personal failure or success, values instilled in children, attitudes towards future developments, preference for equality versus freedom, and the attitude towards a number of social issues. The answers were used as proxies to measure need for entrepreneurial characteristics such as need for achievement, ability to control and taking risks, and an innovative attitude, while economic 
growth was measured using GDP per capita. They tested whether regions characterized as "entrepreneurial" grow faster than regions that score lower on entrepreneurial characteristics. Entrepreneurial attitude was determined by comparing the characteristics of self-employed individuals with the general population and with wage earners. The variation in entrepreneurial characteristics was found to have an important role in explaining growth differentials across the regions. High scores for entrepreneurial characteristics were correlated with high rates of regional economic growth.

Henderson (2006) also considered differences between rural and urban areas in examining the relationship between entrepreneurial activity and economic growth. Using county level data, entrepreneurship activity in the first model was represented by using business startup measures such as the number of business startups, the number of new businesses that survived five years, and the number of new business startups that survived and achieved high growth. In the second model, business ownership factors such as the average share of non-farm employment and the average annual growth rate in entrepreneurs were used as indicators of entrepreneurial activity. In addition to entrepreneurship measures, employment growth was regressed against other factors that are believed to be affecting economic growth such as transportation infrastructure, labor characteristics, agglomeration forces, natural amenities, property taxes, and regional dummy variables. The results of testing the model using business ownership variables support the notion that entrepreneurial activity positively affects employment growth. This is also true for the models using business startup indicators. However, when all three measures of business startups were tested in one model, only the coefficient for the number of new firms with high growth was found to be positive and significant. Considering the analysis between metropolitan and non-metropolitan areas, the study found that employment growth was stronger 
in metro counties in relation to the number of business startups and the number of new businesses that survived. However, there was no significant difference for the relationship between high growth business startups and employment growth between metro and non-metro counties.

Camp (2005) reported that the most entrepreneurial regions in the U.S. had 125 percent higher employment growth, 58 percent higher wage growth, and 109 percent higher productivity. The study supports the view that entrepreneurship is the link between innovation and regional economic growth and development. Regression results revealed that a four-year lag between measures of entrepreneurship and economic growth, the positive and significant coefficients for entrepreneurship activity and the high levels of expected variation in the analyses suggest that entrepreneurship is a driver of regional economic growth. Moreover, Kreft and Sobel (2005) support entrepreneurship as the "missing link" between economic freedom and economic growth. Economic freedom generates growth as it promotes entrepreneurial activity. This relationship was studied using sole proprietorship and patent activity as measures of entrepreneurship and the freedom index. The freedom index is composed of a number of public policies affecting economic freedom. The results further support entrepreneurship as a conduit towards economic growth.

These studies have supported the theory that entrepreneurship contributes positively to economic growth. However, empirical analyses examining the role of entrepreneurship in fostering economic growth at a county-level perspective are lacking, particularly for specific regions of the US. Most studies have used cross-country analysis and regions in a particular country while some recent research used labor market areas (LMAs) as the geographical unit of empirical analyses. A labor market area is a central city surrounded by counties which is 
considered to have integrated economic activities. By using county-level data in a specific region like Appalachia, this study will examine more closely the relationships between entrepreneurship and economic growth. This will investigate the impacts of entrepreneurial activity on economic progress in the Appalachian region and will verify the impacts of entrepreneurship as a strategy to achieve economic progress in communities that are continuously in search for new engines of growth. Furthermore, this study will add information to the literature on linking entrepreneurship and economic growth by employing changes in population and income levels as additional measures of economic growth. Most studies have used change in employment as endogenous variable, while country-level studies have used GDP growth. Using increases in population and per capita income will add a different dimension to measuring economic progress, in addition to employing change in employment as a measure of growth. In addition, this study will contribute to the existing literature by using different methods to empirically analyze the relationship between entrepreneurial activity and economic growth.

\subsection{DEFINING ENTREPRENEURSHIP}

Though entrepreneurship has gained significant attention in previous studies, there is no general consensus on the definition of the concept. Within the entrepreneurship literature, the definitions have been problematic and "the failure to establish definitions has disrupted the evolution of a framework for the entrepreneurship discipline" as quoted by Carland et al. (1995) which has resulted in a study of the entrepreneurial process in different approaches. In search of the meaning of entrepreneurship, Hebert and Link (1989) summarized three intellectual traditions in the conceptual development of entrepreneurship in the literature. These include the 
German tradition based on von Thünen, Schumpeter, and Baumol, the Austrian tradition of Kirzner, von Mises, and Menger, and the neo-classical tradition of Schultz, Knight, and Marshall. The Schumpeterian concept emphasized the entrepreneur as an initiator of creative destruction which is a beneficial phenomenon leading to disequilibrium. Schumpeter's theory argued that new firms with entrepreneurial characteristics displace less innovative firms which eventually results in higher economic growth (Schumpeter, 1934). On the other hand, the neoclassical tradition highlighted the entrepreneur as a leader towards equilibrium in the markets through entrepreneurial activities. The Austrian tradition stressed the abilities of the entrepreneur in perceiving profit opportunities.

The Schumpeterian tradition had the greatest impact on the economic literature. However, despite its significant influence in the field of entrepreneurship studies and its emphasis on startup enterprises, there is no generally accepted definition of entrepreneurship. Hebert and Link (1989, p.47) then proposed a "synthetic" definition of an entrepreneur as "someone who specializes in taking responsibility for and making judgmental decisions that affect the location, form, and the use of goods, resources, or institutions."

The literature has characterized the entrepreneur in many different ways. Low, Henderson, and Weiler (2005) described the entrepreneur as an individual who started his own business with several characteristics distinguishing him from other persons in the business world. These qualities include risk bearing, ability to make decisions, and being innovative. However, entrepreneurs vary in terms of their qualities measured through the impacts they make in a locality. Lifestyle entrepreneurs, referring to business starters who built businesses to achieve a certain lifestyle, mainly contribute to the region's entrepreneurial breadth by adding to the number of entrepreneurs in the region while improving local quality of life. On the other hand, 
high-value entrepreneurs focus on creating wealth, increasing profits, and adding jobs leading to economic growth. Describing these contrasting types of entrepreneurs creates a diversity of entrepreneurship.

Montanye (2006) defined entrepreneurship as "the process by which individuals acquire ownership (property rights) in economic rents of their creation." The creation and capture of economic rent are the individual's objectives, not only in business enterprise but in all aspects of life. The emphasis in the definition is in the actions of an entrepreneur generating economic rent as well as ownership interest which define entrepreneurship. Entrepreneurship, according to Montanye, is defined by the individual's objective success in acquiring property rights to some economic benefit leaving the individual better off than if he is under a system of perfect competition. The definition provides a useful basis for distinguishing theories of entrepreneurship from the many distinct variations within the economic literature and also serves as a distinguishing factor between entrepreneurship and management. The key to the definition is the holistic appreciation of entrepreneurial profit also conventionally known as economic rent. Economic rent is "that portion of a payment to an input which elicits no increase in output, that is, whose marginal product yield to the economy is zero" (Baumol, 1993). The point that is not emphasized in neoclassical economics is that unlike the incentive to produce goods and services under perfect competition, which is unaffected by the removal of economic rent, the incentive to act entrepreneurially diminishes as prospects for rent production and capture decrease. In sum, he defines entrepreneurship as "the successful creation and capture of economic rents in the face of uncertainty and scarcity, enables talented individuals to realize rewards that exceed the equilibrium level of perfect competition and so to live better than others as gauged in subjective utility terms." 
Still other authors in the literature recommend different approaches of defining an entrepreneur. Gartner (1988) in his article "Who is an 'Entrepreneur' is a Wrong Question" discussed the trait approach of defining an entrepreneur. In the trait approach, the entrepreneur is characterized to have a particular personality and a fixed state of existence. However, he concluded that this definition is inadequate and that behavioral approaches will be a more productive perspective for future research in entrepreneurship. The behavioral approach defines an entrepreneur as part of a complex process of creating an organization. This approach to the study of entrepreneurship shows the organization as the primary level of analysis and the entrepreneur is viewed in terms of his actions for the organization to come into existence. The emphasis of the behavioral approach is on what the entrepreneur does and not who the entrepreneur is. This supports Cole's behavioral viewpoint by quoting Say (1816) who defined the entrepreneur as an economic agent who "unites all means of production and who finds in the value of products which result in their employment the reconstitution of the entire capital he utilizes, and the value of the wages, the interest, and the rent which he pays, as well as profits belonging to himself" (Cole, 1946). Gartner concluded that organization creation is the idea that separates entrepreneurship from other disciplines. He believes that to truly understand entrepreneurship and in order to encourage its growth, the focus should be on the process by which organizations are created. The individual who creates the organization is the entrepreneur who takes other functions at each possible stage of the life of the organization. The entrepreneur becomes the innovator, the manager, the small business owner, the vice president, and other roles identified by a set of behaviors linking them to organization creation.

On linking entrepreneurship and economic growth, Wennekers and Thurik (1999, p. 46) defined entrepreneurship as the "ability and willingness of individuals to perceive and create new 
economic opportunities and introduce their ideas in the market, in the face of uncertainty and other obstacles, by making decisions on location, form and the use of resources and institutions." This definition takes a holistic approach of defining entrepreneurship as it considers newness, uncertainty, and the use of resources in taking the action to fulfill economic opportunities. They also emphasized that the entrepreneur is not a fixed state of existence but rather entrepreneurship is a role that individuals undertake to create organizations, a behavior to create opportunities for entrepreneurial activities.

For the purpose of this study, entrepreneurship will be viewed under the economic perspective of the Schumpeterian tradition. Wennekers and Thurik's definition of entrepreneurship will be adopted, in addition to the synthetic definition of Hebert and Link from which the discussion as well as the selection of variables for the analyses is based upon.

\subsection{MEASURING ENTREPRENEURSHIP}

To analyze the relationship between entrepreneurship and regional economic growth, it becomes necessary to first identify measures of entrepreneurship. This has challenged professionals as defining entrepreneurship has not been an easy task. There is a growing desire to understand the entrepreneurship process and the literature has shown indicators which helped researchers in quantifying entrepreneurship. Measurement is critical for comparing entrepreneurial capacities in different regions and countries and will enable policy makers to identify sound policies that work. However, the development of indicators to assist the analysis and exploration of entrepreneurship has been limited by the availability of data. Though the importance of entrepreneurship is recognized in various fields of study, the term remains illdefined and interpreted in many ways. As a result, the existing literature on entrepreneurship 
studies shows that researchers have used different variables as proxies in measuring entrepreneurship. For instance, a number of studies measured entrepreneurship activity using the number of startup businesses (Audretsch and Keilbach, 2005; Camp, 2005; van Stel and Suddle, 2005; Baptista, Escaria, and Madruga, 2005; Acs et al., 2005; and Acs and Armington, 2004). Recently, the number of startups became the most popular indicator used in measuring the level of entrepreneurship. Acs and Armington (2005) used firm formation rate and business-owner share of the labor force as indicators of entrepreneurship.

Self-employment is another popular measure of entrepreneurship used in the literature because of data availability (Acs et al., 2005; Henderson, 2006; Evans and Leighton, 1989; Folster, 2000). Other approximations of entrepreneurship include employment share of surviving young firms in the manufacturing industries (Audretsch, 1995) and share of small firms (Audretsch and Thurik, 1997; Carree and Thurik, 1998). To obtain estimates on the effects of government policies on entrepreneurship across the states of the US, Garrett and Wall (2006) defined the rate of entrepreneurship as the share of the working population (16 to 64 years) who are proprietors.

Low, Henderson, and Weiler (2005) used proxies to measure breadth and depth of entrepreneurial capacity in the US. Breadth characterizes quantity reflecting the size and variety of small businesses in a region that employ local resources, generate local income, and improve the quality of life. Entrepreneurial depth, on the other hand, measures quality which represents value created by the entrepreneurs for themselves and the local economy. Measures of entrepreneurship were used as dependent variables in regression equations to determine the factors determining entrepreneurial capacity in US counties. Entrepreneurial breadth is measured using self-employment to total employment ratio calculated by dividing the number of 
self-employed by total employment. This measure makes it possible to compare quantities of entrepreneurs in different areas with varying populations. Another measure used in the article is assessing entrepreneurial depth to gauge whether entrepreneurs add value to a region by creating wealth, income, and jobs. Average income and revenue capture were both used as measures of depth of entrepreneurship used to determine the heterogeneity of entrepreneurial depth in different regions. Average income is the ratio of proprietor income to proprietor employment in a county. As a measure of depth, it assumes that entrepreneurs with higher incomes add more value in the local economy. Revenue capture, a second measure of entrepreneurial depth, is calculated by dividing income by total sales which gives the percentage of total sales that ends up as income for the entrepreneurs. Data on nonfarm proprietor income over nonemployer receipt data were used to calculate revenue capture. It assumes that by generating more income per dollar of revenue, entrepreneurs add more value in the local economy.

Firm birth is another popular measure used to quantify entrepreneurship. One important factor in defining business births is timing - that is, whether births should be identified at the time when employees are hired or sometime before that. Another factor is whether the "employment" concept should be the basis of measuring business birth. If employment is the basis, self-employed individuals are counted as recommended by the EUROSTAT, the statistical arm of European Union. On the other hand, the Organization for Economic Cooperation and Development uses only businesses with hired employees as the basis of birth counts. In the US, the Census Bureau's Statistics of U.S. Businesses publishes data on firm births and deaths with definitions that are different than the Bureau of Labor Statistics (BLS). The Census estimates of births exclude self-employment and define births as "establishments that have zero employment in the first quarter of the initial year and positive employment in the first quarter of the 
subsequent year." However, a more precise measure is entrepreneurship rate defined as the number of business births per 1000 persons in the labor force. This also allows comparison of entrepreneurial capacities between regions. Sadeghi (2008) analyzed the merits of five possible definitions of establishment birth based on two concepts. First is establishment birth based on the first appearance in the registry and second is on the basis of positive employment reported. The first basis includes new businesses registered with positive employment for the first time while the latter includes not only births but also businesses that have not been active for more than one year but reported positive employment again in the current quarter. Sadeghi (2008) estimated alternative measures and the results were compared over time. Results showed some differences in the magnitude of births using different methods but no significant differences in the pattern of change over time. The study concluded the estimation of births of positive employment in the third month of a quarter and a zero employment in the previous four quarters as the preferred measure of births. The same estimation was done with establishment deaths and the preferred measure is the record with positive employment in the third month of a quarter followed by four consecutive quarters with zero employment during the third month. The advantages of the preferred measures include consistency with published data and symmetry in dealing with establishment births and deaths.

In an effort to come up with a more reasonable measure of entrepreneurship, Xue (2007) used a confirmatory factor analysis where entrepreneurship was treated as a latent variable, that is, a variable that is not directly observed but can be represented by a set of indirectly observed variables. He included variables such as technology patents, small business innovation rewards, venture capital disbursements, and technology firm establishments as indicators of entrepreneurship. Confirmatory factor analysis was employed to come up with an index called 
performing technology entrepreneurship index (PEI) based on the four indicators used in the analysis.

In his article "How many entrepreneurs does it take to change a nation?" Davis (2006) explained the need for measures of entrepreneurship that can be used and compared among different countries. He concluded that it is possible for all methods of measuring entrepreneurial capacity to converge into an agreed-upon method that can be used on a national basis. He suggested a Danish approach with three components including a model of framework for the entrepreneurship process; a method that permits comparisons of performance based on various measures that relate policies to factors affecting entrepreneurship; and government objectives defined in quantifiable terms. The framework is suggested as a foundation to enable development or adjustment of policies that relate to the factors affecting entrepreneurship. The model shows that market demand for goods and services interacts with the supply of ideas, skills, and capital that constitute the supply of potential entrepreneurs. The supply and demand forces operate in the market defined in terms of the incentive structure and the motivation of people to engage in entrepreneurial activity. Using the framework is expected to help guide the work on measurement and analysis of entrepreneurial capacity in different countries.

Following Acs et al. (2005), Henderson (2006), Evans and Leighton (1989), and Folster, (2000), this study employs self-employment as a measure of entrepreneurial activity. Although this may not be the ideal measure of entrepreneurial activity, this measure as specifically represented by the number of nonfarm proprietors is available for county-level analysis in various years. Furthermore, the self-employment rate has been used as a standard measure of entrepreneurship in the literature. In addition, measures of entrepreneurship derived from 
published data in US Census Bureau's Statistics of U.S. Businesses on firm births are used to construct entrepreneurship variables included in the analyses. 


\section{CHAPTER 3}

\section{THEORETICAL FRAMEWORK}

Schumpeter (1934) was the first to study the role of business dynamics in economic development. He referred to business dynamics as the entry and exit of firms which are connected, in his theory, to innovation and growth through "creative destruction." He describes the process of how entrepreneurship challenges incumbent firms by introducing new products that make the current ones obsolete. Businesses gain profits through innovation which stimulates imitation and entry of new firms. Hence, the level of profits drop and businesses are encouraged to innovate again. Therefore, the entry of firms is viewed positively as they bring new ideas and products in the market. Also, firm entrants intensify competition which leads to the stimulation

of existing firms to perform better. Exiting firms may also contribute to economic growth by creating opportunities for new entrants, although this is considered as an indirect effect. Schumpeter's theory is summarized by the contribution of business dynamics to economic growth through selection and innovation (van Stel, 2006).

\subsection{THE KNOWLEDGE SPILLOVER THEORY OF ENTREPRENEURSHIP}

Acs and Armington (2005) extended the endogenous growth theory as it fails to incorporate the transmission of knowledge through entrepreneurship in achieving economic growth. The knowledge-based growth model states that new knowledge in the form of products and organizations leads to market opportunities. However, this process requires a link towards commercialization of knowledge where the link is referred to as entrepreneurship (Audretsch and Keilbach, 2005). To remedy the shortcomings of the endogenous growth theory in converting 
knowledge to growth through entrepreneurship, Acs and Armington (2005) have proposed additional assumptions. These assumptions state that the creation of firms is the primary mechanism to commercialize knowledge leading to economic growth. A high level of firm creation is necessary to sustain growth, and the success of converting knowledge into an economically useful state depends on the characteristics of local entrepreneurs and the conditions of the local entrepreneurial environment. In sum, the theory suggests that increases in knowledge leads to higher growth only if the knowledge is economically useful and if there is an entrepreneurial climate that can support the transformation of knowledge into commercial use.

The Knowledge Spillover Theory of Entrepreneurship transformed the traditional approach to entrepreneurship by holding the characteristics of individuals constant and treating entrepreneurship as an endogenous response to the incomplete commercialization of knowledge, giving rise to the missing link in recent economic growth models (Audretsch, Keilbach, and Lehmann, 2006). The theory challenges two assumptions driving the results of the endogenous growth models. First is the assumption that knowledge is automatically equated with economic knowledge. Second is that knowledge is directly equated with automatic spillover, yielding to endogenous growth. Arrow (1962) pointed out that knowledge is different from the traditional factors of production, which results in a difference between knowledge and what he referred to as economic or commercialized knowledge. Also, in the Knowledge Spillover Theory of Entrepreneurship, the knowledge filter imposes a gap between new knowledge and new economic knowledge which means a lower level of knowledge spillovers.

As a result of the knowledge filter, entrepreneurship becomes an important source of economic growth by serving as a channel for knowledge spillovers. The entrepreneur becomes 
the agent of change, who recognizes the opportunities pursuing new ideas into commercialization through the process of starting a firm.

The endogenous growth model (Romer, 1986; Lucas, 1988) starts with the production function expressed as

$$
Y=K^{\alpha}\left(A L_{y}\right)^{(1-\alpha)}
$$

where $\mathrm{Y}$ is economic output, $\mathrm{K}$ is capital, $\mathrm{L}_{\mathrm{y}}$ is the labor force in producing $\mathrm{Y}$, and $\mathrm{A}$ is the stock of knowledge capital. The capital accumulation from Solow (1956) is

$$
K=s Y-\Delta K
$$

where $\mathrm{s}$ is the saving rate and $\Delta$ is the depreciation rate of capital. The R\&D sector is modeled as

$$
A=\bar{\delta} L_{A}
$$

Where $\bar{\delta}$ is the discovery rate of new innovations with

$$
\bar{\delta}=\delta L_{A}^{1-\lambda} A^{\phi}
$$

$\mathrm{L}_{\mathrm{A}}$ is the amount of labor active in the generation of new knowledge, $\lambda$ represents the returns to scale in $R \& D$, and $\phi$ is a parameter that expresses the intensity of knowledge spillovers. Inserting equation 4 into equation 3, we derive the rate of creation of new knowledge (the rate of endogenous technical change) giving:

$$
A=\delta L_{A}^{\lambda} A^{\phi}
$$

In the Romer and Lucas models, knowledge spills over and is commercialized, reflecting the Arrow observation of new knowledge. Hence, investments in R\&D and human capital automatically affect output in a multiplicative manner, suggesting that knowledge, A, is commercialized economic knowledge $A_{c}, A=A_{c}$. 
As emphasized by Arrow, there is a gap existing between investments in knowledge and the commercialization of knowledge, $\mathrm{A}-\mathrm{A}_{\mathrm{c}}>0$. The gap is defined as the knowledge filter, denoted as $\theta$, hence

$$
\theta=A_{c} / A, \text { with } 0 \leq A_{c} \leq A \text { hence } \theta \in[0,1]
$$

where $\theta$ denotes the permeability of the knowledge filter. The existence of the knowledge filter, or the knowledge not commercialized by incumbent enterprises, generates the entrepreneurial opportunities. As long as the incumbent businesses cannot exhaust the commercialization of opportunities from their investments in new knowledge, opportunities are generated for potential entrepreneurs to commercialize knowledge by starting a new firm. Thus, the actual level of new technological knowledge used by incumbent firms is

$$
A=\theta \times \delta L_{A}^{\lambda} A^{\phi}
$$

The remaining part $(1-\theta)$ is opportunities opp that can be taken by new firms, denoted as entrepreneurial opportunities, thus,

$$
A_{\text {opp }}=(1-\theta) A=(1-\theta) \times \delta L_{A}^{\lambda} A^{\phi}
$$

Based on these arguments, the economic performance hypothesis is derived. Entrepreneurial activity will increase the level of economic output since entrepreneurship serves as a mechanism facilitating the spillover and commercialization of knowledge. The production function is expressed as:

$$
Y=K^{\alpha}\left(\theta_{r} A\right)^{(1-\alpha)} L_{y}^{(1-\alpha)}
$$

where $\theta_{r}$ is the realized permeability of the knowledge filter, that is, the level that includes the

part of $(1-\theta)$ that has been taken on by startup firms. Thus, $\theta_{r} \in[0,1-\theta]$ or $\theta \leq \theta_{r} \leq 1$. An 
increase in the entrepreneurial activity increases $\theta_{r}$ and hence the distance between $\theta$ and $\theta_{r}$. The first derivative of the production function gives

$$
\frac{d Y}{d \theta_{r}}=(1-\alpha) \theta_{r}^{-\alpha} K^{\alpha} A^{(1-\alpha)}=\frac{1-\alpha}{\theta_{r}} Y,
$$

which is greater than zero for all $\mathrm{Y}$, thus, the economic output, increases with entrepreneurial activity.

\subsection{STAGES OF ECONOMIC DEVELOPMENT AND GLOBALIZATION}

Development economists have distinguished three stages of economic development. Porter (1990) defined these stages as (1) factor-driven stage, (2) efficiency-driven stage, and (3) innovation-driven stage. In the first stage, the economy specializes in the production of agricultural products and in small-scale manufacturing, marked with high rates of nonagricultural self-employment. Countries in the first stage compete through low cost efficiencies in the production of commodities of low value-added products. In the second stage, the economy shifts from small scale production to manufacturing. To compete in the second stage, countries must have efficient productive practices with large markets, which allow companies to exploit economies of scale. The efficiency-driven stage is marked by decreasing rates of selfemployment. Economists such as Kuzents (1966) and Schultz (1988) explained several reasons for the decline in entrepreneurial activity as economies become more developed. If individuals have different levels of managerial ability, then as the economy becomes wealthier, the average firm size should increase as better managers run the companies. Average firm size is an increasing function of the wealth in the economy if capital and labor are substitutes. When capital and labor are substitutes, an increase in capital stock increases the returns from working 
and decreases the returns from managing. Thus, marginal managers find that they can earn more money while being employed by somebody else. In this model of economic development, increases in capital stock increases the returns to wage work relative to entrepreneurial activity. In this case, the relationship between entrepreneurial activity and economic development would be negative. Therefore, as the economy becomes more developed, fewer people are pursuing entrepreneurial activity.

The third stage is the innovation-driven stage, marked by an increase in entrepreneurial activity. Recent studies have confirmed that it happened in most developed countries in the 1970s and 1980s (Acs et al, 1994). The empirical evidence shows that firm size distribution in developed countries began to shift away from larger corporations and towards entrepreneurial activity. Acs (2006) explained the reasons why this occurs in the final stage of economic activity. First, the innovation-driven stage is marked by decreases in the share of manufacturing in the economy. All industrialized market economies experienced a decline in manufacturing over the last 30 years. The business service sector expanded relative to manufacturing. Service firms are smaller on average than manufacturing firms, thus, economy-wide average firm size declines. In addition, service firms provide more opportunities for entrepreneurial activity. Second, technological change during the post war period has been biased towards industries in which entrepreneurial activity is important (Jorgenson, 2001). Improvements in information technologies, such as telecommunications, may increase returns to entrepreneurship. Express mail services, personal computers, photocopying services, the Internet, web site services, and mobile phones all make it less expensive and less time consuming for geographically separate individuals to exchange information. Third, Aquilina et al. (2006) concluded that a high value of the elasticity of factor substitution not only leads to more per capita capital, but makes it at the 
same time easier for an individual to become an entrepreneur if the aggregate elasticity of substitution is also negative. In an economy characterized by higher values of the aggregate elasticity of substitution, a higher level of development is expected with more entrepreneurs and smaller firms.

Therefore, it is expected that economies in the early and middle stages of economic development, entrepreneurial activity would be negatively related to economic development since most people would be trying to move from self-employment to wage employment. In developed economies, entrepreneurial activity would be positively related to economic development as people shift from wage-earning jobs to entrepreneurial activity. This framework implies the U-shaped relationship between entrepreneurship and economic development in the global economy.

\subsection{ENTREPRENEURSHIP AND NEW GROWTH THEORY}

The Schumpeterian perspective on exploiting knowledge spillovers accruing from aggregate knowledge investment is not adequately explained in the new growth theory. The models assume that knowledge automatically transforms into commercial activities, or what Arrow (1962) classifies as economic knowledge. However, this assumption lacks intuition as well as empirical backing. It is one thing for technological opportunities to exist, but it is a different matter for them to be discovered, exploited, and commercialized. Acs and Varga (2002) suggest that if it is to understand endogenous economic growth, there is a need to answer the questions of how technological advance occurs, and what are the key processes and institutions involved. 
This gap can be filled by the notion of entrepreneurial opportunity. An entrepreneurial opportunity includes a set of ideas, beliefs, and actions that enables the creation of future goods and services in the absence of current markets for them. Entrepreneurship "seeks to understand how to transform opportunities into existence, into the future where goods and services are created, discovered and exploited, by whom and with what consequences" (Shane and Venkataraman, 2000).

According to Acs and Armington (2006), there are four sources of opportunities. First is the disequilibrium within existing markets due either to information asymmetries among market participants or to the limitations of technology to satisfy certain known but unfulfilled market needs. They argue that the exploitation of these opportunities will not lead to sustained technological change. The second is the emergence of significant changes in social, political, demographic, and economic forces that can be exploited for economic gain and are largely outside the control of individual agents. However, these cannot explain continuous growth. The third source of opportunity is the accumulated stock of knowledge that exists in every society. However, the opportunities to exploit existing knowledge will diminish over time. New knowledge is the fourth source. Many opportunities that have a systematic impact on future economic growth come from the R\&D expenditures in the economy (Schmookler, 1966). Technological change is an important source of entrepreneurial opportunity because it makes it possible for people to allocate resources in different and potentially more productive ways (Casson, 1995).

One way in which people discover technological opportunity is through knowledge spillovers from others. Entrepreneurial discovery is in fact a process of knowledge spillover where knowledge in a non-rival good. Once the entrepreneurs discover new opportunities, they 
have the chance to exploit them. While formal $R \& D$ creates opportunities in large firms and universities, it is frequently different individuals in different entities that carry out the exploitation of opportunities. New knowledge by itself may only be a necessary condition for the exercise of successful enterprise in a growth model. The ability to make the connection between new knowledge and commercial opportunity requires a set of skills, aptitudes, and circumstances that is neither uniformly nor widely distributed in the population. Thus, two people with the same new knowledge may put it to very different uses. It is one thing to have an insight, but a different thing to profit from it. The incentive, capability, and specific behaviors needed for profit from useful knowledge or insight all vary among individuals, and these differences matter for explaining the entry to entrepreneurial activity.

If an agent has an idea for something different than is currently being practiced by an incumbent enterprise in terms of a new product or process idea, which is termed as an innovation, it will be presented to the incumbent enterprise. Assuming perfect information, both the firm and the agent will agree on the expected value of the innovation. However, to the degree that any economies of scale exist, the expected value of implementing the innovation within the incumbent enterprise will exceed that of taking the innovation outside of the incumbent firm to start a new enterprise. Thus, the incumbent enterprise and the inventor of the idea would be expected to reach a bargain, splitting the value-added to the firm contributed by the innovation (Audretsch, 1995).

Knight (1921) and others emphasized new economic knowledge is anything but certain. Not only is new economic knowledge inherently risky, but also substantial asymmetry exists between agents and firms. The expected value of a new idea or innovation is likely to be estimated quite differently by the inventor of the idea and by the decision makers of the firm 
confronted with proposed innovations. It is because of the uncertainties of information that Knight (1921) argues that the primary task of the firm is to process imperfect information in order to reach a decision.

\subsection{ENTREPRENEURSHIP AS A FILTER IN ENDOGENOUS GROWTH}

In order to remedy the limitations of the endogenous growth model and to specify the nature of the transmission mechanism that generates a diffusion of knowledge, Acs and Armington (2006) propose changing the assumptions on the distribution of knowledge (knowledge spillovers) and the role of new firms (entrepreneurship). The assumptions are (1) new firms are assumed to be the primary mechanism to transmit knowledge, $\mathrm{K}$. $\mathrm{K}$ is transformed into economically relevant knowledge $\left(\mathrm{K}^{\mathrm{C}}\right)$ via spillovers, which are exploited in new ventures regardless of whether the knowledge is new or existing, and whether it is scientific or some other kind of knowledge. Existing firms may learn and thereby add to their firm-specific knowledge, but the results of such learning takes the form of new ventures. This means that if there are no start-ups, there is no spillover and hence no growth; (2) each new firm represents an innovation, any new combination of new or existing knowledge, as suggested by Schumpeter (1934). The implication is that firms are heterogeneous, not only in the size dimension but also in terms of all characteristics, such as absorptive capacity, strategy, technology, and product range, and all aspects of performance; (3) there are no interregional spillovers, only local. Access to stock of knowledge is assumed to be equal to all local entities, but the success in converting general knowledge depends on the absorptive capacity of each firm and hence firm characteristics; (4) the conditions for knowledge transmission and hence new firm formation vary across regions. Policy and previous history determine the entrepreneurial climate in the form of infrastructure, 
regulations, attitudes, networks, technology transfer mechanisms, etc; and (5) entrepreneurial ability is distributed unevenly across individuals. They deploy their endowments of entrepreneurial capabilities to evaluate the knowledge accessible to them in reaching a decision how best to appropriate the returns from that knowledge.

The combined results of these assumptions, when considered in the endogenous growth model, can be characterized as a filter that determines the rate at which the stock of knowledge $(\mathrm{K})$ is converted into economically useful firm-specific knowledge $\left(\mathrm{K}^{\mathrm{C}}\right)$ :

$$
0 \leq K^{C} / H \leq 1
$$

Two conditions, thus, are decisive for an increasing stock of knowledge to materialize in higher economic growth; first, knowledge has to be economically useful and second, an economy must be endowed with factors of production that can select, evaluate, and transform knowledge into commercial use, that is, entrepreneurs. If these conditions are not fulfilled, an increase in the knowledge stock may have no impact on growth. Similarly, regions with smaller knowledge stocks may experience higher growth than regions that are more abundantly endowed with knowledge due to superior links to the market.

The basic structure of the model implies that we have two types of firms. First, we have incumbent firms (I), which have a history and have accumulated knowledge over time,

$$
k_{i, j, t}^{I}=f\left(\int_{t=0}^{\infty} k_{i, j, t}^{I}, K\right), \sum_{i, j}^{n} k^{I}=K^{I}
$$

At each given point in time, firm-specific knowledge of the incumbent firms $i$ in industry $j$ depends on their previous investment in knowledge and on the size of $K$ at time $t$. The already accumulated firm-specific knowledge within the incumbent firms has two implications for their ability to exploit new knowledge spillovers from $K$. First, the size of accumulated firm-specific 
knowledge determines their capacity to draw on spillovers (their absorptive capacity), and second the degree of the firm specificity constrains the absorption of knowledge spillovers. Hence, the incumbent firm's ability to exploit spillovers is determined by path dependence and the specificity of the accumulated knowledge.

The second type of firm is start-ups, that is, newly formed firms. These differ from incumbents, since the knowledge is not governed by path dependence and history to the same extent. Rather, it builds on an entrepreneur's ability to exploit an opportunity arising from aggregate spillovers,

$$
k_{i, t}^{s}=f(K), \sum_{i}^{n} k^{s}=K^{s}
$$

Start-ups entering the market thus produce genuinely new products or use new processes. $\mathrm{K}^{\mathrm{S}}$ in period 1 becomes encapsulated in $\mathrm{K}^{\mathrm{I}}$ in the subsequent periods. At the aggregate level, the relationship between $\mathrm{K}^{\mathrm{S}}$ in the previous period and $\mathrm{K}^{\mathrm{I}}$ in the current period reflects the presence of entrepreneurship in an economy.

Both types of firms thus contribute to the exploitation of knowledge spillovers. Thereby they will narrow the gap between total spillovers $(\mathrm{K})$ and the share of those knowledge spillovers that are commercialized. Yet, a complete mapping between $\mathrm{K}^{\mathrm{C}}$ and $\mathrm{K}$ is unrealistic. Rather, Acs and Armington (2006) postulate that

$$
K^{C}=K^{C I}+K^{C S}
$$

where

$$
K^{C I}=\theta K, K^{C S}=\lambda K ; 0 \leq(\lambda+\theta) \leq 0 .
$$

hence,

$$
K \geq K^{C}=K^{C I}+K^{C S}
$$


and

$$
K^{C}=(\theta+\lambda) K
$$

assuming for the moment that spillovers are independent of the spatial dimension. The absorptive capacity of incumbent firms is $\theta$ and $\lambda$ is the proxy for entrepreneurship within an economy. In accordance, with assumptions 1 and 2, the production function then also accounts for entrepreneurship. Thus if entrepreneurship is nonexistent in an economy, knowledge spillovers will not provide the same solution as in the endogenous growth model with automatic spillovers. In fact, it will then reduce to the neoclassical growth model. In addition, it is obvious that it is not only the size of $\mathrm{K}$ and the absorptive capacity of incumbent firms that matter but also the presence of entrepreneurs. 


\section{CHAPTER 4}

\section{EMPIRICAL MODEL AND DATA DESCRIPTION}

\subsection{GROWTH MODEL}

The main objective of this study is to examine the role of entrepreneurship in economic development represented by changes in employment, income, and population. In addition to entrepreneurship, the empirical tests include several socio-economic variables affecting economic growth. Based on previous studies, this study adopts the use of regional economic growth models in examining the relationship between entrepreneurship and economic growth. The simultaneous equation model in this study is based on the classic two-equation model of Carlino and Mills (1987). Their model employs population and employment dynamics in determining how regional factors affect patterns of growth. The emphasis is that households and firms aim to maximize utility by consuming goods and services, residential location relative to the place of work, and non-market amenities. The Carlino-Mills model recognizes that population growth interacts with employment growth in the same field. That is, without constraints on capital mobility and other barriers among regions, equilibrium of population and employment growth is reached when factors of production in all regions get the same economic return. The model has been widely used in estimating how different regional factors affect longrun economic growth.

Deller et al. (2001) expanded the model into a three-equation framework by incorporating the role of income in regional economic growth. This is based on the assumption that households and firms also consider labor quality to maximize utility. In sum, the model represents that firms choose an optimal location based on location cost and revenue advantages, agglomeration benefits, and labor quality. 
Following Deller et al. (2001), Nzaku and Bukenya (2005) and Deller (2007), this study employs the model representing the relationship among population (P), employment (E), and income (I). The general form of the three-equation model is:

$$
\begin{aligned}
& P^{*}=f\left(E^{*}, I^{*} / \Omega^{P}\right) \\
& E^{*}=g\left(P^{*}, I^{*} / \Omega^{E}\right) \\
& I^{*}=h\left(P^{*}, E^{*} / \Omega^{I}\right)
\end{aligned}
$$

where $P^{*} * E^{*}$, and $I^{*}$ represent the equilibrium levels of population, employment, and per capita income, respectively, and $\Omega^{P}, \Omega^{E}$, and $\Omega^{I}$ are a set of variables describing initial conditions, measures of entrepreneurship, and other variables that are traditionally linked to economic growth. From the equilibrium framework of the model, a simple linear relationship among the variables can be presented as:

$$
\begin{aligned}
& P^{*}=\alpha_{0 P}+\beta_{1 P} E^{*}+\beta_{2 P} I^{*}+\sum \delta_{I P} \Omega^{P} \\
& E^{*}=\alpha_{0 E}+\beta_{1 E} P^{*}+\beta_{2 E} I^{*}+\sum \delta_{I E} \Omega^{E} \\
& I^{*}=\alpha_{0 I}+\beta_{1 I} P^{*}+\beta_{2 I} E^{*}+\sum \delta_{I I} \Omega^{I}
\end{aligned}
$$

Furthermore, population, employment, and income are likely to adjust to their equilibrium levels with initial conditions (Mills and Price, 1984). These distributed lag adjustments are incorporated to the model expressed as:

$$
\begin{aligned}
& P_{t}=P_{t-1}+\lambda_{P}\left(P^{*}-P_{t-1}\right) \\
& E_{t}=E_{t-1}+\lambda_{E}\left(E^{*}-E_{t-1}\right) \\
& I_{t}=I_{t-1}+\lambda_{I}\left(I^{*}-I_{t-1}\right)
\end{aligned}
$$

where $\mathrm{P}_{\mathrm{t}-1}, \mathrm{E}_{\mathrm{t}-1}$, and $\mathrm{I}_{\mathrm{t}-1}$ are initial conditions of population, employment and per capita income, respectively; $\lambda_{\mathrm{P},} \lambda_{\mathrm{E}}$, and $\lambda_{\mathrm{I}}$ are speed adjustment coefficients to the desired level of population, 
employment, and income, which are generally positive, with larger values indicating faster growth rates. Current employment, population and income levels are functions of their initial conditions and the change between the equilibrium values and initial conditions at their respective values of speed of adjustment $(\lambda)$. Substituting equations 24, 25, and 26 into equations 21,22 and 23 while slightly rearranging the terms gives the model to be estimated and expressed as:

$$
\begin{aligned}
& \Delta P=\alpha_{0 P}+\beta_{1 P} P_{t-1}+\beta_{2 P} E_{t-1}+\beta_{3 P} I_{t-1}+\gamma_{1 P} \Delta E+\gamma_{2 P} \Delta I+\sum \delta_{I P} \Omega^{P} \\
& \Delta E=\alpha_{0 E}+\beta_{1 E} P_{t-1}+\beta_{2 E} E_{t-1}+\beta_{3 E} I_{t-1}+\gamma_{1 E} \Delta P+\gamma_{2 E} \Delta I+\sum \delta_{I E} \Omega^{E} \\
& \Delta I=\alpha_{0 P}+\beta_{1 I} P_{t-1}+\beta_{2 I} E_{t-1}+\beta_{3 I} I_{t-1}+\gamma_{1 I} \Delta E+\gamma_{2 I} \Delta P+\sum \delta_{I I} \Omega^{I}
\end{aligned}
$$

where $\Delta \mathrm{P}, \Delta \mathrm{E}$, and $\Delta \mathrm{I}$ are the region's changes in population, employment and per capita income, respectively. The speed of adjustment becomes embedded in the coefficient parameters $\alpha, \beta$, and $\delta$. Following Deller (2007), this model captures structural relationships while simultaneously isolating the influence of the level of entrepreneurship on regional economic growth. The equations estimate short-term adjustments of population, employment and income $(\Delta P, \Delta E$, and $\Delta I)$ to their long-term equilibrium $\left(P^{*}, E^{*}\right.$, and $\left.I^{*}\right)$.

For the purpose of this study, measures of entrepreneurship are incorporated in the model, in addition to the variables that are traditionally linked to economic growth. These variables include measures of human capital, infrastructure, agglomeration, and a vector of additional socio-economic variables. The model estimation also investigates whether the degree of urbanization impacts economic growth. This is done by using a dummy variable to identify metro and non-metro counties. This specifically determines the effect of agglomeration to economic growth as rural areas are found to be more likely to engage in entrepreneurship than 
the metro areas, although urban areas are more successful in turning a business start into a highgrowth business (Drabenstott, 2004).

\subsection{ENDOGENEITY TEST}

Most studies found a positive effect of entrepreneurship on economic growth revealing that entrepreneurship increases employment and income levels. However, some studies showed that economic growth is also found to influence entrepreneurship (Storey, 2003). Entrepreneurship is likely to be endogenous in the model since counties with high levels of economic growth have a strong incentive for individuals to start businesses. On the other hand, counties with low levels of economic growth are found to be more likely to spawn small businesses. Hence, a test for possible endogeneity is done as model estimation is biased when entrepreneurship variables are endogenous. Hausman's test under the null hypothesis of no endogeneity is employed to test whether entrepreneurship is endogenous. If the entrepreneurship index is exogenous, the model presented above will be estimated in reduced form. That is, the simultaneous equations can be solved equation by equation, given that the conditions for identification are satisfied. Estimation procedures are heavily drawn from the methods of Greene (1997) and Wooldridge (2002). The Statistical Packages for the Social Sciences (SPSS) is used for the empirical tests.

If the entrepreneurship measure is found to be endogenous and there exists a simultaneous relationship between the growth measures and the entrepreneurship index, the model will be expanded into a four-equation model expressed as: 


$$
\begin{aligned}
& P^{*}=f\left(E^{*}, I^{*}, E n^{*} / \Omega^{P}\right) \\
& E^{*}=g\left(P^{*}, I^{*}, E n^{*} / \Omega^{E}\right) \\
& I^{*}=h\left(P^{*}, E^{*}, E n^{*} / \Omega^{I}\right) \\
& E n^{*}=f\left(E^{*}, I^{*}, P / \Omega^{E n}\right)
\end{aligned}
$$

where $P^{*}, E^{*}, I^{*}$, and $E n^{*}$ represent the equilibrium levels of population, employment, per capita income, and entrepreneurship respectively, and $\Omega^{P}, \Omega^{E}, \Omega^{I}$, and $\Omega^{E n}$, are a set of variables describing initial conditions, and other variables that are traditionally linked to economic growth. Following the transformation of equations above, the model to be estimated is:

$$
\begin{aligned}
& \Delta P=\alpha_{0 P}+\beta_{1 P} P_{t-1}+\beta_{2 P} E_{t-1}+\beta_{3 P} I_{t-1}+\beta_{4 P} E n_{t-1}+\gamma_{1 P} \Delta E+\gamma_{2 P} \Delta I+\gamma_{3 P} \Delta E n+\sum \delta_{I P} \Omega^{P} \\
& \Delta E=\alpha_{0 E}+\beta_{1 E} P_{t-1}+\beta_{2 E} E_{t-1}+\beta_{3 E} I_{t-1}+\beta_{4 E} E n_{t-1}+\gamma_{1 E} \Delta P+\gamma_{2 E} \Delta I+\gamma_{3 E} \Delta E n+\sum \delta_{I E} \Omega^{E} \\
& \Delta I=\alpha_{0 I}+\beta_{1 I} P_{t-1}+\beta_{2 I} E_{t-1}+\beta_{3 I} I_{t-1}+\beta_{4 I} E n_{t-1}+\gamma_{1 I} \Delta E+\gamma_{2 I} \Delta P+\gamma_{3 I} \Delta E n+\sum \delta_{I I} \Omega^{I} \\
& \Delta E n=\alpha_{0 E n}+\beta_{1 E n} P_{t-1}+\beta_{2 E n} E_{t-1}+\beta_{3 E n} I_{t-1}+\beta_{4 E n} E n_{t-1}+\gamma_{1 E n} \Delta P+\gamma_{2 E n} \Delta E+\gamma_{3 E n} \Delta I+\sum \delta_{I E n} \Omega^{E n} \text { (37) }
\end{aligned}
$$

where $\Delta \mathrm{P}, \Delta \mathrm{E}, \Delta \mathrm{I}$, and $\Delta \mathrm{En}$ are the region's changes in population, employment, per capita income, and entrepreneurship, respectively.

\subsection{SPECIFICATION OF VARIABLES}

The specified model of growth is used to analyze the impact of entrepreneurship to regional economic growth using changes in population, employment and per capita income growth as endogenous variables. Following the existing literature on entrepreneurship and economic growth (Acs and Armington, 2005; Camp, 2005; van Stel and Suddle, 2005; and 
Henderson, 2006), the model employs growth measures as endogenous variables. The model is specified as an equation with dependent variables as functions of entrepreneurship, human capital, infrastructure, agglomeration, and a set of socio-economic variables.

The choice of variables to represent entrepreneurship is based on theoretical considerations presented in Chapter 3 and on previous studies on entrepreneurship and economic growth. The entrepreneurship variables derived from data on self employment include number of proprietors in a county (PROP), number of proprietors in a county per 1000 people in the labor force $\left(\mathrm{PROP}_{\mathrm{LF}}\right)$, number of proprietors in a county per 1000 people in the labor force between 1995 and 2005 (CHPROP $\mathrm{LF}$ ) and the growth in the number of proprietors per county (CHPROP). Measures of entrepreneurship derived from firm births per county (BIRTH), firm births per 1000 people in the labor force per county $\left(\mathrm{BIRTH} \mathrm{LF}_{\mathrm{LF}}\right)$, change in the number of firm births in a county per 1000 people in the labor force $\left(\mathrm{CHBIRTH} \mathrm{LF}_{\mathrm{LF}}\right)$, change in the number of firm expansion per county (CHEXPAND), change in the number of firm deaths per county (CHDEATH) and number of firm deaths per county per 1000 labor force $\left(\right.$ DEATH $\left._{\mathrm{LF}}\right)$. A positive relationship between the measures of entrepreneurial activity and economic growth is hypothesized based on theory and the results of previous studies. On the other hand, a negative relationship between measures of firm deaths and growth measures is hypothesized.

In addition to entrepreneurship, additional explanatory variables are included in the employment growth model to better understand the factors affecting economic growth in the Appalachian region. Human capital variables which reflect the quality of labor force is measured using share of the population with high-school education $\left(\mathrm{EDUC}_{\mathrm{HI}}\right)$. A higher share of the population with high school education indicates a higher quality of the labor force in the county. Furthermore, a higher quality of the labor force is expected to be more efficient and 
therefore reduces the average cost of the business leading to a higher employment and income growth. Hence, a positive relationship between the human capital variable and the measures of economic growth is hypothesized.

Infrastructure variables include the county's miles of road per square mile (ROADDEN) and miles of state road per square mile (STROADDEN). The quality of infrastructure affects the firm's average cost and is expected to affect employment and income growth. A positive relationship between the growth measures and the quality levels of a county's infrastructure is expected as infrastructure defines the ease of distribution of goods and services between the firms and the market.

Agglomeration of firms is found to positively affect growth by reduced costs of information transfer and knowledge spillovers arising from diversity (Henderson, 2006). To measure agglomeration, the empirical models include population density $\left(\mathrm{POP}_{\mathrm{DEN}}\right)$ and a dummy variable to identify metropolitan counties (METRO). Agglomeration factors are expected to have a positive effect to both employment and income growth when agglomerations increase network externalities (Ciccone and Hall, 1996).

Other socio-economic variables such as per capita income taxes (PCTAX), property taxes (PROPTAX), government expenditure per capita (GOVEX), and percent of families below poverty (POVERTY) will also be included in the empirical analyses. Taxes are expected to have a negative relationship with the measures of economic growth as it reduces demand for consuming goods and services as well as reducing firm profits. Government expenditure is hypothesized to have a positive relationship with employment and income growth as it reflects investments for the welfare of the public. On the other hand, a negative relationship between percent of families below poverty and the measures of economic growth is expected. A higher 
percentage of families in poverty indicates slower increases in employment and income levels. CRIME is hypothesized to have a negative effect on measures of economic growth while percent of population 35 to 64 years old is expected to have a positive effect. Summary of the variables used in the analyses are presented in Tables 4.1, 4.2, and 4.3.

\subsection{TYPES AND SOURCES OF DATA}

Data on 410 counties of the Appalachian region drawn from several sources are used in the empirical analysis. Endogenous variables include county level growth in population, employment and per capita income (wage levels) for years 1995 to 2005 as indicators of economic growth. These data as well as their initial values are drawn from the publications of the Regional Economic Information System - Bureau of Economic Analysis (BEA) for various years. Table 4.1 presents the summary of the definition and sources of the endogenous variables and their initial values. Figures 4.4.1, 4.4.2, and 4.4.3 are maps of Appalachia showing growths in population, employment, and per capita income between 1995 and 2005. The maps indicate the variation of data in the region used as endogenous variables which facilitates empirical analyses.

Exogenous variables include entrepreneurship measures as well as socio-economic variables such as changing demographics of the workforce and other economic variables affecting economic growth. Controlling for these factors in addition to entrepreneurship measures increases the understanding of economic development in the Appalachian region. 
Table 4.1 Definition and Sources of Endogenous Variables and their Initial Conditions

\begin{tabular}{lll}
\hline Variable & Definition & Sources \\
\hline \multicolumn{2}{l}{ Dependent variables /Growth measures } & \\
$\Delta \mathrm{P}$ & Change in population between the years 1995 and 2005 & REIS-BEA \\
$\Delta \mathrm{E}$ & Change in employment between the years 1995 and 2005 & REIS-BEA \\
$\Delta \mathrm{I}$ & Change in per capita income between the years 1995 and 2005 & REIS-BEA \\
Initial Conditions & \\
$\mathrm{P}_{\mathrm{t}-1}$ & Population in 1995 & REIS-BEA \\
$\mathrm{E}_{\mathrm{t}-1}$ & Employment in 1995 & REIS-BEA \\
$\mathrm{I}_{\mathrm{t}-1}$ & Per capita income in 1995 & REIS-BEA \\
\hline
\end{tabular}

Figure 4.4.1 Change in Population, 1995-2005

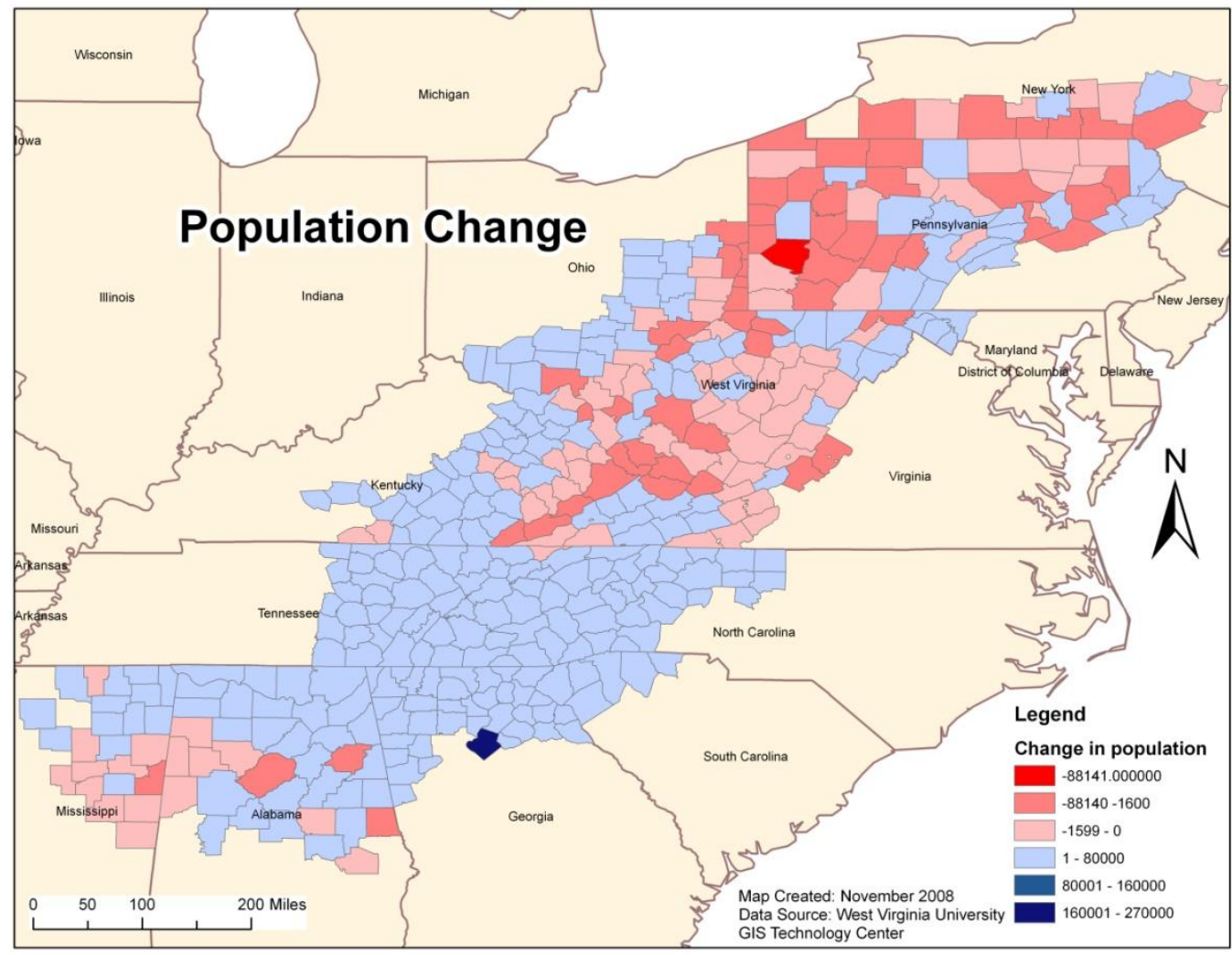

Map Created by the author 
Figure 4.4.2 Change in Employment, 1995-2005

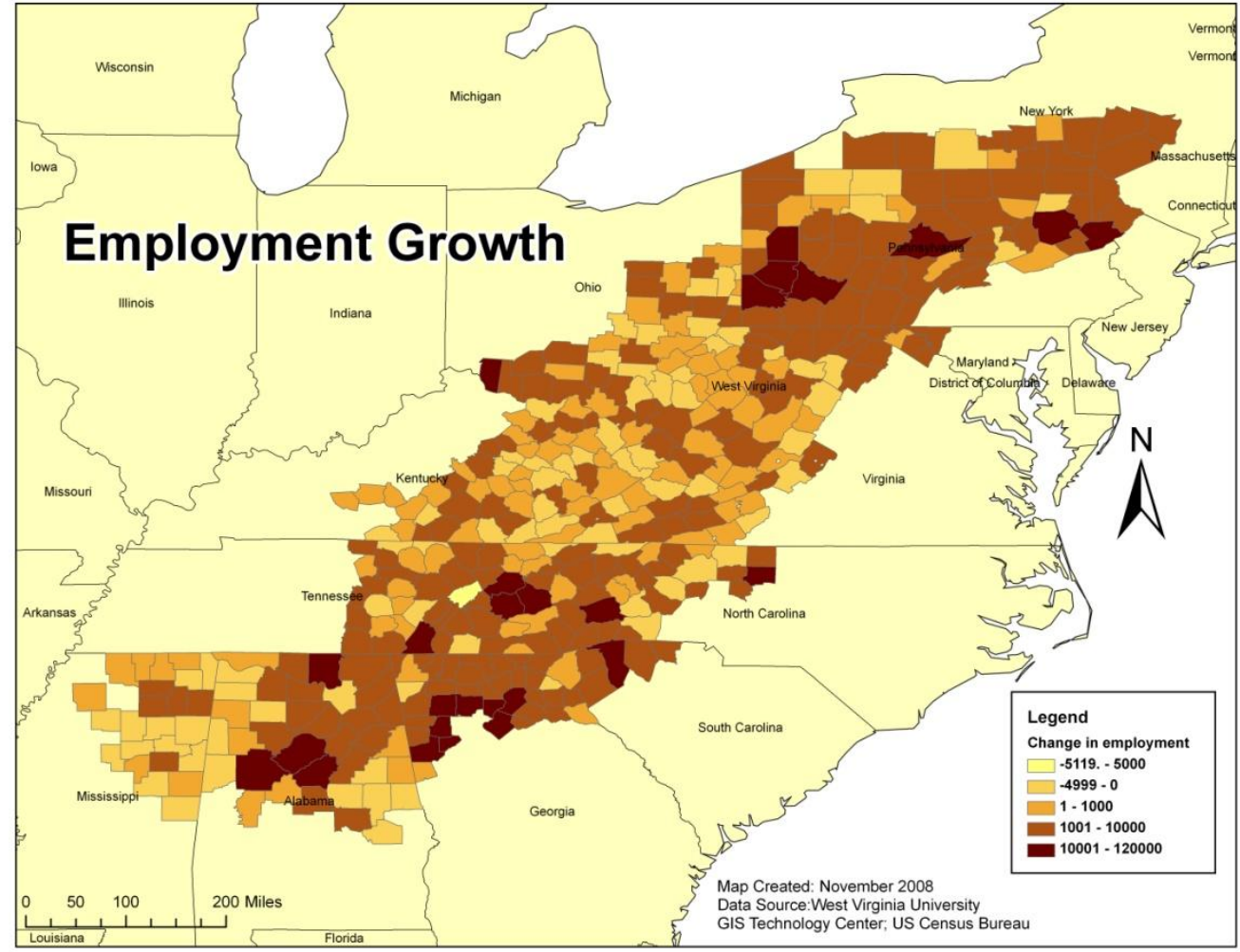

Map Created by the author

Figure 4.4.3 Change in Per Capita Income, 1995-2005

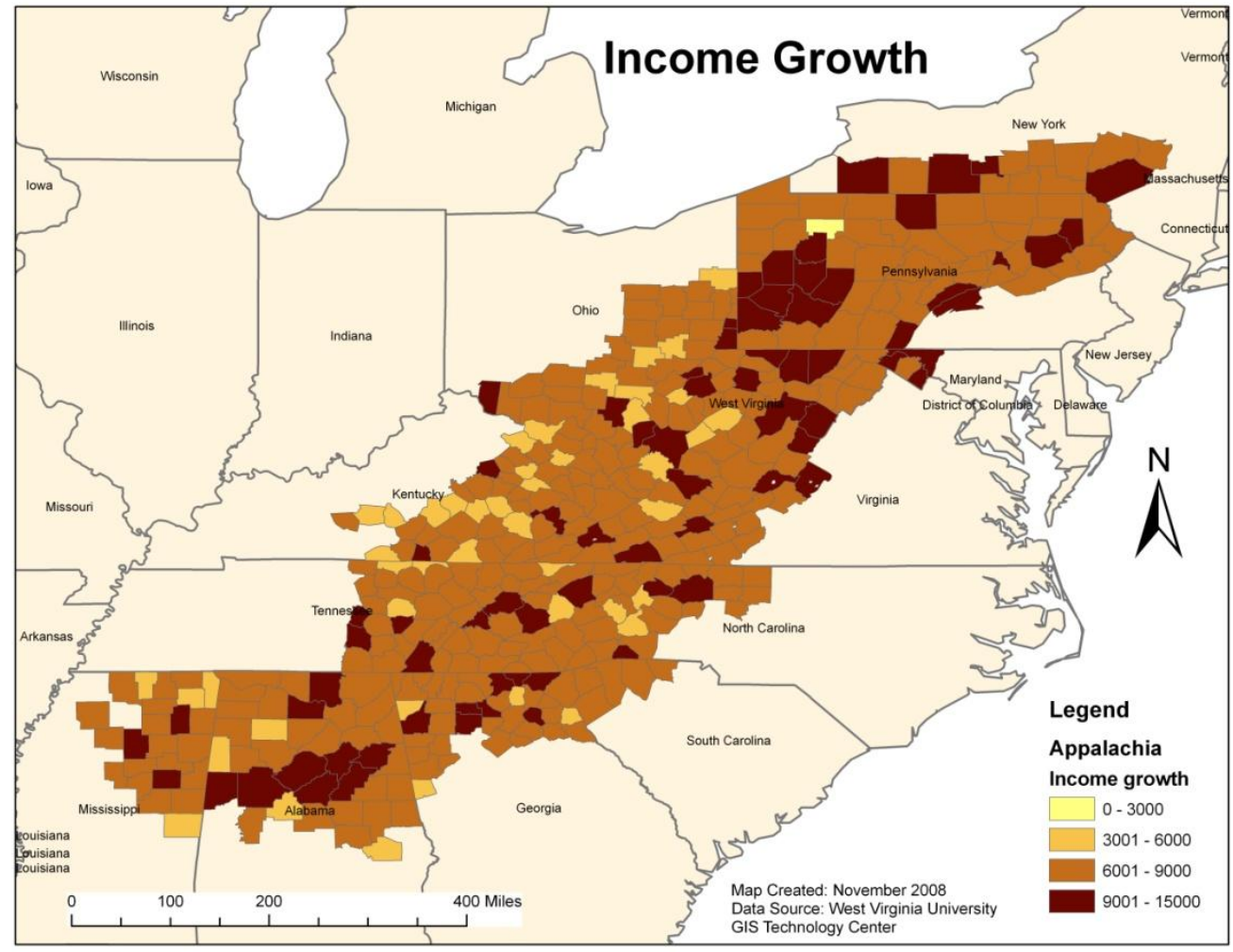


To measure entrepreneurship, the number of nonfarm proprietors in the counties drawn from the publications of the Regional Economic Information System (REIS-BEA) from the Bureau of Economic Analysis is used. REIS draws information on proprietorship from income tax files of sole proprietors and partnerships and publishes county level estimates of the number of farm and nonfarm proprietors and their incomes. The data are used to construct four variables used as indicators of entrepreneurial activity in a county. These are the number of proprietors in the county in 1995 (PROP), the number of proprietors in a county per 1000 people in the labor force $\left(\mathrm{PROP}_{\mathrm{LF}}\right)$ which is derived by dividing the number of proprietors by the total nonfarm employment multiplied by a thousand. This is based on the labor market approach of controlling for different absolute sizes of the geographical unit, in this case the counties, where the denominator is the size of the work force. The Labor Market approach assumes that entrepreneurial firms arise from the work force (Baptista, Escaria, and Madruga, 2005). The third and the fourth measures of entrepreneurial capacity are change in the number of proprietors in a county per 1000 people in the labor force between 1995 and 2005 (CHPROP $\left.{ }_{L F}\right)$ and the growth in the number of proprietors (CHPROP).

Additional measures of entrepreneurship are based on firm birth data including firm births per county (BIRTH), firm births per 1000 people in the labor force per county $\left(\mathrm{BIRTH}_{\mathrm{LF}}\right)$, change in the number of firm births in a county per 1000 people in the labor force $\left(\mathrm{CHBIRTH}_{\mathrm{LF}}\right)$, change in the number of firm expansion per county (CHEXPAND), change in the number of firm deaths per county (CHDEATH) and number of firm deaths per county per 1000 labor force $\left(\mathrm{DEATH}_{\mathrm{LF}}\right)$. Data on firm births are from the publications of the US Census Bureau's Statistics of US Businesses (SUSB). SUSB use data extracted from the Business Register, corresponding to a file of single and multi-establishment employer companies 
maintained by the US Census Bureau. Definition and data sources of entrepreneurship variables are summarized in Table 4.2.

Table 4.2 Definition and Data Sources of Entrepreneurship Variables

\begin{tabular}{|c|c|c|}
\hline Variable & Definition & Sources \\
\hline \multicolumn{3}{|c|}{ Entrepreneurship Variables } \\
\hline PROP & Number of proprietors per county in 1995 & REIS-BEA \\
\hline PROP $_{L F}$ & $\begin{array}{l}\text { Number of proprietors in a county per } 1000 \text { people in the } \\
\text { labor force in } 1995\end{array}$ & Constructed \\
\hline CHPROP $_{\mathrm{LF}}$ & $\begin{array}{l}\text { Change in the number of proprietors in a county per } 1000 \\
\text { people in the labor force between } 1995 \text { and } 2005\end{array}$ & Constructed \\
\hline CHPROP & $\begin{array}{l}\text { Change in the number of proprietors in a county between } \\
1995 \text { and } 2005\end{array}$ & Constructed \\
\hline BIRTH & Number of firm births per county in 1998 & $\begin{array}{l}\text { SUSB-U.S. } \\
\text { Census }\end{array}$ \\
\hline $\mathrm{BIRTH}_{\mathrm{LF}}$ & Firm births per 1000 people in the labor force in 1998 & Constructed \\
\hline $\mathrm{CHBIRTH}_{\mathrm{LF}}$ & $\begin{array}{l}\text { Change in the number of firm births in a county per } 1000 \\
\text { people in the labor force between } 1998 \text { and } 2005\end{array}$ & Constructed \\
\hline CHEXPAND & $\begin{array}{l}\text { Change in the number of firm expansion per county between } \\
1998 \text { and } 2005\end{array}$ & Constructed \\
\hline CHDEATH & $\begin{array}{l}\text { Change in the number of firm deaths per county between } \\
1998 \text { and } 2005\end{array}$ & Constructed \\
\hline DEATH $_{\mathrm{LF}}$ & $\begin{array}{l}\text { Number of firm deaths per county per } 1000 \text { labor force in } \\
1998\end{array}$ & Constructed \\
\hline
\end{tabular}

In addition to measures of entrepreneurship, the exogenous variables used in analyzing the factors affecting economic growth are included in the empirical models. These variables are categorized into human capital or the quality of the labor force, infrastructure, agglomeration, and other socio-demographic characteristics of the county as summarized in Table 4.3. Human capital or the quality of the labor force is measured using the share of the population with high- 
school education $\left(\mathrm{EDUC}_{\mathrm{HI}}\right)$. To control for the county's quality of infrastructure, data on the miles of road per square mile (ROADDEN) and miles of state road per square mile (STROADDEN) are used in the models.

To measure agglomeration, the empirical models include population density (POPDEN) and a dummy variable to identify metropolitan counties (METRO). Other socio-economic variables such as per capita income taxes (PCTAX), property taxes on businesses (PROPTAX), government expenditure per capita (GOVEX), and percent of families below poverty (POVERTY) are included in the empirical analyses. Natural amenities ranking (NATAMER) of the Economic Research Services (ERS-USDA) is used to account for endowment of natural amenities in Appalachian counties. Additional variables include crimes reported per 100,000 population (CRIME) and percent of population 35 to 64 years old (POP35_64). Data on explanatory variables are from the publications of the BEA-REIS, the Census Bureau, and the Economic Research Service (ERS) of the United States Department of Agriculture (USDA), and the Natural Resource Analysis Center-West Virginia University (NRAC-WVU).

Tables 4.4, 4.5, and 4.6 present the summary of descriptive statistics of endogenous variables and their lagged values, the entrepreneurship variables, and the variables that are traditionally linked to economic growth. The tables present the minimum, maximum, mean and standard deviation of 410 counties in Appalachia which are included in the analyses. 
Table 4.3 Definition and Data Sources of Socio-Demographic Variables

\begin{tabular}{|c|c|c|}
\hline Variable & Definition & Sources \\
\hline \multicolumn{3}{|c|}{ Entrepreneurship Variables } \\
\hline \multicolumn{3}{|l|}{ human capital } \\
\hline $\mathrm{EDUC}_{\mathrm{HI}}$ & Share of the population with high-school education & U.S. Census \\
\hline \multicolumn{3}{|l|}{ infrastructure } \\
\hline ROADDEN & Miles of road per square mile & NRAC-WVU \\
\hline STROADDE & & \\
\hline $\mathrm{N}$ & Miles of state road per square mile & NRAC-WVU \\
\hline \multicolumn{3}{|l|}{ agglomeration } \\
\hline POPDEN & Population density & REIS-BEA \\
\hline \multirow{3}{*}{$\begin{array}{l}\text { METRO } \\
\text { other } \\
\text { variables }\end{array}$} & Dummy variables to identify metropolitan counties & U.S. Census \\
\hline & & \\
\hline & & County and City \\
\hline \multirow[t]{2}{*}{ PCTAX } & Per capita income taxes & Data \\
\hline & & County and City \\
\hline \multirow[t]{2}{*}{ PROPTAX } & Property tax per capita & Data \\
\hline & & County and City \\
\hline \multirow[t]{2}{*}{ GOVEX } & Government expenditure per capita & Data \\
\hline & & County and City \\
\hline POVERTY & Percent of families below poverty & Data \\
\hline \multirow[t]{2}{*}{ NATAMER } & Natural amenities ranking & ERS-USDA \\
\hline & & County and City \\
\hline \multirow[t]{2}{*}{ CRIME } & Crimes reported per 100,000 of population & Data \\
\hline & & County and City \\
\hline POP35_64 & Share of population 35 to 64 years old & Data \\
\hline
\end{tabular}


Table 4.4 Descriptive Statistics of Endogenous Variables and Initial Conditions.

\begin{tabular}{lcccc}
\hline Variable & Minimum & Maximum & Mean & Standard Deviation \\
\hline Endogenous Variables & & & & \\
$\Delta \mathrm{P}$ & -88141 & 252636 & 3589.30 & 16359.21 \\
$\Delta \mathrm{E}$ & -5119 & 118600 & 3398.39 & 8692.32 \\
$\Delta \mathrm{I}$ & 2880 & 14738 & 7765.54 & 1720.59 \\
Initial Conditions & & & & \\
$\mathrm{P}_{\mathrm{t}-1}$ & 2566 & 1322460 & 53692.63 & 91220.84 \\
$\mathrm{E}_{\mathrm{t}-1}$ & 1203 & 825870 & 27139.84 & 56668.27 \\
$\mathrm{I}_{\mathrm{t}-1}$ & 10180 & 28369 & 16790.71 & 2832.76 \\
\hline
\end{tabular}

Table 4.5 Descriptive Statistics of Entrepreneurship Variables.

\begin{tabular}{|c|c|c|c|c|}
\hline Variable & Minimum & Maximum & Mean & $\begin{array}{l}\text { Standard } \\
\text { Deviation }\end{array}$ \\
\hline PROP & 262.00 & 96914.00 & 4001.57 & 6962.20 \\
\hline $\mathrm{PROP}_{\mathrm{LF}}$ & 76.51 & 496.06 & 173.99 & 53.47 \\
\hline $\mathrm{CHPROP}_{\mathrm{LF}}$ & -164.52 & 266.81 & 41.28 & 55.08 \\
\hline CHPROP & -2645.00 & 31539.00 & 1469.00 & 2883.39 \\
\hline BIRTH $_{L F}$ & 0.38 & 2816.00 & 11.50 & 139.04 \\
\hline $\mathrm{CHBIRTH}_{\mathrm{LF}}$ & -20.94 & 204.00 & 0.08 & 10.40 \\
\hline BIRTH & -19.00 & 2946.00 & 116.40 & 239.22 \\
\hline CHBIRTH & -357.00 & 438.00 & 2.17 & 46.16 \\
\hline CHEXPAND & -355.00 & 7884.00 & 18.78 & 392.49 \\
\hline CHDEATH & -147.00 & 2802.00 & 6.45 & 140.98 \\
\hline DEATH $_{L F}$ & 0.16 & 46.71 & 4.08 & 3.09 \\
\hline
\end{tabular}


Table 4.6 Descriptive Statistics of Education, Agglomeration, Infrastructure, Natural Amenities, Government Expenditure, Taxes, and Crime Rate.

\begin{tabular}{lrrrr}
\hline Variable & Minimum & Maximum & \multicolumn{1}{c}{ Mean } & \multicolumn{2}{c}{$\begin{array}{c}\text { Standard } \\
\text { Deviation }\end{array}$} \\
\hline EDUC ${ }_{\text {HI }}$ & & & & \\
METRO & 35.50 & 87.20 & 61.19 & 10.16 \\
POPDEN & 0.00 & 1.00 & 0.26 & 0.44 \\
POVERTY & 7.18 & 1811.17 & 108.06 & 139.97 \\
ROADDEN & 2.90 & 46.80 & 15.41 & 7.41 \\
STROADDEN & 0.08 & 0.74 & 0.33 & 0.12 \\
NATAMER & 0.00 & 0.61 & 0.22 & 0.11 \\
GOVEX & -3.72 & 3.55 & 0.13 & 1.16 \\
PCTAX & 1168.00 & 33391.00 & 3791.97 & 2340.03 \\
PROPTAX & 43.00 & 1317.00 & 286.01 & 160.46 \\
CRIME & 22.20 & 99.10 & 72.54 & 17.17 \\
POP35_64 & 0.00 & 8487.00 & 2262.91 & 1556.56 \\
\hline & 27.78 & 47.08 & 39.60 & 2.29 \\
\hline
\end{tabular}

\subsection{MODEL ESTIMATION METHODS}

The estimation methods are drawn heavily from Greene (1996) and Wooldridge (2002). The system of simultaneous equations is a complete system of equations since the number of equations is equal to the number of endogenous variables. The reduced form implies that the model can be solved equation by equation given there are no restrictions on parameter space and that orthogonality holds for the error terms. However, to guarantee that the system of equations has unique solutions, the conditions for identification must be satisfied. These include the rank 
and order conditions. To satisfy the rank condition, the number of exogenous variables excluded from an equation should be equal or greater than the number of endogenous variables included in the equation. This is a necessary condition to ensure that the system has at least one solution. The rank condition requires that there is at least one non-zero determinant in the array of coefficients of the excluded variables which appears in the other equations. The rank condition ensures that there is exactly one solution for the structural parameters. In the model, there are more than one excluded variable in each equation, hence, both the order and rank conditions hold.

Ordinary least square (OLS) gives a biased and inconsistent estimate of the structural model if independent variables include endogenous variables. The simultaneity bias comes from the correlation between the right-hand side endogenous variable with the error terms. The models presented above imply simultaneity or reverse causation between dependent variables. Therefore, the estimation is done using two-stage least squares (2SLS) regression. 2SLS is a method used frequently to deal with endogenous variables. It uses instrumental variables that are uncorrelated with the error terms to compute estimated values of the problematic predictors in the first stage and then uses those computed values to estimate a linear regression model of the dependent variable in the second stage. Since the computed values are based on variables that are uncorrelated with the errors, the result of the two-stage estimation is optimal. 


\section{CHAPTER 5}

\section{EMPIRICAL ANALYSES AND RESULTS}

\subsection{EMPIRICAL ESTIMATION}

The growth model previously presented is estimated in three ways. First, the model presented using simultaneous equations is estimated using two-stage least squares regression (2SLS). This measures the simultaneous relationship between endogenous variables of population, employment and per capita income growth. The second estimation treats the equations as individual linear equations estimated using ordinary least squares regression (OLS) where dependent variables were strictly positioned on the left hand side of the equations and are regressed against exogenous variables. The third estimation, involves the constructed entrepreneurship index used as a dependent variable in the fourth equation in addition to the first

three equations of population growth, employment growth, and per capita income growth. The entrepreneurship index is tested for endogeneity and estimated as a fourth equation using 2-SLS.

Multicollinearity is addressed by dropping highly correlated variables from the results of Pearson correlation tests to increase efficiency of estimation while maintaining variables for estimating relevant variables. Durbin-Watson coefficients are all close to 2 indicating no problem of autocorrelation in model estimates.

The first estimation uses two-stage least squares regression (2-SLS) because estimation results using ordinary least squares regression when endogenous variables are used as explanatory variables are biased and inconsistent. The bias comes from the simultaneity relationship which leads to correlation between the right hand side endogenous variables and the error terms. The model is presented with implied theoretical simultaneity between the 
endogenous variables of population, employment, and per capita income. To account for the bias the model is estimated using 2SLS which provides consistent estimates of the model parameters.

The dependent variables are changes in population, employment, and per capita income. These are tested simultaneously against the right-hand side endogenous variables, their lagged values (initial conditions), and a set of other exogenous variables traditionally linked to economic growth. Parameter estimation was done using Statistical Packages for Social Sciences (SPSS) software. The results of two-stage least squares estimation is presented in Table 5.1.

To further the investigation of the relationship between entrepreneurship factors and measures of economic growth, the second estimation uses ordinary least squares regression (OLS). The equations in the model were estimated individually with growths in population, employment, and per capita income as individual dependent variables. Each measure of growth is regressed with strictly exogenous variables including their individual lagged values, measures of entrepreneurial activity, and a set of other variables. The results of OLS estimation are shown in Table 5.2.

The third estimation involves the use of two-stage least squares regression (2SLS) in estimating a four-equation model with changes in population, employment, per capita income, and an entrepreneurship index as endogenous variables. The entrepreneurship index represents the change in entrepreneurial activity constructed using principal component analysis. Selected variables used as measures of entrepreneurial activity in the previous estimations are used to construct an index that represents measures of entrepreneurship from the data on selfproprietorships and firm births. Principal component analysis is used to seek a linear combination of variables such that the maximum variance is extracted from the variables. The 
eigenvalues from the principal component analysis are presented in Table 5.1.1. Five measures of entrepreneurial activity are used to construct the entrepreneurship index. Change in the number of proprietors per 1000 labor force $\left(\mathrm{CHPROP}_{\mathrm{LF}}\right)$ has the strongest contribution in extraction with an eigenvalue of 1.606. This is followed by the change in the number of proprietors (CHPOP) with an eigenvalue of 1.471. Figure 5.1 shows the map of the constructed entrepreneurship index for Appalachia.

The theoretical simultaneity between the individual measures of growth and the entrepreneurship index is tested using Hausman test for endogeneity in the four-equation model. If entrepreneurship is endogenous, the equations are estimated using two-stage least squares (2SLS) regression to correct the endogeneity problem. The procedure for Hausman test is heavily drawn from Wooldridge (2002). The first step is a regression of the endogenous variable $\Delta$ En (entrepreneurship index) with all the exogenous variables. The residuals are then saved and included as an additional regressor in the estimation of the original equations. After running an OLS regression for each dependent variable (change in population, employment, and per capita income), a t-test for the coefficient of the first stage residuals is performed with a null hypothesis of no endogeneity. A p-value less than 0.10 indicates entrepreneurship index as endogenous. The results show that entrepreneurship is endogenous with population growth and employment growth but not with per capita income growth. Therefore, the population growth equation and employment growth equation are estimated while treating entrepreneurship also as endogenous. Since entrepreneurship is not endogenous with per capita income growth, the $\Delta \mathrm{I}$ equation is estimated with only population growth and employment growth used as endogenous variables. The results of Hausman test are summarized in Table 5.1.2. 
Table 5.1.1 Results of Principal Components Analysis

\begin{tabular}{lccc} 
Component & \multicolumn{3}{c}{ Eigenvalues } \\
\hline & Total & \% of Variance & Cumulative \% \\
\hline CHPROP $_{\mathrm{LF}}$ & 1.606 & 32.115 & 32.12 \\
CHPROP & 1.471 & 29.412 & 61.53 \\
CHBIRTH $_{\mathrm{LF}}$ & 0.970 & 19.395 & 80.92 \\
CHBIRTH & 0.538 & 10.762 & 91.68 \\
CHDEATH & 0.416 & 8.316 & 100.00 \\
\hline
\end{tabular}

Figure 5.1 Entrepreneurship Index for Appalachian Counties

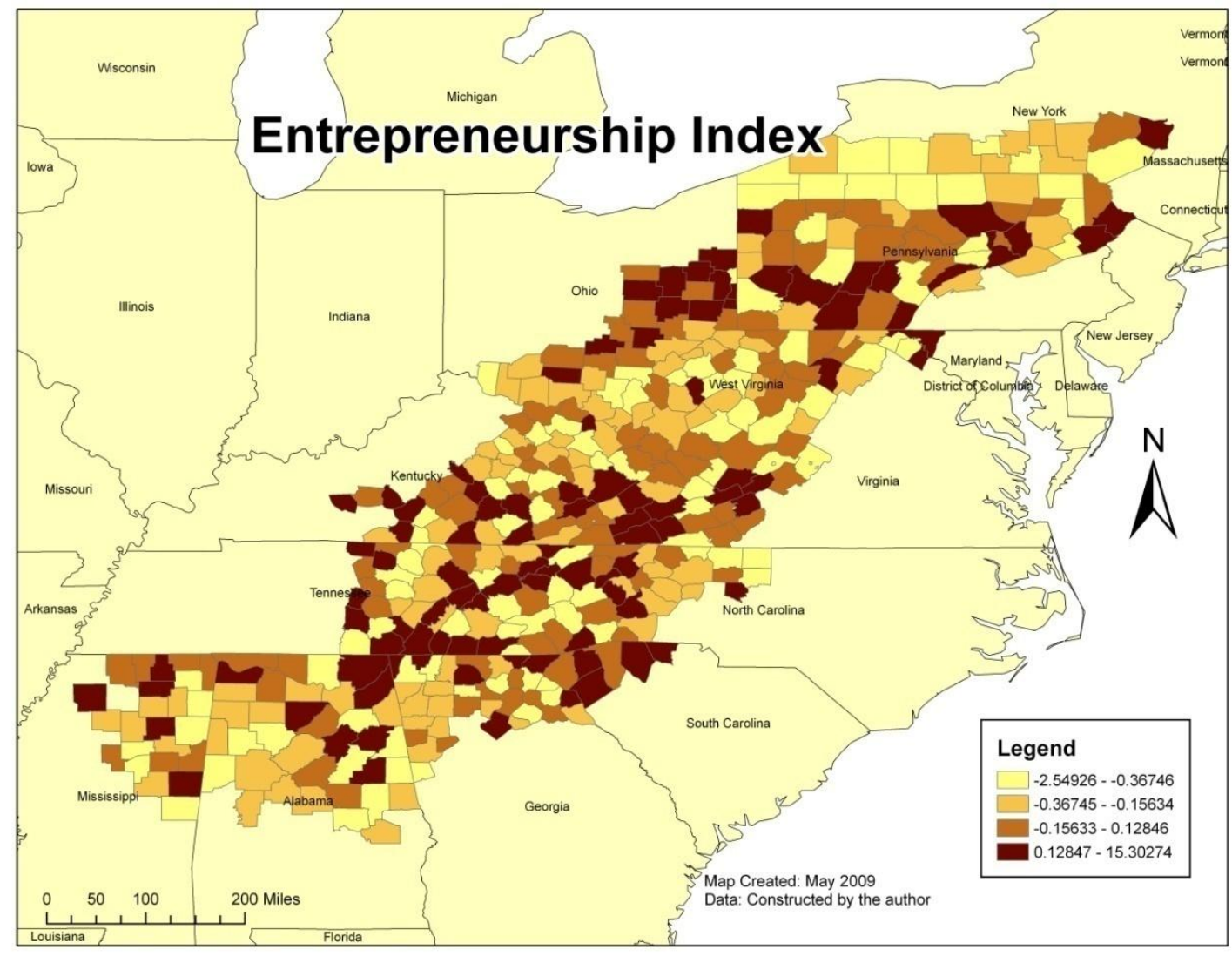


Table 5.1.2 Results of Hausman Test for Endogeneity.

Hausman statistic

p-value

Population equation

$0.112^{* *}$

0.017

Employment equation

$0.062 *$

0.077

Per capita income

0.037

0.403

***, **, * Significant at $1 \%, 5 \%$, and $10 \%$, respectively

\subsection{TWO-STAGE LEAST SQUARES (2-SLS) ESTIMATION RESULTS: THREE EQUATION GROWTH MODEL}

The first model estimation is done using two-stage least squares regression of the threeequation model. The results are shown in Table 5.2. The following section is a discussion of the results of the analysis where changes in population, employment and per capita income are estimated using the endogenous variables of growth, their lagged values, entrepreneurship variables, and a set of other variables linked to economic growth.

\subsubsection{Change in Population}

The population growth equation is regressed against its lagged value, the other two endogenous variables (employment growth and per capita income growth), entrepreneurship measures, and socio-demographic variables. Results show that change in population $(\Delta \mathrm{P})$ is significantly and positively associated with change in employment $(\Delta \mathrm{E})$. This supports the "people follow jobs" theory. That is, increases in the number of jobs result to increases in population. The relationship between change in population and per capita income $(\Delta \mathrm{I})$ is also statistically significant. However, the coefficient is negative indicating that for Appalachia, 
counties with increasing population have declining per capita income. This may be attributed to population increases in rural areas where income is not growing at least at the same rate as the population increases. The initial value of population growth $\left(\mathrm{P}_{\mathrm{t}-1}\right)$ exhibited a significant relationship with change in population and the sign of the coefficient is negative. Counties with lower initial populations showed increases in population growth supporting the theory of convergence where counties with low initial population levels tend to grow faster than regions with high initial populations.

In terms of entrepreneurship, population growth is significantly affected by the number of proprietors (PROP), number of firm births (BIRTH), change in the number of firm births (CHBIRTH), change in the number of firm deaths (CHDEATH), and number of firm deaths per 1000 people in the labor force $\left(\mathrm{DEATH} \mathrm{LF}_{\mathrm{LF}}\right)$. Variables representing entrepreneurial capacity are hypothesized to have a positive effect towards population change. This is supported by the positive coefficient in the BIRTH variable indicating that increases in the number of start up businesses increases population growth. The growth in the number of firm start ups (CHBIRTH) also showed a positive effect on change in population. Furthermore, the negative coefficient in CHDEATH variable supports the theory indicating that increases in the number of firm failures result to decreases in population. The negative sign in the $\mathrm{DEATH}_{\mathrm{LF}}$ variable also signify the negative effect of the increases in the number of firm deaths per 1000 labor force towards population growth. These results support the hypothesis that entrepreneurial opportunities attract people and that entrepreneurial capacity positively contributes to population growth. However, the sign of the coefficient for PROP is found to be negative. This may mean that agglomeration in terms of self-employment discourages people to move into an area. 
As a measure of agglomeration, population density (POPDEN) is found to significantly and positively affect change in population. As hypothesized, an increase in the number of people per square mile leads to increases in population. Percent of families below poverty level (POVFAM) is also found to be statistically significant in determining change in population. The negative sign of the coefficient indicate that counties with more families under poverty have declining population growth.

Miles of road per square mile (ROADDEN) is used to represent quality of infrastructure and is found to be positively affecting population growth. This supports the theory that better infrastructure attracts people towards a community. Contrary to expectations, the number of reported crimes per 100,000 population (CRIME) indicates a significant but positive coefficient. This may be attributed to the nature of crimes reported which do not actually affect migration decisions.

\subsubsection{Change in Employment}

The change in employment equation is estimated as a function of the endogenous variables - change in population $(\Delta \mathrm{P})$ and change in per capita income $(\Delta \mathrm{I})$, its lagged value $\left(\mathrm{E}_{\mathrm{t}-}\right.$ 1), the variables representing entrepreneurial capacity, and a set of additional variables linked to economic growth. Results are reported in Table 5.2.

Both endogenous variables used as explanatory variables are positive and statistically significant in determining employment growth. This supports the hypothesis tested in previous studies where population growth $(\Delta \mathrm{P})$, employment growth $(\Delta \mathrm{E})$, and per capita income growth $(\Delta \mathrm{I})$ have positive interactions. While holding other factors constant, the results suggest that an increase in population leads to a 0.45 increase in the number of people employed. The results in 
Table 5.2 show that "people follow jobs and jobs follow people". Also, an increase in number of people gives a \$ 0.08 increase in per capita income. Appalachian counties with higher income growth showed increases in employment growth. This supports Deller's (2001) extension of the Carlino and Mill's (1987) model where per capita income is hypothesized to positively drive employment change. Employment change is negatively related with its lagged value $\left(\mathrm{E}_{\mathrm{t}-1}\right)$. This means that counties with higher levels of employment growth had lower levels of employment initially. This supports prior results of the rural renaissance (Deller, et al., 2001) where counties that had higher levels of initial employment tended to experience lower rates of overall growth and development. 
Table 5.2 Two-Stage Least Squares (2SLS) Estimation Results (3-Equation Model).

\begin{tabular}{|c|c|c|c|c|c|c|}
\hline \multirow[b]{2}{*}{ Variable } & \multicolumn{2}{|c|}{ CHPOP Equation } & \multicolumn{2}{|c|}{ CHEMP Equation } & \multicolumn{2}{|c|}{ CHPCI Equation } \\
\hline & Coefficient & p-value & Coefficient & p-value & Coefficient & p-value \\
\hline \multicolumn{7}{|c|}{ Endogenous Variables } \\
\hline$\Delta \mathrm{P}$ & - & - & $0.4498 * * *$ & 0.0000 & $-0.3745^{* *}$ & 0.0232 \\
\hline$\Delta \mathrm{E}$ & $0.8519 * * *$ & 0.0000 & - & - & 0.2960 & 0.1447 \\
\hline$\Delta \mathrm{I}$ & $-0.1507 * * *$ & 0.0029 & $0.0801 * *$ & 0.0322 & - & - \\
\hline \multicolumn{7}{|c|}{ Initial Conditions } \\
\hline $\mathrm{P}_{\mathrm{t}-1}$ & $-0.6872 * * *$ & 0.0000 & - & - & - & - \\
\hline $\mathrm{E}_{\mathrm{t}-1}$ & - & - & $-0.7479 * * *$ & 0.0002 & - & - \\
\hline $\mathrm{I}_{\mathrm{t}-1}$ & - & - & - & - & $0.3541^{* * *}$ & 0.0000 \\
\hline \multicolumn{7}{|c|}{ Entrepreneurship Variables } \\
\hline PROP & $-0.6299 * * *$ & 0.0000 & $0.5299 * * *$ & 0.0000 & - & - \\
\hline PROPLF & 0.0069 & 0.7034 & 0.0022 & 0.8767 & 0.0709 & 0.1222 \\
\hline CHPROPLF & - & - & - & - & -0.0766 & 0.1616 \\
\hline CHPROP & - & - & $0.2129 * * *$ & 0.0000 & 0.1792 & 0.1161 \\
\hline BIRTLF & 0.0004 & 0.9773 & 0.0175 & 0.1420 & 0.0460 & 0.2618 \\
\hline CHBIRLF & -0.0065 & 0.7350 & - & - & - & - \\
\hline BIRTH & $0.8820 * * *$ & 0.0000 & $0.7239 * * *$ & 0.0023 & & \\
\hline CHBIRTH & $0.1095 * * *$ & 0.0000 & $0.0464 * *$ & 0.0317 & -0.0455 & 0.3883 \\
\hline CHEXPAND & - & - & $0.2787 * * *$ & 0.0009 & - & - \\
\hline CHDEATH & $-0.1045^{* * *}$ & 0.0001 & $-0.3322 * * *$ & 0.0002 & $-0.1173 *$ & 0.0594 \\
\hline DEATHLF & $-0.0278^{*}$ & 0.0849 & $0.0447 * * *$ & 0.0052 & -0.0046 & 0.9153 \\
\hline
\end{tabular}


Table 5.2 ontinued

\begin{tabular}{lcccccc}
\hline Other variables & & & & & \\
EDUC $_{\mathrm{HI}}$ & -0.0404 & 0.1522 & - & - & $0.1715^{* *}$ & 0.0329 \\
POPDEN & $0.0818^{*}$ & 0.0558 & - & - & - \\
METRO & - & - & 0.0012 & 0.9317 & -0.0204 & 0.6918 \\
POVFAM & $-0.1189 * * *$ & 0.0000 & $0.0526 * * *$ & 0.0082 & 0.0309 & 0.7075 \\
ROADDEN & $0.0375^{* *}$ & 0.0475 & -0.0219 & 0.1161 & 0.0451 & 0.5635 \\
STROADDEN & - & - & - & - & $-0.1208 *$ & 0.0985 \\
NATAMER & 0.0065 & 0.6714 & $-0.0464 * * *$ & 0.0004 & -0.0286 & 0.5257 \\
GOVEX & -0.0182 & 0.2120 & 0.0062 & 0.6076 & -0.0479 & 0.2591 \\
PCTAX & -0.0002 & 0.9899 & $0.0263 *$ & 0.0930 & -0.0741 & 0.2011 \\
PROPTAX & 0.0097 & 0.5481 & -0.0155 & 0.2486 & -0.0056 & 0.9074 \\
CRIME & $0.0352 *$ & 0.0583 & $-0.0343 * *$ & 0.0308 & -0.0211 & 0.7102 \\
POP35_64 & - & - & - & - & $0.0884 * *$ & 0.0535 \\
\hline
\end{tabular}

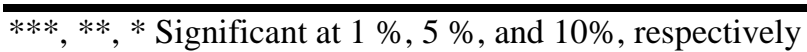


Most of the entrepreneurship variables used in the analysis is significant and all have the expected signs. The number of proprietors in 1995 (PROP) increases employment growth. This is also true for the variable measuring change in the number of proprietors between the years 1995 and 2005 (CHPROP). Increases in the number of self-employed have increased employment growth in Appalachian counties. Particularly, the coefficient for PROP means that an increase in the number of self-employed leads to a 0.53 increase in total employment. Furthermore, the coefficient of the number of firm births in 1995 (BIRTH) and the increase in the number of firm start-ups (CHBIRTH) have significant and positive coefficients. The coefficient for BIRTH indicates that an increase in the number of start up businesses leads to a 0.72 increase in the number of employed people. Furthermore, the variable which represents high-growth firms (CHEXPAND) also showed a positive and significant coefficient indicating that increases in firm expansion positively determines employment growth. These results support the hypothesis that entrepreneurial activity contributes positively towards employment growth. The variable $\mathrm{DEATH}_{\mathrm{LF}}$ is also significant; however, the sign is positive.

The share of families below poverty (POVERTY) is significant and negative which indicates that Appalachian counties with higher percentage of families under poverty had increases in employment. This could mean that counties with higher levels of poverty had more motivations to find employment resulting in increased job creation. Natural amenities rank (NATAMER) is found to be negative although significant in determining change in employment. This could mean that workers in Appalachia were attracted not through the natural amenities but through other factors that people prefer in choosing a place to work. Another consideration is the construction of the natural amenities scale. The scale is constructed using physical characteristics including climate, topography, and water area which may be biased towards the 
other regions of the United States. Per capita taxes (PCTAX) also had a significant relationship with employment growth; however, the sign is positive contrary to expectations. Taxes are hypothesized to discourage employment as people prefer lower taxes in their area of work. However, people also perform a cost-benefit analysis when weighing taxes against services (Deller et al., 2001). If services are perceived to be provided in an effective and efficient manner, people are willing to pay higher taxes. The number of reported crimes per 100,000 people (CRIME) is negative and significant as hypothesized. This shows that increases in crime rates discourage employment growth.

\subsubsection{Change in Per Capita Income}

As further shown in Table 5.2, the per capita income $(\Delta \mathrm{I})$ equation is regressed against its lagged value $\left(\mathrm{I}_{\mathrm{t}-1}\right)$, population growth $(\Delta \mathrm{P})$ and employment growth $(\Delta \mathrm{E})$, entrepreneurship measures, and a set of socio-demographic variables. Change in population $(\Delta \mathrm{P})$ is significant but the sign is negative. This means that for Appalachia, counties with higher levels of population had declining per capita income. This is the same observation with the change in population equation which could mean that rural counties in Appalachia had per capita income growth rates that did not rise as quickly as population growth rates. Per capita income in $1995\left(\mathrm{I}_{\mathrm{t}-1}\right)$ is significant and positive. This means that counties with higher levels of per capita income in the beginning of the period (1995) had increases in the level of per capita income growth between 1995 and 2005. The coefficient specifically indicates that a dollar increase in per capita income in 1995 results to $\$ 0.35$ growth in per capita income.

In terms of entrepreneurial activity, change in the number of firm deaths (CHDEATH) is found to be significant and has a negative coefficient as expected. This means that a higher 
level of firm failure leads to declining per capita income. The coefficient indicates that an increase in CHDEATH results to a $\$ 0.12$ reduction in per capita income.

The variable used to represent the quality of human capital $\left(\mathrm{EDUC}_{\mathrm{HI}}\right)$ had a positive sign as hypothesized. A higher share of population with high school education indicates a higher quality of the labor force. The coefficient suggests that a one percent increase in the share of population with high school education results to a $\$ 0.17$ increase in per capita income. Miles of state road per square mile (STROADDEN) is significant but negative. The share of population 35 to 64 years old (POP35_64) is also significant and positive as expected. This portion of the population is usually the most productive and is theorized to increase per capita income. The result indicates that an increase in the proportion of the productive age of population results to a \$0.09 increase in per capita income.

\subsection{ORDINARY LEAST SQUARES (OLS) ESTIMATION RESULTS: THREE EQUATION GROWTH MODEL}

To further the investigation of the relationship between entrepreneurial capacity and economic growth, the three-equation model is estimated using the method of ordinary least squares (OLS) regression. Endogeneity is not an issue in this estimation as endogenous variables

in the model are strictly treated as dependent variables. Endogeneity is only an issue if endogenous variables are used as explanatory variables. Measures of population, employment, and per capita income growth are estimated against exogenous variables. The following is a discussion of the results as shown in Table 5.3. 


\subsubsection{Change in Population}

Using OLS, the change in population $(\Delta \mathrm{P})$ equation is regressed against its lagged value $\left(\mathrm{P}_{\mathrm{t}-1}\right)$, the variables used to represent entrepreneurial activity, and a set of other variables linked to economic growth. As the results in Table 5.3 shows, population in $1995\left(\mathrm{P}_{\mathrm{t}-1}\right)$ is statistically significant and negative as hypothesized.

Entrepreneurial factors such as the number of self-employed in 1995 (PROP), change in the number of firm births per 1000 people in the labor force $\left(\mathrm{CHBIRTH}_{\mathrm{LF}}\right)$, number of start-up businesses in 1995 (BIRTH), growth in firm births (CHBIRTH), growth in firm expansion (CHEXPAND), and the number of firm deaths per 1000 people in the labor force $\left(\mathrm{DEATH}_{\mathrm{LF}}\right)$ are found to be statistically significant in determining population growth in the counties of Appalachia. The number of start-ups (BIRTH) has a positive coefficient indicating that increases in the number of firm births increases population. Growth in firm births (CHBIRTH) also had a positive sign. Furthermore, the coefficient for the DEATHLF is negative which means that an increase in the number of firm failure decreases population growth. These results support the theory of the positive relationship between entrepreneurship and population growth.

Additional variables such as the share of population with high school education $\left(\right.$ EDUC $\left._{\mathrm{HI}}\right)$, population per square mile (POPDEN), the dummy variable identifying metro and non-metro counties (METRO), percent of families below poverty (POVERTY), miles of state road per square mile (STROADDEN), government expenditure (GOVEX), property taxes (PROPTAX), and share of population 35 to 64 years old (POP35_64) are statistically significant in determining population change. Education is hypothesized to positively affect measures of economic growth. However, in this case, education is negatively affecting change in population. This can be attributed to the share of educated population migrating to other counties to work. 
As a measure of agglomeration, population density (POPDEN) has a positive coefficient, as expected. This signifies that counties with high densities of population tend to have higher growths in population. This is further supported by the positive coefficient of the METRO variable showing that population increases as the county becomes urbanized. Percent of families under poverty (POVERTY) has a negative coefficient as hypothesized which means that increasing rates of poverty discourages people to reside in a community, therefore reducing population growth.

As a measure of quality of infrastructure, miles of state road per square mile (STROADDEN) has a positive relationship with change in population. The figure supports the notion that increased quality of infrastructure is one of the factors that attract people to reside in a community. The coefficient for property taxes (PROPTAX) is negative indicating that taxes have an inverse relationship with change in population. However, the coefficient for government expenditure per capita (GOVEX) is negative which is contrary to the hypothesis that increased government expenditure leads to increased welfare in society which should therefore attract people and increase population growth. The share of population 35 to 64 years old also had a negative sign which was not expected.

Compared to previous results using two-stage least squares (2SLS) regression, OLS results further support the positive relationship between entrepreneurial activity and population growth. Entrepreneurship variables constructed from data on firm births are mostly significant in both 2-SLS and OLS estimation results. Population density, the poverty measure, and variables representing infrastructure quality are also significant in both methods of analysis. 


\subsubsection{Change in Employment}

OLS regression is used to estimate the employment growth $(\Delta \mathrm{E})$ equation against its lagged value $\left(\mathrm{E}_{\mathrm{t}-1}\right)$, the entrepreneurship variables, and a set of other variables. The results in Table 5.3 show a significant and negative relationship between change in employment and its lagged value. Most of the entrepreneurship variables are statistically significant in determining employment growth. The number of proprietors in 1995 (PROP) has a positive relationship with employment change as well the change in the number of self-employed between 1995 and 2005 (CHPROP). These results mean that increases in the number of self-employed increases employment in Appalachian counties. Specifically, an increase in the number of proprietors in 1995 has increased total employment by 0.29 and growth in proprietorship resulted to an increase of 0.31 in total employment. On the other hand, the coefficient for the change in the number of proprietors per 1000 people in the labor force is negative.

Measures of entrepreneurial capacity from firm birth data are also found to have significant relationships with employment growth. The number of firm births in 1995 (BIRTH) is significant and positive showing that an increase in the number of start-ups resulted in a 1.77 increase in total employment. The number of firm births per 1000 people in the labor force $\left(\mathrm{BIRTH}_{\mathrm{LF}}\right)$ has a positive coefficient indicating the contribution of increases in firm births to total employment. Furthermore, the growth in firm births (CHBIRTH) also has a positive and significant coefficient indicating the role of the increase in firm births on employment change. The results also show the positive relationship between high-growth firms and total employment as the variable CHEXPAND is significant and positive. The coefficient means that a firm expansion leads to a 0.25 increase in total employment. In addition, the number of firm deaths per 1000 people in the labor force $\left(\mathrm{DEATH}_{\mathrm{LF}}\right)$ and the growth in the number of firm deaths 
(CHDEATH) has significant and negative coefficients as hypothesized. These figures support the theory on the role of entrepreneurship in increasing employment growth. However, the sign of the coefficient for change in the number of business start-ups per 1000 people in the labor force $\left(\mathrm{CHBIRTH} \mathrm{H}_{\mathrm{LF}}\right)$ is negative.

As hypothesized, population density (POPDEN) is significant and positively affects changes in employment. The figure means that an additional person per square mile contributes 0.12 in total employment. Property tax (PROPTAX) is significant and negative as hypothesized. Taxes are expected to have a negative relationship with total employment as it reduces demand for consuming goods and services as well as reducing firm profits. However, the coefficient for per capita tax (PCTAX) is positive. This could mean that property taxes are the only ones that actually discourage employment growth. The number of reported crimes per 100,000 people (CRIME) is significant and negative as expected. However, the share of population 35 to 64 years old (POP35_64) and the variable for natural amenities rank (NATAMER) have negative coefficients.

Compared to the results of the two-stage least squares (2-SLS) regression, the result of OLS shows similar results where entrepreneurship variables are significant and generally have positive relationships with employment growth. The results of the both estimation methods strengthen the evidence of the role of entrepreneurial capacity in increasing total employment. They also have similar results in terms of natural amenities, per capita taxes, and number of crimes reported. 


\subsubsection{Change in Per Capita Income}

The change in per capita income $(\Delta \mathrm{I})$ equation is also estimated using ordinary least squares (OLS) regression as a function of its lagged value $\left(\mathrm{I}_{\mathrm{t}-1}\right)$, the entrepreneurship variables, and other variables linked to economic growth. The results presented in Table 5.3 show that the value of per capita income in $1995\left(\mathrm{I}_{\mathrm{t}-1}\right)$ is significant and positive in determining per capita income growth. This suggests that counties with higher level of per capita income initially had high per capita income growth.

In terms of entrepreneurship, the number of self-employed in 1995 (PROP) has a significant and positive relationship with per capita income growth. The figure shows that an increase in the number of proprietors leads to a $\$ 0.35$ increase in per capita income, other things held constant. In addition, growth in proprietorship (CHPROP) is significant and positive indicating the contribution of self-employment growth on change in per capita income. In particular, all other factors held constant, the coefficient shows that a one proprietor increase leads to a $\$ 0.28$ increase in per capita income.

The quality of human capital represented by percent of population with high school education $\left(\mathrm{EDUC}_{\mathrm{HI}}\right)$ is significant and positive. This supports the theory on the role of human capital in increasing income. The share of population 35 to 64 years is also significant and positive as hypothesized. This portion of the population is the most productive and has a significant role in increasing per capita income. On the other hand, miles of state road per square mile (STROADDEN) are negative contrary to expectations.

The results of two-stage least squares (2-SLS) and ordinary least squares (OLS) regressions both show the positive and significant contribution of the initial value of per capita income on change in per capita income. Some of the entrepreneurship variables are significant in both 
Table 5.3 Ordinary Least Squares (OLS) Estimation Results.

\begin{tabular}{|c|c|c|c|c|c|c|}
\hline \multirow[b]{2}{*}{ Variable } & \multicolumn{2}{|c|}{ CHPOP Equation } & \multicolumn{2}{|c|}{ CHEMP Equation } & \multicolumn{2}{|c|}{ CHPCI Equation } \\
\hline & Coefficient & p-value & Coefficient & p-value & Coefficient & p-value \\
\hline \multicolumn{7}{|c|}{ Initial Conditions } \\
\hline$P_{t-1}$ & $-1.7770 * * *$ & 0.0000 & - & - & - & - \\
\hline $\mathrm{E}_{\mathrm{t}-1}$ & - & - & $-1.5750 * * *$ & 0.0000 & - & - \\
\hline $\mathrm{I}_{\mathrm{t}-1}$ & - & - & - & - & $0.3380 * * *$ & 0.0000 \\
\hline \multicolumn{7}{|c|}{ Entrepreneurship Variables } \\
\hline PROP & $-0.3020 *$ & 0.0950 & $0.2920 * * *$ & 0.0110 & $0.3500^{*}$ & 0.0820 \\
\hline PROPLF & 0.0340 & 0.1600 & 0.0200 & 0.2820 & 0.0220 & 0.6550 \\
\hline CHPROPLF & -0.0390 & 0.1090 & $-0.0480 * * *$ & 0.0130 & -0.0910 & 0.1050 \\
\hline CHPROP & 0.0580 & 0.1320 & $0.3110 * * *$ & 0.0000 & $0.2810 * * *$ & 0.0010 \\
\hline BIRTLF & 0.0170 & 0.3570 & $0.0310 * *$ & 0.0380 & 0.0510 & 0.2290 \\
\hline CHBIRLF & $-0.0820 * *$ & 0.0010 & $-0.0570 * * *$ & 0.0030 & -0.0830 & 0.1180 \\
\hline BIRTH & $2.1270 * * *$ & 0.0000 & $1.7740 * * *$ & 0.0000 & -0.2530 & 0.1790 \\
\hline CHBIRTH & $0.2770 * * *$ & 0.0000 & $0.1600 * * *$ & 0.0000 & -0.0500 & 0.3770 \\
\hline CHEXPAND & $-0.4670 * * *$ & 0.0010 & $0.2350 * *$ & 0.0270 & 0.2840 & 0.3450 \\
\hline CHDEATH & 0.2080 & 0.1260 & $-0.4070 * * *$ & 0.0000 & -0.0030 & 0.3460 \\
\hline DEATHLF & $-0.0910 * * *$ & 0.0000 & $-0.0900 * * *$ & 0.0000 & -0.0030 & 0.9530 \\
\hline
\end{tabular}


Table 5.3 continued

\section{Other variables}

\begin{tabular}{|c|c|c|c|c|c|c|}
\hline $\mathrm{EDUC}_{\mathrm{HI}}$ & $-0.0650 *$ & 0.0610 & -0.0010 & 0.9700 & $0.2710 * * *$ & 0.0010 \\
\hline POPDEN & $0.1980 * * *$ & 0.0010 & $0.1150 * * *$ & 0.0140 & -0.1660 & 0.2180 \\
\hline METRO & $0.0730 * * *$ & 0.0030 & -0.0020 & 0.9130 & -0.0050 & 0.9290 \\
\hline POVFAM & $-0.0950 * * *$ & 0.0030 & 0.0100 & 0.6900 & 0.1080 & 0.1960 \\
\hline ROADDEN & -0.0570 & 0.1530 & -0.0500 & 0.1080 & 0.0880 & 0.3240 \\
\hline STROADDEN & $0.0780^{* *}$ & 0.0210 & 0.0080 & 0.7740 & $-0.1450 *$ & 0.0600 \\
\hline NATAMER & -0.0250 & 0.2120 & $-0.0570 * * *$ & 0.0010 & -0.0320 & 0.4860 \\
\hline GOVEX & $-0.0320^{*}$ & 0.1040 & 0.0020 & 0.9050 & -0.0440 & 0.3200 \\
\hline PCTAX & 0.0110 & 0.6910 & $0.0370^{*}$ & 0.0800 & -0.0760 & 0.2070 \\
\hline PROPTAX & $-0.0370 *$ & 0.0910 & $-0.0350 * *$ & 0.0440 & -0.0160 & 0.7560 \\
\hline CRIME & 0.0150 & 0.5630 & $-0.0410 * *$ & 0.0440 & -0.0450 & 0.4390 \\
\hline POP35_64 & $-0.0380 *$ & 0.0670 & $-0.0410 * * *$ & 0.0120 & $0.0980 * *$ & 0.0400 \\
\hline $\mathrm{R}^{2}$ & 0.8710 & & 0.9190 & & 0.3380 & \\
\hline
\end{tabular}

***, **, * Significant at $1 \%, 5 \%$, and $10 \%$, respectively 
methods and supports the hypothesis of the positive relationship between entrepreneurship and income growth. Education, state road density, and the share of productive population are significant in affecting per capita income growth in both methods of estimation.

\subsection{TWO-STAGE LEAST SQUARES ESTIMATION (2-SLS) RESULTS: FOUR- EQUATION GROWTH MODEL}

This section of the study is a discussion of the results in estimating the four-equation model where an entrepreneurship index is added to the original three-equation model of growth. The index is constructed using principal component analysis and tested for endogeneity against population growth, employment growth, and per capita income growth using the Hausman test. The result is a four-equation model where entrepreneurial growth is also estimated against other endogenous variables in the model as well as exogenous variables. The results are presented in Table 5.4.

\subsubsection{Change in Population}

The result of Hausman test reveals that entrepreneurship is endogenous with population growth. Therefore, to account for the endogeneity issue, the structural equation is estimated using two-stage least squares (2-SLS) estimation. Population growth $(\Delta \mathrm{P})$ is regressed against the endogenous variables - change in employment $(\Delta \mathrm{E})$, change in per capita income $(\Delta \mathrm{I})$ and change in entrepreneurship $(\Delta \mathrm{En})$, its lagged value $\left(\mathrm{P}_{\mathrm{t}-1}\right)$, and other variables linked to economic growth. The results in Table 5.4 show that employment growth $(\Delta \mathrm{E})$ is positive and significantly affecting population growth. This supports the result of the 2-SLS estimation in the threeequation model. The coefficient indicates that an increase in total employment leads to a 1.5 
increase in population. This supports the theory of the positive interaction between population growth and employment growth as hypothesized in previous studies.

The lagged value of population is significant and the sign of the coefficient is negative, as found in the regression estimate of the three-equation model. This means that counties with lower initial population had higher population growth and further supports the hypothesis. The education variable is also negative which means that counties with a higher proportion of the population with high school education had lower rates of population increase. The coefficient for miles of road per square mile (ROADDEN) is significant and positive as expected. This supports the theory of the positive effect of better quality infrastructure in attracting people and verifies the result in the three-equation model. The figure shows that a mile increase of road per square mile results to a 0.05 increase in population.

Compared to the three-equation model estimation, the 4-equation model revealed fewer significant variables. The three-equation model determined most of the firm birth variables to be significant in addition to the poverty and crime measures. Estimation using ordinary least squares (OLS) regression also showed more significant variables in determining population growth.

\subsubsection{Change in Employment}

Using two-stage least squares (2-SLS) estimation, the change in employment $(\Delta \mathrm{E})$ equation is regressed against the endogenous variables - population growth $(\Delta \mathrm{P})$, per capita income growth $(\Delta \mathrm{I})$, and entrepreneurship $(\Delta \mathrm{En})$, its initial value $\left(\mathrm{E}_{\mathrm{t}-1}\right)$, and a set of socioeconomic variables. The results in Table 5.4 indicate a significant and positive relationship between population growth and employment growth which supports the "people follow jobs" 
hypothesis and further confirms the result in the three-equation model. Specifically, an increase in population gives a 0.98 increase in employment. Other variables used in the estimation are not statistically significant.

\subsubsection{Change in Per Capita Income}

Since the result of endogeneity test revealed that per capita income growth is not endogenous with entrepreneurship, the $\Delta \mathrm{I}$ equation is estimated as a function of the endogenous variables- population growth and employment growth, its lagged value $\left(\mathrm{I}_{\mathrm{t}-1}\right)$, a set of other variables linked to economic growth and entrepreneurial growth which is treated as an exogenous variable. The results show a significant and positive relationship between per capita income growth and its lagged value. This indicates that Appalachian counties with higher growth in per capita income initially had higher per capita income.

The education variable also has a significant and positive coefficient supporting the hypothesis of the contribution of education in increasing income and the result in the threeequation model estimation. The result indicates that a percentage increase in population with high school education increases per capita income by $\$ 0.16$.

\subsubsection{Change in Entrepreneurial Activity}

The constructed entrepreneurship index $(\Delta \mathrm{En})$ is tested for endogeneity against three measures of growth - population growth $(\Delta \mathrm{P})$, employment growth $(\Delta \mathrm{E})$, and per capita income growth $(\Delta \mathrm{I})$. The result of Hausman test showed that entrepreneurship is endogenous with population growth and employment growth, but not with per capita income growth. Therefore, the entrepreneurship equation $(\Delta \mathrm{En})$ is estimated as a function of the endogenous variables - 
change in population and change in employment and the set of variables traditionally linked to economic growth. The results in Table 5.4 indicate a significant and positive relationship between growth in entrepreneurial activity and employment growth. This provides evidence on the role of entrepreneurship in increasing job creation. The coefficient for population growth is also statistically significant; however, the sign is negative which is contrary to hypothesis. This means that counties with lower population increases had higher growths in entrepreneurial activity. The per capita income variable $(\Delta \mathrm{I})$, treated as exogenous, is also found to be significant in determining entrepreneurial growth. However, the coefficient is negative. 
Table 5.4 Estimation Results of 4-Equation Model.

\begin{tabular}{|c|c|c|c|c|c|c|c|c|}
\hline \multirow[b]{2}{*}{ Variable } & \multicolumn{2}{|c|}{ CHPOP Equation } & \multicolumn{2}{|c|}{ CHEMP Equation } & \multicolumn{2}{|c|}{ CHPCI Equation } & \multicolumn{2}{|c|}{ ENTREP Equation } \\
\hline & Coefficient & p-value & Coefficient & p-value & Coefficient & p-value & Coefficient & p-value \\
\hline \multicolumn{9}{|c|}{ Endogenous Variables } \\
\hline$\Delta \mathrm{P}$ & - & - & $0.981^{*}$ & 0.074 & -0.319 & 0.433 & $-0.534 * * *$ & 0.004 \\
\hline$\Delta \mathrm{E}$ & $1.543 * * *$ & 0.000 & - & - & 0.143 & 0.588 & $1.340 * * *$ & 0.000 \\
\hline$\Delta \mathrm{I}$ & 0.127 & 0.296 & -0.141 & 0.628 & - & - & - & - \\
\hline$\Delta \mathrm{En}$ & -0.126 & 0.472 & -0.401 & 0.583 & - & - & - & - \\
\hline \multicolumn{9}{|c|}{ Initial Conditions } \\
\hline$P_{t-1}$ & $-0.850 * * *$ & 0.000 & - & - & - & - & - & - \\
\hline $\mathrm{E}_{\mathrm{t}-1}$ & - & - & 1.107 & 0.253 & - & - & - & - \\
\hline $\mathrm{I}_{\mathrm{t}-1}$ & - & - & - & - & $0.455 * * *$ & 0.000 & - & - \\
\hline \multicolumn{9}{|l|}{ Other variables } \\
\hline$\Delta \mathrm{I}$ & - & - & - & - & - & - & $-0.127 * *$ & 0.024 \\
\hline$\Delta \mathrm{En}$ & - & - & - & - & 0.038 & 0.744 & - & - \\
\hline $\mathrm{EDUC}_{\mathrm{HI}}$ & $-0.103 *$ & 0.064 & 0.096 & 0.291 & $0.161 * *$ & 0.038 & -0.088 & 0.123 \\
\hline POPDEN & - & - & - & - & - & - & - & - \\
\hline METRO & - & - & - & - & - & - & -0.072 & 0.155 \\
\hline POVFAM & - & - & - & - & 0.039 & 0.662 & - & - \\
\hline ROADDEN & $0.051^{*}$ & 0.091 & - & - & - & - & - & - \\
\hline STROADDEN & & & - & - & - & - & 0.005 & 0.891 \\
\hline NATAMER & 0.039 & 0.170 & - & - & - & - & - & - \\
\hline GOVEX & - & - & - & - & -0.046 & 0.408 & - & - \\
\hline PCTAX & 0.013 & 0.691 & -0.009 & 0.792 & -0.076 & 0.230 & 0.015 & 0.779 \\
\hline PROPTAX & 0.044 & 0.151 & - & - & - & - & - & - \\
\hline CRIME & - & - & -0.152 & 0.433 & - & - & - & - \\
\hline POP35_64 & - & - & 0.007 & 0.886 & - & - & - & - \\
\hline
\end{tabular}




\section{CHAPTER 6}

\section{SUMMARY AND CONCLUSIONS}

\subsection{SUMMARY AND CONCLUSIONS}

The main objective of this study is to determine the relationship between regional growth and entrepreneurship. Entrepreneurship has been observed to be positively linked to economic growth. It has received significant attention from the literature as a strategy for communities to alleviate poverty and achieve economic growth and development. New businesses and self employment contribute new jobs resulting in higher income levels and increased wealth. With new business formations and the growth of existing ones, entrepreneurship leads to increased welfare in the society.

To examine the role of entrepreneurship in economic growth, this study used a regional economic growth model using a system of simultaneous equations. Data on 410 counties of Appalachia are employed where measures of entrepreneurial activity are constructed and regressed against measures of economic growth. Appalachia is chosen for the study as the region is characterized by underdevelopment and poverty. It was concluded to be different from the other parts of the US because of its geographical location and its social and economic development status relative to other regions of the country. Appalachia provides an ideal study area to investigate the relationship between entrepreneurial capacity and economic growth.

This study adopts the use of regional economic growth models in examining the relationship between entrepreneurship and economic growth. The simultaneous equation model is used where the dynamics of population growth, employment growth, and per capita income growth is utilized to determine how regional factors affect patterns of growth. In this study, the 
focus is how entrepreneurial factors influence growth in population, employment, and per capita income. The three-equation growth model is empirically estimated using the methods of twostage least squares (2-SLS) and ordinary least squares (OLS) regressions. Simultaneous equations are estimated using 2-SLS to account for the endogeneity issue in variables used as both dependent and explanatory variables. These variables include the measures of growth and the constructed entrepreneurship index.

The entrepreneurship index is constructed from selected measures of entrepreneurial activity using principal component analysis (PCA). PCA is employed to seek a linear combination of five entrepreneurship variables to come up with a single measure of entrepreneurial capacity. The index is used as a dependent variable in the four-equation growth model to determine simultaneous relationships between entrepreneurship and the measures of economic growth. The Hausman test is used to determine causal relationships between the entrepreneurship index and the growth measures. Results reveal that entrepreneurship is endogenous with population growth and employment growth, but not with per capita income growth. Therefore, the population growth equation is estimated while entrepreneurship as an endogenous variable and empirically estimated using instrumental variables. The employment growth equation is estimated the same way. However, since entrepreneurship is exogenous with per capita income growth, the per capita income equation and the entrepreneurship equation are empirically estimated while treating per capita income and entrepreneurship as exogenous.

The results from the three model specifications generally support the main hypothesis tested in the study, showing evidence on the positive effects of entrepreneurial activity towards economic growth. The empirical results of the three-equation model using both two-stage least squares (2-SLS) and ordinary least squares (OLS) regressions provide practical support for the 
theory. However, estimating the four-equation model, where an entrepreneurship index is constructed and treated as an endogenous did not show significant relationships between entrepreneurship and the measures of economic growth.

Estimating the change in population equation shows that counties with increasing employment experience increasing population growth. In terms of entrepreneurship, estimating the three-equation model using both 2-SLS and OLS methods show that population growth is positively affected by entrepreneurship variables constructed from firm births data. The number of firm births and the growth in firm births positively determine population growth in Appalachian counties. In addition, firm death is found to negatively affect change in population. However, the entrepreneurship index did not show significant effects towards population growth in estimating the four-equation model. While population density and quality of infrastructure, increase county population, percentage of families below poverty level, education, and the initial value of population have negative effects towards population growth. The OLS estimation of the three-equation model also shows a positive effect of the degree of urbanization and a negative effect of property taxes on growth in population.

The empirical results in estimating the change in employment equation in both three and four-equation models indicate that growth in population is positively related with employment growth. From the results in estimating the population and employment growth equations, this study further supports the "jobs follow people and people follow jobs" theory. The threeequation model results using 2-SLS also show that employment growth and per capita income growth are positively related. Entrepreneurship variables constructed from self-employment and firm data are found to have positive effects in determining increases in county employment. The results in estimating the three-equation model using 2-SLS and OLS both indicate that self- 
employment, the growth in the number of self-employed, start-up businesses, the growth in startups, and the growth in firm expansion positively determine employment growth in Appalachia. Firm death is found to negatively affect employment which further supports the theory on the role of entrepreneurship in increasing job creation. Crime rate in the three-equation model is also found to reduce job creation both in 2-SLS and OLS results. However, both estimation methods indicate negative relationships between natural amenities ranking and employment growth which is in contrast to the hypothesized relationship. Furthermore, per capita taxes show positive effects in county employment growth. OLS results also show a positive effect of population density and negative effects of property taxes and the share of population 35 to 64 years old towards employment growth.

Empirical results in estimating the per capita income equation using 2-SLS in the threeequation model show that population growth negatively affects increases in per capita income. The initial value of per capita income is found to be positive in determining per capita income growth in all three estimations. In terms of entrepreneurship, the 2-SLS estimation of the threeequation model indicates a negative relationship between growth in firm deaths and per capita income growth. The OLS estimation revealed that increases in the number of self-employed and increases in per capita income are related. The lagged value of per capita income growth is positive in relation to per capita income growth in all three estimations. In addition, the hypothesis on the positive effects of education in increasing income is proved in all three estimations. While the results of 2-SLS and OLS estimations of the three-equation model show positive relationships between the share of population 35 to 64 years old and per capita income growth, negative relationships exist between state road density and change in per capita income. The estimation of the entrepreneurship equation in the four-equation model shows significant 
relationships with all the other endogenous variables. However, a positive association is observed only between the employment growth and the growth in entrepreneurial activity.

\subsection{POLICY RECOMMENDATIONS}

Based on empirical results of the relationship between entrepreneurship and regional economic growth, the following are recommendations that will help achieve economic growth and development in Appalachia:

1. An entrepreneurial environment may be created to encourage entrepreneurial activity as a strategy to battle unemployment. One major finding of this study in support to the results of previous studies is that increases in entrepreneurial activity, particularly increases in selfemployment and firm births significantly contribute to employment growth. One of the main contributions of entrepreneurship is job creation which is further proved in this study and should be used as a strategy to increase employment in the counties of Appalachia. The greatest gains in entrepreneurship can be realized by reducing government-imposed burdens on entrepreneurs and through programs that encourage entrepreneurial activities, i.e., subsidies and tax breaks.

2. Supporting existing entrepreneurs and avoiding firm deaths may help in achieving economic growth. Since the findings of this study indicate that firm expansion and deaths were found to significantly affect regional economic growth, supporting existing firms in achieving expansions and avoiding failures may help in attaining growth in Appalachian communities. This may be done by creating programs that will help educate entrepreneurs on how to survive in today's market conditions and how to achieve growth in their businesses. 
3. Increasing the quality of human capital through higher education could be effective in achieving growth. A higher quality of the labor force is expected to be more efficient and therefore reduces the average cost of the business leading to a higher employment and income growth. The education factor is determined to be a major determinant in all the methods of analyses used in the study providing strong evidence on the implication of increased education in increasing income.

\subsection{LIMITATIONS AND FUTURE RESEARCH}

\subsubsection{Limitations of the Study}

This study has expanded the examination of the determinants of regional economic growth by adding entrepreneurship factors in a regional model using simultaneous equations. However, improvements in the study can be done considering its limitations. The first limitation is in the construction of the entrepreneurship index. Exploring ways to construct the index would affect the results of the estimations and using different combinations of data that measure entrepreneurial activity will give different estimates that will facilitate comparison of results.

The second limitation is in the choice of variables included in the analyses. For example, additional amenity indicators could have been used in the estimation and/or other measures of amenity endowment could have been explored to enhance the performance of the models. Using different measures of the factors linked to economic growth can help in comparing results towards a more robust estimation. 


\subsubsection{Recommendations for Future Studies}

The above limitations can provide opportunities for the improvement and expansion of the study in the future. In addition, several aspects of the study can be expanded to further the investigation of the link between entrepreneurship and economic growth. First, the effects of entrepreneurial activity can be further investigated by industry. For example, variables representing self-employment, firm births, and firm deaths in different industries such as manufacturing, construction, trade, transportation, and other sectors can be integrated in future work to extend the examination of the effects of entrepreneurship in the economy. Particularly, this will categorize the contribution of entrepreneurial activity from different sectors and will identify the industries that contribute towards the achievement of economic growth.

Second, the model can be specified as a spatial econometric model to incorporate the role of space in examining the relationship entrepreneurship in economic growth. Spatial distribution of economic activity has received great interest from economists concerned with location decisions, urban growth, regional growth, land use change, and other areas of regional studies. Integrating spatial aspects in the analyses will determine spatial dependence in regional growth patterns and capture spillover effects.

Third, the study could be extended to a national-level analysis to increase variation in the data through increased sample size. Furthermore, increasing the scope of the study will yield insights on a greater perspective with more general applications. 


\section{REFERENCES}

Acs, Zoltan J., 2006, “How is Entrepreneurship Good for Economic Growth?” Innovations 1(1), 97-107.

Acs, Zoltan J. and Catherine Armington, 2004, "The Impact of Geographic Differences in Human Capital on Service Firm Formation Rates," Journal of Urban Economics 56, 244-278.

Acs, Zoltan J. and Catherine Armington, 2005, "Using Census BITS to Explore Entrepreneurship, Geography, and Economic Growth," Small Business Research Summary No. 248, U.S. Small Business Administration's Office of Advocacy.

Acs, Zoltan J. and Catherine Armington, 2006, Entrepreneurship, Geography, and American Economic Growth, Cambrige University Press, New York, NY.

Acs Zoltan J. and David B. Audretsch, 1987, "Innovation, Market Structure and Firm Size," Review of Economics and Statistics 69, 567-574.

Acs, Zoltan J., David Audretsch B., and Maryann P. Feldman, 1994, "R\&D Spillovers and Recipient Firm Size," The Review of Economics and Statistics, 76(2), 336-340.

Acs, Zoltan J. and Attila Varga, 2002, "Geography, Endogenous Growth and Innovation, International Regional Science Review," 25, 132-148.

Acs, Zoltan J., David B. Audretsch, Pontus Braunerhjelm, and Bo Carlsson, 2005, "Growth and Entrepreneurship: An Empirical Assessment;" Discussion Paper 3205, Max Planck Institute of Economics, Jena, Germany.

Appalachian Regional Commission, 2008, Accesses at www.arc.gov, November 21, 2008.

Aquilina, Matteo, Rainer Klump, and Carlo Pietrobelli, 2006, "Factor Substitution, Average Firm Size and Economic Growth, Small Business Economics, 26(3), 203-214.

Arrow, Kenneth J., 1962, "Economic Welfare and the Allocation of Resources for Invention", The Rate and Direction of Inventive Activity, Princeton, Princeton University Press, 609-626.

Audretsch, David B., 1995, Innovation and Industry Evolution, Cambridge, MA: MIT Press.

Audretsch David B. and A. Roy Thurik, 1997, Sources of Growth: The Entrepreneurial versus the Managed Economy, Discussion Paper TI97-109/3, Tinbergen Institute, Erasmus University Rotterdam.

Audretsch David B. and Max C. Keilbach, 2005, Entrepreneurship Capital and Regional Growth," The Annals of Regional Science 39, 457-469. 
Audretsch David B., Max C. Keilbach, and Eril E. Lehmann, 2006, Entrepreneurship and Economic Growth, Oxford University Press, Oxfrod, New York.

Baptista, Rui, Vitor Escaria, and Paulo Madruga, 2005, "Entrepreneurship, Regional Development and Job Creation : the Case of Portugal," Discussion Paper 605, Max Planck Institute into Economic Systems, Jena, Germany.

Baumol, William J., 1993, Entrepreneurship, Management, and the Structure of Payoffs, Cambridge, Massachusetts: MIT Press

Baumol, William J., Robert E. Litan, and Carl J. Schramm, 2007, Good Capitalism, Bad Capitalism, and the Economics of Growth and Prosperity, New Haven, Yale University Press.

Beck, Thorsten, Asli Demirguc-Kunt, and Ross Levine, 2005, "SMEs, Growth, and Poverty," NBER Working Paper No. W11224 (http://www.nber.org/papers/w11224.pdf).

Beugelsdijk, Sjoerd and Niels Noorderhaven, 2004, "Entrepreneurial Attitude and Economic Growth: a Cross-Section of 54 Regions,” The Annals of Regional Science 38, 199-218.

Black, Dan A. and Seth G. Sanders, 2004, "Labor Market Performance, Poverty, and Income Inequality in Appalachia," Demographic and Socio-Economic Change in Appalachia Report Series, Appalachian Regional Commission.

Camp, Michael, 2005, “The Innovation-Entrepreneurship NEXUS: A National Assessment of Entrepreneurship and Regional Economic Growth and Development," Small Business Research Summary No. 256, Advanced Research Technologies, Powell, OH.

Carland, James W. Jo Ann C. Carland, and James Carland III, 1995, "A Model of Entrepreneurship: The Process of Venture Creation," Accessed on January 23, 2009 from http://www.sbaer.uca.edu/research/sbida/1995/pdf/02.pdf

Carlino, Gerald A. and Edwin S. Mills, 1987, "The Determinants of County Growth," Journal of Regional Science 27, 39-54.

Carree, Martin A. and A. Roy Thurik, 1998, "Small Firms and Economic Growth in Europe," Atlantic Economic Journal 26(2), 137-146.

Casson, Mark, 1995, Entrepreneurship and Business Culture, Aldershot, UK and Brookfield, VT: Edward Elgar.

Ciccone, Antonio and Robert E. Hall, 1996, "Productivity and Density of Economic Activity," American Economic Review 86, 54-70.

Cole, Arthur H., 1946, "An Approach to the Study of Entrepreneurship: a Tribute to Edwin F. Gay," The Tasks of Economic History (Supplement VI of the Journal of Economic History), 1-15. 
Davis, Tim, 2006, "How many entrepreneurs does it take to change a nation?" Business Strategy Review 17(4), 68-73.

Deller, Steven C., Tsung-Hsui Tsai, David W. Marcouiller and Donald B.K. English, 2001, "The Role of Amenities and Quallity of Life in Rural Economic Growth," American Journal of Agricultural Economics, 83(2), 352-365.

Deller, Steven C.,2007, "The Role of Microenterprises in Economic Growth: A Panel Study of Wisconsin Counties 1977 to 1997," A paper presented at the $47^{\text {th }}$ Southern Regional Science Association Meeting, March 27-30, 2008, Arlington VA- Washington, DC.

Drabenstott, Mark, 2004, “A New Map for Rural America's New Economic Frontier," Economic Development America, Summer issue, 5-7.

Easterly, William, 2001, “The lost decade: Developing countries' stagnation in spite of policy reform 1980-1998," Journal of Economic Growth 6, 135.

Evans, David S. and Linda S. Leighton, 1989, "Some Empirical Aspects of Entrepreneurship," The American Economic Review 79(3), 519-535.

Folster, Stefan, 2000, "Do Entrepreneurs Create Jobs?” Small Business Economics 14(2), 137 148.

Fritsch, Michael and Pamela Mueller, 2004, "The Effects of New Business Transformation on Regional Development over Time," Regional Studies 38, 961-975.

Garrett, Thomas A. and Howard J. Wall, 2006, "Creating a Policy Environment for Entrepreneurs," Federal Reserve Bank of St. Louis Working Paper 2005-064B.

Gartner, William B., 1988, "Who is an 'Entrepreneur?' Is the Wrong Question," American Journal of Small Business 12(4), 11-32.

Goetz, Stephan J. and David Freshwater, 2001, "State-level Determinants of Entrepreneurship and a Preliminary Measure of Entrepreneurial Climate", Economic Development Quarterly 15, 58-70.

Greene, William H., 1997, Econometric Analysis, Saddle River, New Jersey, Prentice Hall.

Hagen, Everett E., 1962, On the Theory of Social Change: How Economic Growth Begins, Homewood, I11: Dorsey Press.

Hebert, Robert F. and Albert N. Link, 1989, "In Search of the Meaning of Entrepreneurship," Small Business Economics, 1(1), 39-49.

Henderson, Jason, 2006, "Understanding Rural Entrepreneurship at the County Level: Data Challenges," Federal Reserve Bank of Kansas City, Omaha. 
Isserman, Andrew M., 1996, "Socioeconomic Review of Appalachia - Appalachia Then and Now: An Update of 'The Realities of Deprivation' Reported to the President in 1964, Appalachian Regional Commission. Regional Research Report.

Jorgenson, Dale W., 2001, "Information Technology and the U.S. Economy," American Economic Review, 91(1), 1-32.

Kihlstrom Richard E. and Jean-Jacques Laffont, 1979, “A General Equilibrium Entrepreneurial Theory of Firm Formation Based on Risk Aversion," Journal of Political Economy, 87(4), 719748.

Kirzner, Israel M., 1979, Perception, Opportunity, and Profit: Studies in the Theory of Entrepreneurship, Chicago: The University of Chicago Press.

Knight, Frank H., 1921, Risk, Uncertainty, and Profit, Boston and New York: Houghton Mifflin Company.

Kreft, Steven F. and Russell S. Sobel, 2005, "Public Policy, Entrepreneurship, and Economic Freedom," Cato Journal, 25 (Fall), 595-616.

Kuzents, Simon, 1966, “Modern economic growth, New Haven: Yale University Press.

Lichtenstein, Gregg A. and Thomas A. Lyons, 2001, “The Entrepreneurial Development System: Transforming Business Talent and Community Economies," Economic Development Quarterly 15(1), 3-20.

Low, Sarah, Jason Henderson, and Stephan Weiler, 2005, “Gauging a Region's Entrepreneurial Potential," Economic Review, Federal Reserve Bank of Kansas City 90(3), 61-89.

Lucas, Robert Jr., 1988, "On the Mechanics of Economic Development," Journal of Monetary Economics, 22, 3-42.

McClelland, David C., 1961, The Achieving Society, Princeton, NJ: van Nostrand.

Mills, Edwin and Richard Price, 1984, "Metropolitan Suburbanization and Central City Problems," Journal of Urban Economics 15, 1-17.

Minniti, Maria, 1999, "Entrepreneurial Activity and Economic Growth," Global Business and Economic Review, 1(1), 31-42.

Montanye, James A., 2006, “Entrepreneurship,” Independent Review 10(4), 547-569.

Nzaku, Kilungu and James O. Bukenya, 2005, "Examining the Relationship between Quality of Life Amenities and Economic Development in the Southeast USA," Review of Urban and Regional Development Studies, 17(2), 89-105. 
Pollard, Kelvin M., 2003, "Appalachia at the Millennium: An Overview of the Results from Census 2000," Population Reference Bureau, Washington, DC.

Porter, Michael E., 1990, The Competitive Advantage of Nations, New York: The Free Press. Robinson, Kenneth L., Wylin Dassie, and Ralph D. Christy, 2004, "Entrepreneurship and Small Business Development as a Rural Development Strategy," Southern Rural Sociology 20(2),1-23.

Romer, Paul M., 1986, "Increasing Returns and Long-Run Growth," Journal of political Economy, 94, 1002-1037.

Sadeghi, Akbar, 2008, "The births and deaths of business establishments in the United States," Monthly Labor Review, December 2008.

Schmookler, Jacob, 1966, Invention and Economic Growth, Cambridge, MA: Harvard University Press.

Schultz, Theodore W., 1980, Investment in Entrepreneurial Ability," Scandinavian Journal of Economics 82, 437-448.

Schultz, Theodore W., 1988, "Education Investments and Returns. H. Chenery \& T.N. Srinivasan (Eds.), Handbook of development economics, Amsterdam/New York: North-Holland.

Schumpeter, Joseph A., 1934, The Theory of Economic Development, Cambridge, MA: Harvard University Press.

Shane, Scott and Sankaran Venkataraman, 2000, "The Promise of Entrepreneurship as a Filed of Research," Academy of Management Review, 25, 217-221.

Smilor Raymond W.,1997, "Entrepreneurship and Community Development," a paper presented at the Kaufmann Center for Entrepreneurship, Leadership Conference on Entrepreneurship as a Community Development Strategy.

Solow, Robert M., 1956, “A Contribution to Theory of Economic Growth,” Quarterly Journal of Economics, 70, 65-94.

Storey, David J., 2003, "Entrepreneurship, Small and Medium Sized Enterprises and Public Policies," in Z.J. Acs and D. Audretsch, Handbook of Entrepreneurship Research, Boston, Kluwer, 473-514.

van Stel, Andre, 2006, Empirical Analysis of Entrepreneurship and Economic Growth, New York, NY: Springer Science+Business Media, Inc.

van Stel Andre And Kashifa Suddle, 2005, "The Impact of New Firm Formation on Regional Development in the Netherlands," ERIM Report Series in Management. 
Wennekers Sander and A. Roy Thurik, 1999, Linking Entrepreneurship and Economic Growth," Small Business Economics 13, 27-55.

Wooldridge, Jeffrey, 2002, Econometric Analysis of Cross Section and Panel Data, MIT Press, London.

Xue, Jianhong, 2007, “Three Essays on Entrepreneurship: Theory, Measurement, and Environment," Unpublished PhD Dissertation, University of Missouri-Columbia. 
APPENDIX

Key Measures and Ranking of Entrepreneurial Activity in Appalachian Counties

\begin{tabular}{|c|c|c|c|c|c|c|c|c|c|c|c|}
\hline State & County & $\begin{array}{c}\text { Proprietors } \\
\text { per 1000 } \\
\text { Labor } \\
\text { Force } \\
\text { (1995) }\end{array}$ & Rank & $\begin{array}{l}\text { Growth in } \\
\text { Proprietors } \\
\text { per } 1000 \\
\text { Labor } \\
\text { Force } \\
(1995-2005)\end{array}$ & Rank & $\begin{array}{c}\text { Firm } \\
\text { Births } \\
\text { per 1000 } \\
\text { Labor } \\
\text { Force } \\
(1998)\end{array}$ & Rank & $\begin{array}{l}\text { Growth in } \\
\text { Firm Births } \\
\text { per } 1000 \\
\text { Labor } \\
\text { Force } \\
(1998-2005)\end{array}$ & Rank & $\begin{array}{c}\text { Firm } \\
\text { Deaths } \\
\text { per 1000 } \\
\text { Labor } \\
\text { Force } \\
(1998)\end{array}$ & Rank \\
\hline $\mathrm{AL}$ & Bibb & 168.574 & 201 & 85.322 & 70 & 6.213 & 55 & -1.070 & 300 & 4.364 & 305 \\
\hline $\mathrm{AL}$ & Blount & 185.116 & 142 & 204.068 & 6 & 6.499 & 44 & -2.923 & 392 & 4.281 & 293 \\
\hline $\mathrm{AL}$ & Calhoun & 127.967 & 335 & 31.218 & 210 & 4.119 & 199 & -1.382 & 337 & 3.263 & 139 \\
\hline $\mathrm{AL}$ & Chambers & 115.469 & 371 & 80.320 & 75 & 4.196 & 188 & -0.966 & 284 & 3.488 & 184 \\
\hline $\mathrm{AL}$ & Cherokee & 201.340 & 96 & 60.424 & 111 & 4.921 & 121 & -0.124 & 148 & 5.368 & 362 \\
\hline $\mathrm{AL}$ & Chilton & 175.870 & 175 & 17.760 & 263 & 7.328 & 28 & -2.516 & 385 & 6.340 & 392 \\
\hline $\mathrm{AL}$ & Clay & 115.479 & 370 & 88.831 & 64 & 2.603 & 384 & 0.892 & 41 & 2.912 & 85 \\
\hline AL & Cleburne & 209.841 & 81 & 84.818 & 72 & 4.135 & 194 & 0.866 & 44 & 4.001 & 267 \\
\hline $\mathrm{AL}$ & Colbert & 115.792 & 368 & 53.091 & 128 & 3.682 & 264 & 0.112 & 119 & 4.204 & 286 \\
\hline $\mathrm{AL}$ & Coosa & 152.050 & 248 & 28.290 & 229 & 3.470 & 292 & 0.890 & 42 & 7.134 & 397 \\
\hline $\mathrm{AL}$ & Cullman & 149.078 & 259 & 89.806 & 61 & 5.092 & 109 & -1.377 & 335 & 4.051 & 272 \\
\hline $\mathrm{AL}$ & De Kalb & 162.090 & 219 & 66.764 & 99 & 3.690 & 262 & -0.485 & 213 & 3.040 & 99 \\
\hline $\mathrm{AL}$ & Elmore & 225.410 & 62 & 33.555 & 200 & 6.496 & 45 & -1.737 & 360 & 4.513 & 318 \\
\hline $\mathrm{AL}$ & Etowah & 141.917 & 278 & 45.114 & 159 & 4.167 & 190 & -0.206 & 163 & 3.588 & 198 \\
\hline $\mathrm{AL}$ & Fayette & 102.529 & 399 & 113.428 & 40 & 3.561 & 277 & 0.077 & 121 & 3.395 & 166 \\
\hline $\mathrm{AL}$ & Franklin & 183.821 & 145 & -25.173 & 379 & 4.278 & 180 & -1.062 & 298 & 4.398 & 308 \\
\hline $\mathrm{AL}$ & Hale & 141.485 & 281 & 79.691 & 76 & 5.541 & 80 & -1.455 & 342 & 3.908 & 251 \\
\hline $\mathrm{AL}$ & Jackson & 170.704 & 192 & 32.670 & 204 & 3.887 & 226 & -0.827 & 265 & 3.727 & 224 \\
\hline $\mathrm{AL}$ & Jefferson & 103.854 & 396 & 44.441 & 160 & 3.655 & 269 & -0.340 & 186 & 3.400 & 168 \\
\hline $\mathrm{AL}$ & Lamar & 136.414 & 303 & 77.346 & 82 & 3.106 & 333 & 0.574 & 70 & 5.280 & 361 \\
\hline AL & Lauderdale & 138.620 & 295 & 61.362 & 109 & 4.578 & 148 & -0.182 & 158 & 4.808 & 340 \\
\hline $\mathrm{AL}$ & Lawrence & 186.091 & 139 & 99.070 & 51 & 3.260 & 317 & 0.129 & 117 & 2.582 & 50 \\
\hline $\mathrm{AL}$ & Limestone & 125.982 & 344 & 203.231 & 7 & 3.516 & 286 & 0.275 & 98 & 2.670 & 56 \\
\hline
\end{tabular}




\begin{tabular}{|c|c|c|c|c|c|c|c|c|c|c|c|}
\hline $\mathrm{AL}$ & Macon & 76.505 & 409 & 79.610 & 77 & 2.107 & 396 & -0.234 & 169 & 4.213 & 287 \\
\hline $\mathrm{AL}$ & Madison & 122.233 & 355 & -5.856 & 351 & 4.210 & 186 & -0.688 & 244 & 3.298 & 150 \\
\hline $\mathrm{AL}$ & Marion & 101.546 & 400 & 85.624 & 69 & 4.800 & 132 & -1.533 & 347 & 3.623 & 207 \\
\hline $\mathrm{AL}$ & Marshall & 159.219 & 228 & -47.281 & 397 & 4.520 & 156 & -1.127 & 309 & 4.135 & 283 \\
\hline $\mathrm{AL}$ & Morgan & 143.784 & 275 & 14.899 & 280 & 4.851 & 127 & -1.399 & 340 & 4.099 & 276 \\
\hline $\mathrm{AL}$ & Pickens & 152.132 & 247 & 68.269 & 97 & 4.690 & 138 & -0.555 & 226 & 4.748 & 334 \\
\hline $\mathrm{AL}$ & Randolph & 149.712 & 257 & 39.748 & 175 & 4.079 & 204 & 0.468 & 79 & 4.430 & 310 \\
\hline $\mathrm{AL}$ & Shelby & 233.875 & 50 & 11.173 & 297 & 6.739 & 34 & 17.022 & 2 & 15.260 & 404 \\
\hline $\mathrm{AL}$ & St. Clair & 168.338 & 202 & -22.239 & 377 & 9.649 & 10 & -8.093 & 407 & 1.556 & 8 \\
\hline $\mathrm{AL}$ & Talladega & 125.479 & 345 & 6.649 & 311 & 4.086 & 203 & -1.333 & 329 & 2.984 & 92 \\
\hline $\mathrm{AL}$ & Tallapoosa & 123.430 & 352 & 30.520 & 214 & 2.884 & 359 & 0.639 & 66 & 4.227 & 288 \\
\hline $\mathrm{AL}$ & Tuscaloosa & 111.082 & 383 & 19.338 & 255 & 4.584 & 147 & -1.179 & 316 & 3.761 & 232 \\
\hline $\mathrm{AL}$ & Walker & 178.408 & 170 & 167.332 & 15 & 5.887 & 69 & -1.508 & 345 & 4.687 & 328 \\
\hline $\mathrm{AL}$ & Winston & 139.961 & 290 & 0.805 & 332 & 2.791 & 371 & 1.117 & 37 & 4.656 & 327 \\
\hline GA & Banks & 173.785 & 182 & 266.810 & 1 & 5.400 & 90 & -2.685 & 388 & 2.456 & 42 \\
\hline GA & Barrow & 234.100 & 49 & 78.521 & 79 & 6.375 & 48 & -0.534 & 224 & 3.435 & 176 \\
\hline GA & Bartow & 146.635 & 268 & 128.856 & 31 & 6.644 & 36 & -2.229 & 378 & 3.296 & 149 \\
\hline GA & Carroll & 131.037 & 325 & 59.745 & 114 & 4.879 & 125 & 0.320 & 94 & 3.899 & 249 \\
\hline GA & Catoosa & 170.761 & 191 & 176.138 & 12 & 3.775 & 244 & -0.721 & 252 & 3.054 & 104 \\
\hline GA & Chattooga & 124.762 & 348 & 85.858 & 67 & 3.333 & 312 & -0.378 & 195 & 2.660 & 55 \\
\hline GA & Cherokee & 271.438 & 21 & 11.706 & 294 & 12.851 & 5 & -3.542 & 397 & 4.318 & 296 \\
\hline GA & Dade & 266.823 & 26 & 27.970 & 230 & 6.331 & 50 & -2.671 & 387 & 2.828 & 76 \\
\hline GA & Dawson & 377.119 & 3 & -65.177 & 404 & 19.068 & 4 & -10.531 & 408 & 3.616 & 206 \\
\hline GA & Douglas & 197.426 & 107 & 40.911 & 172 & 8.779 & 14 & -3.513 & 396 & 3.876 & 248 \\
\hline GA & Elbert & 170.067 & 196 & 34.585 & 194 & 5.100 & 107 & -1.224 & 320 & 5.168 & 354 \\
\hline GA & Fannin & 270.316 & 23 & 139.520 & 28 & 7.513 & 24 & -0.856 & 272 & 3.279 & 143 \\
\hline GA & Floyd & 116.914 & 366 & 49.933 & 140 & 4.236 & 182 & -1.086 & 303 & 3.370 & 161 \\
\hline GA & Forsyth & 233.009 & 52 & -164.523 & 409 & 10.933 & 6 & -0.465 & 211 & 4.932 & 346 \\
\hline GA & Franklin & 164.634 & 209 & 113.386 & 41 & 5.228 & 101 & -1.753 & 361 & 3.633 & 209 \\
\hline GA & Gilmer & 184.979 & 143 & 97.745 & 53 & 6.279 & 52 & 0.722 & 56 & 3.764 & 233 \\
\hline
\end{tabular}




\begin{tabular}{|c|c|c|c|c|c|c|c|c|c|c|c|}
\hline GA & Gordon & 103.771 & 397 & 45.486 & 158 & 4.121 & 198 & -0.179 & 157 & 2.393 & 36 \\
\hline GA & Gwinnett & 156.399 & 236 & -40.065 & 394 & 8.698 & 15 & -1.571 & 351 & 4.442 & 312 \\
\hline GA & Habersham & 154.179 & 242 & 62.583 & 106 & 4.624 & 142 & -0.045 & 136 & 3.496 & 185 \\
\hline GA & Hall & 129.606 & 329 & 50.384 & 136 & 5.594 & 78 & -0.389 & 197 & 3.451 & 178 \\
\hline GA & Haralson & 202.144 & 94 & 43.684 & 163 & 4.527 & 154 & -0.210 & 166 & 3.837 & 241 \\
\hline GA & Hart & 148.606 & 262 & 50.339 & 137 & 4.230 & 183 & -0.615 & 236 & 3.322 & 152 \\
\hline GA & Heard & 182.364 & 150 & 75.104 & 87 & 4.109 & 200 & 0.511 & 75 & 4.928 & 345 \\
\hline GA & Jackson & 158.862 & 231 & -28.729 & 385 & 6.984 & 32 & -0.215 & 167 & 3.261 & 138 \\
\hline GA & Lumpkin & 228.999 & 58 & 43.239 & 166 & 7.624 & 23 & -1.565 & 349 & 2.789 & 67 \\
\hline GA & Madison & 300.669 & 10 & 78.604 & 78 & 6.033 & 62 & -1.115 & 306 & 7.008 & 396 \\
\hline GA & Murray & 103.306 & 398 & 50.802 & 133 & 3.484 & 289 & -0.896 & 277 & 3.282 & 145 \\
\hline GA & Paulding & 275.335 & 18 & 167.032 & 16 & 10.323 & 9 & -4.609 & 402 & 2.771 & 65 \\
\hline GA & Pickens & 241.782 & 40 & 62.869 & 104 & 8.327 & 17 & 0.045 & 125 & 4.279 & 292 \\
\hline GA & Polk & 180.801 & 157 & 28.816 & 227 & 5.315 & 94 & -1.968 & 368 & 3.165 & 121 \\
\hline GA & Rabun & 173.694 & 183 & 60.200 & 113 & 7.504 & 25 & -0.828 & 267 & 4.117 & 281 \\
\hline GA & Stephens & 140.057 & 289 & 47.911 & 147 & 2.858 & 363 & 1.775 & 19 & 3.784 & 235 \\
\hline GA & Towns & 300.965 & 9 & 12.275 & 292 & 10.822 & 7 & -4.027 & 399 & 3.484 & 183 \\
\hline GA & Union & 287.637 & 14 & 36.108 & 190 & 10.798 & 8 & -3.782 & 398 & 4.611 & 323 \\
\hline GA & Walker & 181.941 & 152 & 24.066 & 245 & 5.000 & 116 & -1.393 & 339 & 3.952 & 258 \\
\hline GA & White & 232.890 & 53 & 117.803 & 37 & 9.638 & 11 & -2.888 & 390 & 5.199 & 357 \\
\hline GA & Whitfield & 82.161 & 408 & 10.179 & 302 & 3.486 & 287 & -0.210 & 165 & 3.289 & 147 \\
\hline KY & Adair & 145.258 & 270 & 36.838 & 185 & 3.819 & 240 & -0.155 & 153 & 2.809 & 71 \\
\hline KY & Bath & 164.911 & 207 & 31.835 & 207 & 4.624 & 143 & -0.368 & 193 & 4.255 & 289 \\
\hline KY & Bell & 127.433 & 340 & 11.562 & 295 & 4.207 & 187 & -1.046 & 296 & 5.573 & 374 \\
\hline KY & Boyd & 93.631 & 404 & 26.985 & 234 & 3.727 & 255 & -0.356 & 189 & 4.359 & 304 \\
\hline KY & Breathitt & 140.584 & 285 & 62.918 & 103 & 5.101 & 106 & 0.048 & 124 & 4.943 & 347 \\
\hline KY & Carter & 236.523 & 45 & -11.403 & 365 & 5.166 & 105 & -1.696 & 357 & 3.752 & 230 \\
\hline KY & Casey & 178.731 & 166 & 84.455 & 73 & 2.979 & 348 & -0.837 & 269 & 2.142 & 20 \\
\hline KY & Clark & 147.093 & 265 & 110.876 & 43 & 4.974 & 118 & -2.010 & 371 & 2.782 & 66 \\
\hline KY & Clay & 133.139 & 317 & 19.979 & 253 & 4.535 & 153 & -0.431 & 203 & 3.157 & 119 \\
\hline
\end{tabular}




\begin{tabular}{|c|c|c|c|c|c|c|c|c|c|c|c|}
\hline KY & Clinton & 172.998 & 184 & -67.230 & 406 & 4.355 & 168 & -1.289 & 325 & 3.066 & 107 \\
\hline KY & Cumberland & 172.021 & 185 & 54.339 & 124 & 3.012 & 346 & 1.522 & 26 & 3.238 & 133 \\
\hline KY & Edmonson & 155.238 & 240 & 59.567 & 115 & 3.133 & 330 & 2.025 & 16 & 2.427 & 39 \\
\hline KY & Elliott & 194.316 & 115 & 13.854 & 286 & 2.644 & 383 & 0.714 & 58 & 2.798 & 70 \\
\hline KY & Estill & 191.590 & 123 & 37.381 & 183 & 5.433 & 85 & -2.059 & 374 & 5.544 & 370 \\
\hline KY & Fleming & 187.973 & 131 & 39.565 & 176 & 2.783 & 373 & 1.607 & 22 & 4.097 & 275 \\
\hline KY & Floyd & 127.740 & 337 & 31.418 & 208 & 5.277 & 97 & 0.354 & 91 & 5.569 & 372 \\
\hline KY & Garrard & 221.027 & 68 & 147.366 & 23 & 5.177 & 102 & -0.483 & 212 & 3.999 & 266 \\
\hline KY & Green & 170.701 & 193 & 101.665 & 50 & 5.945 & 67 & -1.126 & 308 & 1.886 & 15 \\
\hline KY & Greenup & 153.276 & 244 & 61.923 & 107 & 2.740 & 377 & 0.571 & 71 & 3.850 & 246 \\
\hline KY & Harlan & 99.070 & 402 & -1.337 & 336 & 3.850 & 234 & 0.027 & 127 & 6.065 & 383 \\
\hline KY & Hart & 156.641 & 235 & 38.108 & 180 & 3.992 & 216 & -1.379 & 336 & 3.396 & 167 \\
\hline KY & Jackson & 194.258 & 116 & 42.454 & 167 & 3.140 & 327 & -1.349 & 333 & 3.185 & 124 \\
\hline KY & Johnson & 141.120 & 282 & 19.719 & 254 & 4.821 & 130 & -0.159 & 155 & 5.245 & 359 \\
\hline KY & Knott & 163.353 & 215 & 1.574 & 331 & 6.100 & 59 & -2.115 & 375 & 4.745 & 333 \\
\hline KY & Knox & 158.507 & 232 & 155.552 & 20 & 4.013 & 213 & -1.069 & 299 & 2.383 & 35 \\
\hline KY & Laurel & 144.758 & 272 & 3.214 & 323 & 4.487 & 160 & -1.358 & 334 & 2.865 & 79 \\
\hline KY & Lawrence & 234.199 & 48 & -30.945 & 387 & 5.286 & 96 & -0.849 & 271 & 4.859 & 343 \\
\hline KY & Lee & 194.708 & 114 & 18.707 & 257 & 2.765 & 375 & 2.974 & 9 & 2.869 & 80 \\
\hline KY & Leslie & 134.983 & 312 & 56.154 & 120 & 2.940 & 356 & 0.443 & 82 & 8.457 & 401 \\
\hline KY & Letcher & 130.707 & 326 & -9.634 & 361 & 6.131 & 58 & -1.785 & 363 & 5.588 & 375 \\
\hline KY & Lewis & 207.713 & 86 & 40.926 & 171 & 2.515 & 391 & 1.622 & 21 & 3.701 & 221 \\
\hline $\mathrm{KY}$ & Lincoln & 192.353 & 119 & 36.796 & 187 & 4.559 & 151 & -0.569 & 228 & 3.616 & 205 \\
\hline KY & Madison & 187.240 & 137 & 70.059 & 95 & 3.236 & 320 & 27.010 & 1 & 26.045 & 408 \\
\hline KY & Magoffin & 141.896 & 279 & 17.885 & 260 & 5.317 & 93 & -4.808 & 403 & 0.702 & 4 \\
\hline KY & Martin & 200.856 & 98 & 12.852 & 289 & 7.489 & 26 & -4.251 & 401 & 5.397 & 363 \\
\hline KY & McCreary & 148.794 & 260 & 2.481 & 326 & 4.361 & 167 & -0.024 & 133 & 2.296 & 27 \\
\hline KY & Menifee & 260.087 & 28 & 32.946 & 202 & 4.907 & 122 & -1.321 & 328 & 4.611 & 324 \\
\hline KY & $\begin{array}{l}\text { Monroe } \\
\text { Montgomer }\end{array}$ & 145.154 & 271 & 44.044 & 161 & 2.829 & 368 & 1.273 & 33 & 4.444 & 313 \\
\hline $\mathrm{KY}$ & $\mathrm{y}$ & 155.445 & 239 & 2.003 & 328 & 4.310 & 177 & -1.175 & 315 & 2.508 & 47 \\
\hline
\end{tabular}




\begin{tabular}{|c|c|c|c|c|c|c|c|c|c|c|c|}
\hline $\mathrm{KY}$ & Morgan & 164.381 & 210 & 37.176 & 184 & 4.072 & 205 & -1.348 & 332 & 2.335 & 32 \\
\hline KY & Owsley & 203.101 & 92 & 106.713 & 44 & 3.101 & 334 & 2.031 & 15 & 3.207 & 128 \\
\hline KY & Perry & 140.797 & 284 & -37.473 & 393 & 5.507 & 81 & -2.031 & 372 & 4.453 & 315 \\
\hline KY & Pike & 133.676 & 315 & 14.529 & 283 & 5.175 & 103 & -0.662 & 242 & 5.011 & 350 \\
\hline KY & Powell & 200.926 & 97 & 85.692 & 68 & 2.735 & 378 & 1.188 & 35 & 3.923 & 253 \\
\hline KY & Pulaski & 143.779 & 276 & -2.084 & 338 & 4.805 & 131 & -0.485 & 214 & 3.467 & 179 \\
\hline KY & Rockcastle & 151.608 & 249 & 30.162 & 216 & 3.795 & 242 & -1.336 & 330 & 1.932 & 17 \\
\hline KY & Rowan & 141.624 & 280 & -7.126 & 355 & 2.816 & 370 & 0.354 & 92 & 3.092 & 114 \\
\hline KY & Russell & 134.010 & 314 & 25.662 & 239 & 3.382 & 307 & 0.669 & 64 & 2.813 & 73 \\
\hline KY & Wayne & 121.542 & 357 & 4.097 & 319 & 3.074 & 339 & 0.373 & 89 & 2.891 & 82 \\
\hline KY & Whitley & 160.656 & 223 & -57.471 & 401 & 5.979 & 66 & -0.735 & 254 & 5.049 & 352 \\
\hline KY & Wolfe & 187.805 & 133 & 58.728 & 116 & 3.659 & 266 & 2.158 & 13 & 4.474 & 316 \\
\hline MD & Allegany & 131.850 & 321 & 17.796 & 262 & 3.730 & 252 & -1.004 & 289 & 3.600 & 201 \\
\hline MD & Garrett & 303.909 & 8 & 52.231 & 130 & 4.560 & 150 & -0.529 & 221 & 3.059 & 106 \\
\hline MD & Washington & 106.475 & 393 & -5.967 & 352 & 4.034 & 210 & -0.261 & 172 & 3.140 & 117 \\
\hline MS & Alcorn & 132.613 & 320 & 2.889 & 324 & 5.611 & 77 & -0.828 & 266 & 4.502 & 317 \\
\hline MS & Benton & 164.323 & 211 & 113.454 & 39 & 3.076 & 338 & 0.628 & 68 & 6.173 & 385 \\
\hline MS & Calhoun & 160.757 & 222 & 73.538 & 88 & 5.810 & 70 & -1.194 & 318 & 6.265 & 390 \\
\hline MS & Chickasaw & 131.773 & 323 & 33.943 & 197 & 3.934 & 222 & -0.017 & 132 & 5.595 & 376 \\
\hline MS & Choctaw & 176.549 & 174 & 77.147 & 83 & 6.625 & 38 & -3.131 & 393 & 5.644 & 377 \\
\hline MS & Clay & 112.807 & 378 & 57.301 & 119 & 3.477 & 290 & 0.178 & 112 & 4.347 & 300 \\
\hline MS & Itawamba & 125.424 & 346 & 96.684 & 56 & 4.960 & 119 & -0.387 & 196 & 4.115 & 279 \\
\hline MS & Kemper & 114.661 & 373 & 97.160 & 54 & 2.090 & 397 & 1.510 & 27 & 4.800 & 339 \\
\hline MS & Lee & 92.765 & 405 & 30.002 & 217 & 3.464 & 293 & -0.078 & 142 & 3.528 & 192 \\
\hline MS & Lowndes & 104.129 & 395 & 33.622 & 199 & 4.288 & 178 & -0.714 & 249 & 4.974 & 349 \\
\hline MS & Marshall & 195.805 & 110 & 11.302 & 296 & 4.353 & 169 & -0.318 & 182 & 4.331 & 298 \\
\hline MS & $\begin{array}{l}\text { Monroe } \\
\text { Montgomer }\end{array}$ & 136.892 & 302 & 27.249 & 232 & 3.259 & 318 & -0.216 & 168 & 4.597 & 321 \\
\hline MS & $\mathrm{y}$ & 187.752 & 134 & -4.220 & 347 & 4.991 & 117 & -1.402 & 341 & 6.507 & 394 \\
\hline MS & Noxubee & 114.351 & 376 & 48.449 & 145 & 3.929 & 224 & 0.955 & 39 & 4.070 & 274 \\
\hline MS & Oktibbeha & 112.302 & 380 & 28.845 & 226 & 3.423 & 296 & -0.449 & 207 & 2.736 & 62 \\
\hline
\end{tabular}




\begin{tabular}{|c|c|c|c|c|c|c|c|c|c|c|c|}
\hline MS & Panola & 110.480 & 386 & 60.232 & 112 & 5.406 & 89 & -1.882 & 365 & 4.111 & 278 \\
\hline MS & Pontotoc & 140.224 & 286 & 29.290 & 224 & 3.573 & 274 & -0.829 & 268 & 2.930 & 87 \\
\hline MS & Prentiss & 108.954 & 388 & 0.231 & 333 & 6.588 & 40 & -1.718 & 358 & 6.039 & 382 \\
\hline MS & Tippah & 145.471 & 269 & 5.016 & 316 & 2.999 & 347 & -0.442 & 205 & 3.934 & 255 \\
\hline MS & Tishomingo & 150.831 & 251 & -15.836 & 371 & 6.189 & 57 & -1.525 & 346 & 6.263 & 389 \\
\hline MS & Union & 149.097 & 258 & 15.535 & 276 & 2.966 & 351 & 0.640 & 65 & 2.950 & 89 \\
\hline MS & Webster & 163.559 & 213 & 14.587 & 282 & 3.390 & 305 & 0.483 & 78 & 4.703 & 330 \\
\hline MS & Winston & 138.325 & 297 & 41.006 & 170 & 3.726 & 256 & 1.283 & 32 & 4.031 & 269 \\
\hline MS & Yalobusha & 182.749 & 147 & 50.599 & 135 & 6.635 & 37 & -1.783 & 362 & 4.632 & 326 \\
\hline $\mathrm{NC}$ & Alexander & 193.056 & 118 & 89.260 & 63 & 3.377 & 309 & -0.935 & 281 & 3.318 & 151 \\
\hline $\mathrm{NC}$ & Alleghany & 188.951 & 129 & 72.550 & 92 & 7.117 & 30 & -1.571 & 350 & 2.447 & 41 \\
\hline $\mathrm{NC}$ & Ashe & 202.809 & 93 & 96.379 & 57 & 4.409 & 166 & -1.188 & 317 & 3.361 & 159 \\
\hline $\mathrm{NC}$ & Avery & 216.237 & 72 & 135.248 & 30 & 6.022 & 63 & -0.847 & 270 & 4.379 & 306 \\
\hline $\mathrm{NC}$ & Buncombe & 155.222 & 241 & 57.849 & 117 & 5.436 & 84 & -0.285 & 176 & 3.996 & 265 \\
\hline $\mathrm{NC}$ & Burke & 119.296 & 362 & 175.562 & 13 & 2.855 & 364 & -0.360 & 191 & 2.169 & 22 \\
\hline $\mathrm{NC}$ & Caldwell & 124.525 & 349 & 73.501 & 89 & 2.924 & 357 & 0.560 & 72 & 3.156 & 118 \\
\hline $\mathrm{NC}$ & Cherokee & 169.667 & 197 & 111.793 & 42 & 5.637 & 74 & -0.528 & 220 & 4.599 & 322 \\
\hline $\mathrm{NC}$ & Clay & 357.979 & 4 & 15.557 & 275 & 7.360 & 27 & 3.802 & 6 & 4.356 & 303 \\
\hline $\mathrm{NC}$ & Davie & 200.548 & 99 & 76.029 & 85 & 5.276 & 98 & -0.904 & 278 & 4.013 & 268 \\
\hline $\mathrm{NC}$ & Forsyth & 127.402 & 341 & 13.840 & 287 & 4.166 & 191 & -0.287 & 177 & 3.388 & 164 \\
\hline $\mathrm{NC}$ & Graham & 208.922 & 84 & 93.039 & 59 & 6.598 & 39 & -0.141 & 150 & 5.215 & 358 \\
\hline $\mathrm{NC}$ & Haywood & 200.383 & 100 & 76.072 & 84 & 6.544 & 41 & -0.933 & 280 & 4.848 & 342 \\
\hline $\mathrm{NC}$ & Henderson & 181.051 & 155 & 10.336 & 301 & 6.000 & 65 & -0.283 & 175 & 3.660 & 215 \\
\hline $\mathrm{NC}$ & Jackson & 171.332 & 188 & 51.467 & 132 & 6.220 & 54 & -1.347 & 331 & 3.598 & 200 \\
\hline $\mathrm{NC}$ & Macon & 129.812 & 328 & 24.031 & 246 & 3.032 & 344 & 3.651 & 7 & 3.962 & 260 \\
\hline $\mathrm{NC}$ & Madison & 246.830 & 36 & 34.933 & 193 & 8.251 & 18 & -5.998 & 406 & 1.559 & 9 \\
\hline $\mathrm{NC}$ & McDowell & 251.180 & 35 & 68.800 & 96 & 5.293 & 95 & 3.205 & 8 & 8.497 & 402 \\
\hline $\mathrm{NC}$ & Mitchell & 170.462 & 194 & -29.065 & 386 & 4.684 & 139 & 0.178 & 111 & 3.367 & 160 \\
\hline $\mathrm{NC}$ & Polk & 271.055 & 22 & 37.896 & 181 & 7.772 & 21 & -0.689 & 245 & 6.182 & 386 \\
\hline $\mathrm{NC}$ & Rutherford & 123.909 & 351 & 73.293 & 90 & 3.704 & 260 & 0.736 & 55 & 3.806 & 238 \\
\hline
\end{tabular}




\begin{tabular}{|c|c|c|c|c|c|c|c|c|c|c|c|}
\hline $\mathrm{NC}$ & Stokes & 265.855 & 27 & 46.400 & 153 & 4.904 & 123 & 0.858 & 46 & 4.063 & 273 \\
\hline $\mathrm{NC}$ & Surry & 114.511 & 375 & 48.299 & 146 & 3.828 & 237 & -0.321 & 184 & 3.342 & 156 \\
\hline $\mathrm{NC}$ & $\begin{array}{l}\text { Swain } \\
\text { Transylvani }\end{array}$ & 144.586 & 273 & -31.467 & 389 & 7.108 & 31 & -2.120 & 376 & 4.719 & 331 \\
\hline $\mathrm{NC}$ & $\mathrm{a}$ & 207.843 & 85 & 122.578 & 34 & 5.657 & 73 & 0.634 & 67 & 5.173 & 355 \\
\hline $\mathrm{NC}$ & Watauga & 178.524 & 168 & 20.440 & 250 & 6.052 & 60 & -0.940 & 282 & 4.415 & 309 \\
\hline $\mathrm{NC}$ & Wilkes & 150.436 & 255 & 48.548 & 144 & 3.762 & 246 & -0.777 & 259 & 2.597 & 52 \\
\hline $\mathrm{NC}$ & Yadkin & 211.324 & 78 & 5.453 & 314 & 4.837 & 128 & -0.792 & 263 & 3.846 & 244 \\
\hline $\mathrm{NC}$ & Yancey & 229.155 & 57 & 77.468 & 81 & 4.648 & 141 & 0.859 & 45 & 2.203 & 23 \\
\hline NY & Allegany & 195.266 & 113 & 64.109 & 101 & 3.546 & 281 & -0.046 & 137 & 3.547 & 195 \\
\hline NY & Broome & 131.788 & 322 & 25.856 & 238 & 2.843 & 366 & -0.341 & 187 & 2.966 & 91 \\
\hline NY & Cattaraugus & 153.506 & $\begin{array}{c}243 \\
\text { no }\end{array}$ & 29.643 & 219 & 3.038 & $\begin{array}{c}343 \\
\text { no }\end{array}$ & 0.258 & 99 & 2.943 & 88 \\
\hline NY & Chautauqua & & data & & no data & & data & & no data & & no data \\
\hline NY & Chemung & 116.120 & 367 & 46.241 & 155 & 2.537 & 389 & -0.098 & 145 & 3.079 & 111 \\
\hline NY & Chenango & 203.575 & 91 & 49.013 & 142 & 3.761 & 247 & -0.863 & 274 & 3.560 & 197 \\
\hline NY & Cortland & 164.642 & 208 & 89.702 & 62 & 3.395 & 302 & -0.598 & 233 & 3.112 & 115 \\
\hline NY & Delaware & 223.788 & 65 & 97.039 & 55 & 3.416 & 297 & 0.354 & 90 & 3.276 & 141 \\
\hline NY & Otsego & 189.125 & 128 & -56.055 & 399 & 3.089 & 335 & 0.669 & 63 & 3.244 & 136 \\
\hline NY & Schoharie & 219.030 & 70 & -7.293 & 356 & 3.709 & 258 & -0.157 & 154 & 3.243 & 135 \\
\hline NY & Schuyler & 253.936 & 31 & 165.359 & 17 & 3.705 & 259 & -0.867 & 275 & 2.292 & 26 \\
\hline NY & Steuben & 146.972 & 266 & 16.889 & 268 & 2.671 & 381 & 0.774 & 50 & 2.719 & 60 \\
\hline NY & Tioga & 240.170 & 42 & -35.460 & 392 & 4.130 & 196 & -1.075 & 301 & 2.687 & 57 \\
\hline NY & Tompkins & 148.237 & 263 & -11.026 & 364 & 2.590 & 386 & -0.186 & 159 & 2.463 & 44 \\
\hline $\mathrm{OH}$ & Adams & 216.106 & 73 & 105.830 & 45 & 3.973 & 217 & -1.254 & 322 & 2.409 & 38 \\
\hline $\mathrm{OH}$ & Athens & 150.271 & 256 & 17.592 & 264 & 3.674 & 265 & -0.438 & 204 & 2.798 & 69 \\
\hline $\mathrm{OH}$ & Belmont & 158.937 & 229 & 24.308 & 244 & 5.011 & 115 & -1.605 & 353 & 4.348 & 302 \\
\hline $\mathrm{OH}$ & Brown & 246.061 & 38 & 150.607 & 22 & 6.303 & 51 & -2.856 & 389 & 2.700 & 59 \\
\hline $\mathrm{OH}$ & Carroll & 198.587 & 103 & 194.563 & 8 & 3.871 & 231 & -1.389 & 338 & 2.317 & 30 \\
\hline $\mathrm{OH}$ & Clermont & 222.720 & 67 & 77.905 & 80 & 5.078 & 110 & -1.077 & 302 & 3.158 & 120 \\
\hline $\mathrm{OH}$ & Columbiana & 180.120 & 161 & 51.716 & 131 & 3.882 & 229 & -0.768 & 258 & 3.964 & 261 \\
\hline
\end{tabular}




\begin{tabular}{|c|c|c|c|c|c|c|c|c|c|c|c|}
\hline $\mathrm{OH}$ & Coshocton & 162.045 & 220 & 141.907 & 26 & 2.709 & 379 & 0.239 & 102 & 2.898 & 83 \\
\hline $\mathrm{OH}$ & Gallia & 152.225 & 246 & 32.713 & 203 & 3.547 & 280 & -1.000 & 287 & 2.721 & 61 \\
\hline $\mathrm{OH}$ & Guernsey & 168.256 & 204 & 52.972 & 129 & 3.965 & 219 & -1.154 & 312 & 3.733 & 226 \\
\hline $\mathrm{OH}$ & Harrison & 211.505 & 77 & -65.980 & 405 & 4.134 & 195 & 0.489 & 77 & 6.472 & 393 \\
\hline $\mathrm{OH}$ & Highland & 192.205 & 120 & 4.124 & 318 & 3.821 & 239 & -0.447 & 206 & 2.917 & 86 \\
\hline $\mathrm{OH}$ & Hocking & 201.981 & 95 & 29.984 & 218 & 5.318 & 92 & -2.360 & 381 & 4.294 & 294 \\
\hline $\mathrm{OH}$ & Holmes & 195.464 & 112 & 55.908 & 121 & 3.877 & 230 & -0.555 & 227 & 1.717 & 10 \\
\hline $\mathrm{OH}$ & Jackson & 158.907 & 230 & 19.219 & 256 & 3.143 & 326 & 0.221 & 104 & 2.447 & 40 \\
\hline $\mathrm{OH}$ & Jefferson & 135.306 & 310 & -1.142 & 335 & 2.903 & 358 & 0.144 & 115 & 4.126 & 282 \\
\hline $\mathrm{OH}$ & Lawrence & 198.780 & 102 & 54.559 & 123 & 3.852 & 233 & -0.161 & 156 & 4.522 & 319 \\
\hline $\mathrm{OH}$ & Meigs & 230.157 & 56 & 36.797 & 186 & 4.569 & 149 & 0.537 & 73 & 4.947 & 348 \\
\hline $\mathrm{OH}$ & Monroe & 191.144 & 125 & 135.686 & 29 & 3.406 & 299 & 0.429 & 85 & 4.169 & 285 \\
\hline $\mathrm{OH}$ & Morgan & 180.915 & 156 & 180.451 & 11 & 2.056 & 399 & 2.330 & 11 & 1.907 & 16 \\
\hline $\mathrm{OH}$ & Muskingum & 128.035 & 334 & 17.875 & 261 & 3.551 & 279 & -0.703 & 247 & 2.995 & 96 \\
\hline $\mathrm{OH}$ & Noble & 204.704 & 90 & -26.795 & 382 & 1.863 & 401 & 1.687 & 20 & 4.339 & 299 \\
\hline $\mathrm{OH}$ & Perry & 236.860 & 44 & -59.993 & 402 & 3.883 & 228 & 0.218 & 105 & 4.101 & 277 \\
\hline $\mathrm{OH}$ & Pike & 128.447 & 332 & 72.310 & 93 & 3.398 & 300 & -0.652 & 241 & 2.152 & 21 \\
\hline $\mathrm{OH}$ & Ross & 136.409 & 304 & 17.027 & 267 & 3.528 & 283 & -0.610 & 235 & 3.513 & 188 \\
\hline $\mathrm{OH}$ & Scioto & 143.408 & 277 & 16.369 & 270 & 3.728 & 254 & -1.050 & 297 & 3.232 & 131 \\
\hline $\mathrm{OH}$ & Tuscarawas & 161.832 & 221 & -16.459 & 372 & 3.348 & 311 & -0.268 & 173 & 3.428 & 174 \\
\hline $\mathrm{OH}$ & Vinton & 182.159 & 151 & 8.865 & 303 & 4.330 & 173 & -1.968 & 369 & 3.838 & 243 \\
\hline $\mathrm{OH}$ & Washington & 186.111 & 138 & -14.569 & 369 & 3.730 & 253 & -0.413 & 202 & 3.739 & 228 \\
\hline PA & Allegheny & 117.348 & 365 & 31.160 & 212 & 3.567 & 275 & -0.093 & 143 & 0.161 & 1 \\
\hline PA & Armstrong & 209.241 & 83 & 118.057 & 36 & 3.932 & 223 & -0.629 & 238 & 3.780 & 234 \\
\hline PA & Beaver & 175.135 & 179 & 13.891 & 284 & 4.060 & 206 & -0.406 & 201 & 3.680 & 220 \\
\hline PA & Bedford & 207.499 & 87 & 63.823 & 102 & 4.779 & 134 & -0.860 & 273 & 2.655 & 54 \\
\hline PA & Blair & 132.829 & 319 & -4.070 & 346 & 3.428 & 295 & -0.405 & 200 & 2.758 & 64 \\
\hline PA & Bradford & 179.744 & 163 & 35.246 & 192 & 3.998 & 215 & -0.292 & 179 & 2.910 & 84 \\
\hline $\mathrm{PA}$ & Butler & 181.853 & 153 & -7.857 & 357 & 4.694 & 137 & -0.206 & 164 & 3.202 & 126 \\
\hline PA & Cambria & 139.327 & 292 & 34.108 & 196 & 3.410 & 298 & 0.040 & 126 & 3.134 & 116 \\
\hline
\end{tabular}




\begin{tabular}{|c|c|c|c|c|c|c|c|c|c|c|c|}
\hline $\mathrm{PA}$ & Cameron & 165.228 & 205 & -3.517 & 345 & 3.083 & 336 & 1.468 & 28 & 3.337 & 155 \\
\hline $\mathrm{PA}$ & Carbon & 195.662 & 111 & 65.750 & 100 & 3.591 & 272 & 0.417 & 86 & 2.986 & 93 \\
\hline PA & Centre & 140.076 & 288 & 7.846 & 305 & 2.972 & 350 & -0.299 & 180 & 2.459 & 43 \\
\hline $\mathrm{PA}$ & Clarion & 223.865 & 64 & -15.818 & 370 & 3.838 & 236 & -1.312 & 327 & 3.789 & 236 \\
\hline PA & Clearfield & 175.735 & 176 & -3.466 & 344 & 3.331 & 313 & 0.202 & 108 & 4.154 & 284 \\
\hline $\mathrm{PA}$ & Clinton & 156.799 & 234 & 45.952 & 157 & 2.844 & 365 & 0.449 & 81 & 3.346 & 157 \\
\hline $\mathrm{PA}$ & Columbia & 150.532 & 254 & 47.440 & 149 & 3.887 & 227 & -0.599 & 234 & 3.205 & 127 \\
\hline $\mathrm{PA}$ & Crawford & 193.874 & 117 & 43.422 & 165 & 1.932 & 400 & 1.292 & 31 & 3.290 & 148 \\
\hline PA & Elk & 127.456 & 339 & 32.484 & 205 & 8.546 & 16 & -4.932 & 404 & 3.514 & 189 \\
\hline PA & Erie & 135.195 & 311 & 10.902 & 298 & 3.138 & 328 & -0.149 & 152 & 3.191 & 125 \\
\hline PA & Fayette & 184.597 & 144 & 57.808 & 118 & 4.247 & 181 & -0.694 & 246 & 3.536 & 194 \\
\hline $\mathrm{PA}$ & Forest & 236.490 & 46 & -24.431 & 378 & 2.975 & 349 & -0.577 & 231 & 3.083 & 113 \\
\hline PA & Fulton & 180.453 & 159 & 7.635 & 306 & 3.523 & 285 & 0.315 & 95 & 2.848 & 78 \\
\hline PA & Greene & 176.952 & 173 & 12.586 & 290 & 3.586 & 273 & 0.090 & 120 & 2.313 & 29 \\
\hline PA & Huntingdon & 175.402 & 177 & 29.473 & 220 & 2.864 & 361 & 0.137 & 116 & 3.370 & 162 \\
\hline PA & Indiana & 179.938 & 162 & 15.781 & 273 & 3.656 & 268 & -1.011 & 291 & 2.990 & 95 \\
\hline PA & Jefferson & 223.343 & 66 & 1.917 & 330 & 5.042 & 112 & -1.546 & 348 & 4.347 & 301 \\
\hline PA & Juniata & 240.166 & 43 & 81.169 & 74 & 3.115 & 332 & 0.076 & 122 & 2.372 & 34 \\
\hline PA & Lackawanna & 126.986 & 342 & 28.699 & 228 & 3.545 & 282 & -0.121 & 147 & 3.416 & 173 \\
\hline PA & Lawrence & 181.620 & 154 & 5.079 & 315 & 4.754 & 135 & -1.102 & 305 & 3.604 & 202 \\
\hline PA & Luzerne & 131.337 & 324 & 3.564 & 320 & 3.390 & 303 & 0.253 & 101 & 3.332 & 154 \\
\hline PA & Lycoming & 136.391 & 305 & 18.343 & 258 & 2.876 & 360 & 0.116 & 118 & 3.637 & 211 \\
\hline PA & McKean & 177.695 & 172 & 10.348 & 300 & 3.390 & 304 & -0.061 & 138 & 3.242 & 134 \\
\hline PA & Mercer & 151.284 & 250 & 10.877 & 299 & 4.006 & 214 & -0.714 & 250 & 3.641 & 212 \\
\hline PA & Mifflin & 159.382 & 227 & 53.550 & 127 & 2.836 & 367 & 1.097 & 38 & 3.039 & 98 \\
\hline PA & Monroe & 198.419 & 104 & 15.604 & 274 & 5.385 & 91 & -0.367 & 192 & 3.904 & 250 \\
\hline PA & $\begin{array}{l}\text { Montour } \\
\text { Northumber }\end{array}$ & 86.302 & 406 & 157.383 & 19 & 1.770 & 402 & -0.275 & 174 & 2.327 & 31 \\
\hline PA & land & 160.251 & 225 & 5.556 & 313 & 3.154 & 324 & -0.190 & 160 & 3.612 & 204 \\
\hline PA & Perry & 279.249 & 17 & 1.936 & 329 & 5.038 & 113 & 0.692 & 61 & 3.349 & 158 \\
\hline PA & Pike & 287.731 & 13 & 38.290 & 179 & 6.361 & 49 & -0.455 & 208 & 2.644 & 53 \\
\hline
\end{tabular}




\begin{tabular}{|c|c|c|c|c|c|c|c|c|c|c|c|}
\hline $\mathrm{PA}$ & Potter & 244.615 & 39 & 27.379 & 231 & 4.497 & 157 & -0.715 & 251 & 4.777 & 336 \\
\hline $\mathrm{PA}$ & Schuylkill & 163.374 & 214 & 7.400 & 307 & 3.131 & 331 & 0.904 & 40 & 3.816 & 240 \\
\hline $\mathrm{PA}$ & Snyder & 170.427 & 195 & -7.988 & 358 & 3.314 & 316 & -0.743 & 256 & 3.051 & 101 \\
\hline PA & Somerset & 192.074 & 121 & 7.197 & 308 & 4.311 & 176 & -0.396 & 198 & 3.325 & 153 \\
\hline $\mathrm{PA}$ & $\begin{array}{l}\text { Sullivan } \\
\text { Susquehann }\end{array}$ & 274.029 & 19 & 31.310 & 209 & 3.749 & 249 & 2.031 & 14 & 5.440 & 367 \\
\hline $\mathrm{PA}$ & a & 300.615 & 11 & 55.428 & 122 & 4.053 & 208 & 0.757 & 53 & 4.627 & 325 \\
\hline PA & Tioga & 204.931 & 89 & -8.671 & 359 & 3.847 & 235 & -0.577 & 232 & 3.475 & 180 \\
\hline $\mathrm{PA}$ & Union & 137.809 & 299 & 26.834 & 235 & 3.363 & 310 & -0.007 & 131 & 2.826 & 75 \\
\hline PA & Venango & 178.941 & 165 & -26.312 & 380 & 3.688 & 263 & -0.464 & 210 & 3.076 & 110 \\
\hline PA & Warren & 171.798 & 187 & 20.457 & 249 & 2.521 & 390 & 0.416 & 87 & 3.280 & 144 \\
\hline $\mathrm{PA}$ & Washington & 171.839 & 186 & -5.084 & 349 & 4.327 & 174 & -0.096 & 144 & 3.521 & 190 \\
\hline $\mathrm{PA}$ & $\begin{array}{l}\text { Wayne } \\
\text { Westmorela }\end{array}$ & 252.413 & 33 & -60.910 & 403 & 7.720 & 22 & -0.456 & 209 & 5.878 & 380 \\
\hline $\mathrm{PA}$ & nd & 180.192 & 160 & -9.252 & 360 & 4.144 & 192 & -0.039 & 135 & 3.846 & 245 \\
\hline $\mathrm{PA}$ & Wyoming & 210.626 & 79 & -77.588 & 408 & 3.484 & 288 & 1.784 & 18 & 3.679 & 219 \\
\hline $\mathrm{SC}$ & Anderson & 128.274 & 333 & 70.977 & 94 & 4.784 & 133 & -0.507 & 216 & 3.940 & 256 \\
\hline $\mathrm{SC}$ & Cherokee & 85.171 & 407 & 31.120 & 213 & 5.046 & 111 & -1.946 & 367 & 3.957 & 259 \\
\hline $\mathrm{SC}$ & Greenville & 114.630 & 374 & 23.343 & 247 & 4.958 & 120 & -0.508 & 217 & 3.677 & 218 \\
\hline $\mathrm{SC}$ & Oconee & 127.457 & 338 & 33.925 & 198 & 5.626 & 76 & -0.353 & 188 & 3.987 & 263 \\
\hline $\mathrm{SC}$ & Pickens & 168.321 & 203 & 2.623 & 325 & 6.048 & 61 & -1.881 & 364 & 3.940 & 257 \\
\hline $\mathrm{SC}$ & Spartanburg & 106.921 & 392 & 25.494 & 240 & 4.430 & 163 & -0.077 & 141 & 3.651 & 214 \\
\hline $\mathrm{TN}$ & Anderson & 124.956 & 347 & 102.997 & 46 & 3.149 & 325 & -0.200 & 162 & 3.271 & 140 \\
\hline $\mathrm{TN}$ & Bledsoe & 189.830 & 127 & 143.171 & 25 & 3.703 & 261 & -1.208 & 319 & 3.742 & 229 \\
\hline $\mathrm{TN}$ & Blount & 168.757 & 200 & 49.693 & 141 & 6.380 & 47 & -2.031 & 373 & 3.500 & 187 \\
\hline $\mathrm{TN}$ & Bradley & 130.649 & 327 & 47.131 & 150 & 4.225 & 185 & -0.533 & 222 & 3.731 & 225 \\
\hline $\mathrm{TN}$ & Campbell & 188.569 & 130 & 50.714 & 134 & 4.603 & 145 & -1.251 & 321 & 3.288 & 146 \\
\hline $\mathrm{TN}$ & Cannon & 284.164 & 15 & 159.983 & 18 & 5.427 & 86 & -1.495 & 344 & 1.787 & 12 \\
\hline $\mathrm{TN}$ & Carter & 175.371 & 178 & 211.413 & 4 & 3.552 & 278 & -0.742 & 255 & 3.391 & 165 \\
\hline $\mathrm{TN}$ & Claiborne & 174.352 & 181 & 14.601 & 281 & 4.025 & 212 & -0.957 & 283 & 3.478 & 181 \\
\hline $\mathrm{TN}$ & Clay & 169.585 & 198 & 256.679 & 2 & 2.765 & 374 & -0.190 & 161 & 1.873 & 14 \\
\hline
\end{tabular}




\begin{tabular}{|c|c|c|c|c|c|c|c|c|c|c|c|}
\hline $\mathrm{TN}$ & Cocke & 165.061 & 206 & 73.128 & 91 & 3.135 & 329 & -0.253 & 171 & 3.412 & 172 \\
\hline $\mathrm{TN}$ & Coffee & 135.462 & 309 & 41.503 & 169 & 3.633 & 270 & -0.871 & 276 & 3.053 & 102 \\
\hline $\mathrm{TN}$ & Cumberland & 210.347 & 80 & 50.151 & 138 & 6.013 & 64 & -2.384 & 383 & 3.278 & 142 \\
\hline $\mathrm{TN}$ & De Kalb & 197.539 & 106 & 36.425 & 189 & 2.859 & 362 & 0.450 & 80 & 2.989 & 94 \\
\hline $\mathrm{TN}$ & Fentress & 266.912 & 25 & 93.088 & 58 & 3.809 & 241 & -0.337 & 185 & 4.116 & 280 \\
\hline $\mathrm{TN}$ & Franklin & 191.762 & 122 & 49.001 & 143 & 4.228 & 184 & 0.757 & 52 & 3.178 & 123 \\
\hline $\mathrm{TN}$ & Grainger & 228.161 & 59 & 85.048 & 71 & 3.657 & 267 & -0.318 & 183 & 3.072 & 109 \\
\hline $\mathrm{TN}$ & Greene & 95.580 & 403 & 36.437 & 188 & 3.325 & 315 & -0.809 & 264 & 2.567 & 49 \\
\hline $\mathrm{TN}$ & Grundy & 307.981 & 7 & 152.632 & 21 & 2.817 & 369 & 0.676 & 62 & 5.433 & 366 \\
\hline $\mathrm{TN}$ & Hamblen & 119.064 & 363 & 27.180 & 233 & 3.185 & 322 & -0.987 & 285 & 3.527 & 191 \\
\hline $\mathrm{TN}$ & Hamilton & 118.553 & 364 & 34.577 & 195 & 4.103 & 201 & -0.493 & 215 & 3.726 & 223 \\
\hline $\mathrm{TN}$ & Hancock & 121.073 & 358 & 38.613 & 177 & 3.448 & 294 & -2.139 & 377 & 3.054 & 103 \\
\hline $\mathrm{TN}$ & Hawkins & 150.796 & 252 & 46.311 & 154 & 3.748 & 250 & -1.304 & 326 & 2.743 & 63 \\
\hline $\mathrm{TN}$ & Jackson & 429.555 & 2 & 180.715 & 10 & 2.233 & 395 & -1.152 & 311 & 2.027 & 18 \\
\hline $\mathrm{TN}$ & Jefferson & 183.330 & 146 & 91.067 & 60 & 3.603 & 271 & -0.002 & 130 & 2.595 & 51 \\
\hline $\mathrm{TN}$ & Johnson & 216.032 & 74 & 17.957 & 259 & 4.858 & 126 & -1.160 & 314 & 3.254 & 137 \\
\hline $\mathrm{TN}$ & Knox & 148.785 & 261 & 35.854 & 191 & 4.429 & 165 & -0.759 & 257 & 3.724 & 222 \\
\hline $\mathrm{TN}$ & Loudon & 179.665 & 164 & 32.191 & 206 & 6.191 & 56 & -1.945 & 366 & 3.977 & 262 \\
\hline $\mathrm{TN}$ & Macon & 127.918 & 336 & 102.596 & 47 & 3.239 & 319 & -2.345 & 379 & 0.931 & 5 \\
\hline $\mathrm{TN}$ & Marion & 178.488 & 169 & 140.492 & 27 & 4.043 & 209 & -0.028 & 134 & 3.814 & 239 \\
\hline $\mathrm{TN}$ & McMinn & 190.860 & 126 & 61.484 & 108 & 4.526 & 155 & 2.935 & 10 & 6.122 & 384 \\
\hline $\mathrm{TN}$ & Meigs & 496.055 & 1 & 124.658 & 32 & 1.479 & 405 & 0.064 & 123 & 2.401 & 37 \\
\hline $\mathrm{TN}$ & Monroe & 147.681 & 264 & -3.019 & 342 & 4.593 & 146 & -1.020 & 293 & 2.951 & 90 \\
\hline $\mathrm{TN}$ & Morgan & 231.762 & 54 & 182.469 & 9 & 3.325 & 314 & 0.169 & 113 & 2.700 & 58 \\
\hline $\mathrm{TN}$ & Overton & 218.816 & 71 & 101.755 & 49 & 3.014 & 345 & 0.003 & 129 & 4.525 & 320 \\
\hline $\mathrm{TN}$ & Pickett & 185.634 & 141 & 53.722 & 126 & 2.596 & 385 & 1.557 & 24 & 3.634 & 210 \\
\hline $\mathrm{TN}$ & Polk & 231.086 & 55 & -14.011 & 368 & 5.772 & 71 & -1.004 & 288 & 5.450 & 368 \\
\hline $\mathrm{TN}$ & Putnam & 157.163 & 233 & -2.718 & 340 & 4.477 & 161 & -0.510 & 218 & 3.990 & 264 \\
\hline $\mathrm{TN}$ & Rhea & 162.507 & 217 & 13.147 & 288 & 3.726 & 257 & 0.197 & 109 & 3.923 & 252 \\
\hline $\mathrm{TN}$ & Roane & 123.997 & 350 & -45.936 & 396 & 2.947 & 354 & 0.511 & 74 & 3.228 & 130 \\
\hline
\end{tabular}




\begin{tabular}{|c|c|c|c|c|c|c|c|c|c|c|c|}
\hline $\mathrm{TN}$ & Scott & 182.410 & 149 & 29.366 & 223 & 4.430 & 164 & -0.709 & 248 & 3.174 & 122 \\
\hline $\mathrm{TN}$ & Sequatchie & 221.022 & 69 & 47.543 & 148 & 3.952 & 221 & 0.604 & 69 & 2.506 & 46 \\
\hline $\mathrm{TN}$ & Sevier & 185.964 & 140 & -4.531 & 348 & 6.745 & 33 & -0.289 & 178 & 4.812 & 341 \\
\hline $\mathrm{TN}$ & Smith & 187.690 & 135 & 26.312 & 236 & 3.042 & 342 & -0.359 & 190 & 3.384 & 163 \\
\hline $\mathrm{TN}$ & Sullivan & 136.257 & 306 & 45.981 & 156 & 3.853 & 232 & -1.026 & 294 & 3.556 & 196 \\
\hline $\mathrm{TN}$ & Unicoi & 191.404 & 124 & 16.580 & 269 & 3.526 & 284 & -1.005 & 290 & 3.081 & 112 \\
\hline $\mathrm{TN}$ & Union & 246.691 & 37 & 22.951 & 248 & 3.471 & 291 & 1.259 & 34 & 3.497 & 186 \\
\hline $\mathrm{TN}$ & Van Buren & 227.504 & 60 & 170.808 & 14 & 3.396 & 301 & -1.286 & 324 & 2.532 & 48 \\
\hline $\mathrm{TN}$ & Warren & 178.675 & 167 & 3.430 & 321 & 3.177 & 323 & -0.788 & 260 & 4.270 & 290 \\
\hline $\mathrm{TN}$ & Washington & 120.551 & 360 & 4.211 & 317 & 4.282 & 179 & -1.160 & 313 & 3.484 & 182 \\
\hline $\mathrm{TN}$ & White & 196.804 & 109 & 43.453 & 164 & 3.379 & 308 & -0.552 & 225 & 3.597 & 199 \\
\hline VA & Alleghany & 129.182 & 330 & -56.196 & 400 & 1.656 & 403 & 4.949 & 4 & 3.633 & 208 \\
\hline VA & Bath & 200.201 & 101 & 30.437 & 215 & 4.345 & 171 & 3.843 & 5 & 3.071 & 108 \\
\hline VA & Bland & 227.441 & 61 & 98.464 & 52 & 1.121 & 406 & -0.791 & 262 & 0.593 & 3 \\
\hline VA & Botetourt & 135.784 & 307 & 62.600 & 105 & 4.339 & 172 & 0.433 & 84 & 5.941 & 381 \\
\hline VA & Buchanan & 269.327 & 24 & 235.464 & 3 & 44.888 & 1 & -20.936 & 409 & 46.707 & 409 \\
\hline VA & Carroll & 180.728 & 158 & 40.852 & 173 & 9.592 & 12 & -1.133 & 310 & 7.840 & 399 \\
\hline VA & Craig & 252.103 & 34 & 102.513 & 48 & 1.078 & 407 & 0.238 & 103 & 1.152 & 6 \\
\hline VA & Dickenson & 144.477 & 274 & 20.252 & 251 & 2.401 & 393 & 0.718 & 57 & 3.402 & 169 \\
\hline VA & Floyd & 240.338 & 41 & -28.045 & 384 & 4.494 & 158 & 2.178 & 12 & 3.235 & 132 \\
\hline VA & Giles & 254.098 & 30 & 67.184 & 98 & 20.864 & 2 & -0.401 & 199 & 22.510 & 407 \\
\hline VA & Grayson & 133.404 & 316 & 114.680 & 38 & 1.646 & 404 & 0.697 & 59 & 2.236 & 24 \\
\hline VA & Highland & 100.930 & 401 & 24.709 & 243 & 0.376 & 409 & 0.209 & 107 & 0.372 & 2 \\
\hline VA & $\begin{array}{l}\text { Lee } \\
\text { Montgomer }\end{array}$ & 140.839 & 283 & 26.168 & 237 & 3.082 & 337 & -0.632 & 239 & 3.430 & 175 \\
\hline VA & $\mathrm{y}$ & 137.623 & 301 & 8.223 & 304 & 19.265 & 3 & 1.164 & 36 & 20.428 & 406 \\
\hline VA & Pulaski & 113.997 & 377 & 50.065 & 139 & 3.068 & 340 & 0.257 & 100 & 2.798 & 68 \\
\hline VA & Rockbridge & 139.832 & 291 & -20.092 & 374 & 0.739 & 408 & 0.844 & 47 & 1.350 & 7 \\
\hline VA & Russell & 138.530 & 296 & -13.098 & 366 & 4.103 & 202 & -1.692 & 356 & 4.040 & 271 \\
\hline VA & Scott & 108.513 & 390 & 61.199 & 110 & 2.746 & 376 & -1.041 & 295 & 2.355 & 33 \\
\hline VA & Smyth & 126.479 & 343 & 122.865 & 33 & 3.045 & 341 & -1.123 & 307 & 2.812 & 72 \\
\hline
\end{tabular}




\begin{tabular}{|c|c|c|c|c|c|c|c|c|c|c|c|}
\hline VA & Tazewell & 121.591 & 356 & 12.317 & 291 & 2.265 & 394 & -0.683 & 243 & 2.287 & 25 \\
\hline VA & Washington & 132.886 & 318 & 40.401 & 174 & 7.263 & 29 & -1.603 & 352 & 5.511 & 369 \\
\hline VA & Wise & 112.177 & 381 & 17.212 & 266 & 2.089 & 398 & -0.252 & 170 & 2.465 & 45 \\
\hline VA & Wythe & 112.712 & 379 & -26.358 & 381 & 2.947 & 353 & 0.438 & 83 & 3.611 & 203 \\
\hline WV & Barbour & 198.061 & 105 & 75.689 & 86 & 6.463 & 46 & -2.891 & 391 & 3.929 & 254 \\
\hline WV & Berkeley & 150.571 & 253 & 43.855 & 162 & 4.327 & 175 & 0.210 & 106 & 2.817 & 74 \\
\hline WV & Boone & 108.879 & 389 & 25.274 & 241 & 4.167 & 189 & -0.534 & 223 & 2.888 & 81 \\
\hline WV & Braxton & 163.792 & 212 & 15.942 & 272 & 5.936 & 68 & -3.407 & 395 & 5.564 & 371 \\
\hline WV & Brooke & 128.592 & 331 & 144.914 & 24 & 3.967 & 218 & -0.127 & 149 & 3.036 & 97 \\
\hline WV & Cabell & 105.552 & 394 & 28.979 & 225 & 2.944 & 355 & 0.763 & 51 & 3.646 & 213 \\
\hline WV & Calhoun & 338.241 & 5 & 31.212 & 211 & 5.424 & 87 & -2.466 & 384 & 4.438 & 311 \\
\hline WV & Clay & 233.060 & 51 & -27.066 & 383 & 8.200 & 19 & -4.067 & 400 & 6.200 & 388 \\
\hline WV & Doddridge & 279.777 & 16 & 120.741 & 35 & 4.055 & 207 & -1.096 & 304 & 1.849 & 13 \\
\hline WV & Fayette & 139.212 & 294 & 46.995 & 152 & 5.252 & 99 & -1.016 & 292 & 4.892 & 344 \\
\hline WV & Gilmer & 215.526 & 75 & -0.161 & 334 & 3.190 & 321 & 1.533 & 25 & 2.834 & 77 \\
\hline WV & Grant & 146.928 & 267 & 86.754 & 66 & 3.958 & 220 & -0.576 & 230 & 5.411 & 364 \\
\hline WV & Greenbrier & 171.220 & 189 & 15.081 & 277 & 5.557 & 79 & 0.415 & 88 & 5.021 & 351 \\
\hline WV & Hampshire & 234.208 & 47 & 87.421 & 65 & 4.137 & 193 & 0.186 & 110 & 3.799 & 237 \\
\hline WV & Hancock & 110.987 & 385 & -40.259 & 395 & 2.553 & 387 & 1.813 & 17 & 3.226 & 129 \\
\hline WV & Hardy & 119.605 & 361 & -5.992 & 353 & 2.646 & 382 & -0.118 & 146 & 3.676 & 217 \\
\hline WV & Harrison & 153.125 & 245 & 6.985 & 309 & 3.564 & 276 & -0.068 & 140 & 3.405 & 171 \\
\hline WV & Jackson & 155.626 & 238 & 33.043 & 201 & 4.546 & 152 & -0.791 & 261 & 3.837 & 242 \\
\hline WV & Jefferson & 212.716 & 76 & -10.127 & 363 & 5.249 & 100 & 1.323 & 30 & 4.315 & 295 \\
\hline WV & Kanawha & 111.023 & 384 & 20.009 & 252 & 3.791 & 243 & -0.527 & 219 & 3.733 & 227 \\
\hline WV & Lewis & 171.218 & 190 & -31.314 & 388 & 4.659 & 140 & 0.004 & 128 & 3.403 & 170 \\
\hline WV & Lincoln & 252.860 & 32 & -47.392 & 398 & 4.348 & 170 & 0.489 & 76 & 6.309 & 391 \\
\hline WV & Logan & 114.813 & 372 & -20.896 & 375 & 4.824 & 129 & -0.624 & 237 & 6.734 & 395 \\
\hline WV & Marion & 137.862 & 298 & -6.107 & 354 & 4.121 & 197 & 14.818 & 3 & 18.939 & 405 \\
\hline WV & Marshall & 159.652 & 226 & 17.274 & 265 & 3.757 & 248 & -2.352 & 380 & 2.089 & 19 \\
\hline WV & Mason & 111.794 & 382 & 207.270 & 5 & 3.745 & 251 & -2.616 & 386 & 1.775 & 11 \\
\hline
\end{tabular}




\begin{tabular}{|c|c|c|c|c|c|c|c|c|c|c|c|}
\hline WV & McDowell & 135.619 & 308 & 38.593 & 178 & 2.950 & 352 & -0.370 & 194 & 4.732 & 332 \\
\hline WV & Mercer & 134.145 & 313 & 29.382 & 222 & 4.026 & 211 & -0.308 & 181 & 4.033 & 270 \\
\hline WV & Mineral & 197.329 & 108 & -21.577 & 376 & 5.415 & 88 & -0.064 & 139 & 3.533 & 193 \\
\hline WV & Mingo & 109.837 & 387 & -9.763 & 362 & 5.446 & 83 & 0.323 & 93 & 9.651 & 403 \\
\hline WV & Monongalia & 115.490 & 369 & 6.856 & 310 & 3.913 & 225 & -0.573 & 229 & 3.048 & 100 \\
\hline WV & Monroe & 255.666 & 29 & 37.402 & 182 & 5.093 & 108 & 0.169 & 114 & 5.720 & 378 \\
\hline WV & Morgan & 271.540 & 20 & -5.199 & 350 & 5.729 & 72 & 0.787 & 49 & 3.054 & 105 \\
\hline WV & Nicholas & 140.211 & 287 & -1.574 & 337 & 6.700 & 35 & -3.141 & 394 & 7.297 & 398 \\
\hline WV & Ohio & 107.494 & 391 & -68.216 & 407 & 2.791 & 372 & -0.142 & 151 & 3.758 & 231 \\
\hline WV & Pendleton & 162.675 & 216 & 41.603 & 168 & 4.491 & 159 & -0.652 & 240 & 4.387 & 307 \\
\hline WV & Pleasants & 139.227 & 293 & 54.277 & 125 & 2.486 & 392 & 0.278 & 97 & 2.304 & 28 \\
\hline WV & Pocahontas & 175.042 & 180 & 29.431 & 221 & 3.769 & 245 & 0.742 & 54 & 4.698 & 329 \\
\hline WV & Preston & 209.548 & 82 & 24.816 & 242 & 6.524 & 43 & -1.254 & 323 & 4.319 & 297 \\
\hline WV & Putnam & 162.188 & 218 & 16.369 & 271 & 6.542 & 42 & -1.659 & 355 & 4.277 & 291 \\
\hline WV & Raleigh & 122.304 & 353 & 12.088 & 293 & 5.636 & 75 & -0.997 & 286 & 4.786 & 338 \\
\hline WV & Randolph & 160.526 & 224 & -3.392 & 343 & 5.502 & 82 & -0.731 & 253 & 3.670 & 216 \\
\hline WV & Ritchie & 224.276 & 63 & 14.970 & 279 & 5.019 & 114 & -2.001 & 370 & 5.094 & 353 \\
\hline WV & Roane & 315.482 & 6 & -13.447 & 367 & 2.686 & 380 & 1.590 & 23 & 4.447 & 314 \\
\hline WV & Summers & 187.907 & 132 & 3.229 & 322 & 3.388 & 306 & 1.397 & 29 & 4.785 & 337 \\
\hline WV & Taylor & 205.226 & 88 & -34.061 & 391 & 3.824 & 238 & 0.889 & 43 & 5.570 & 373 \\
\hline WV & Tucker & 120.927 & 359 & 47.032 & 151 & 2.546 & 388 & 0.813 & 48 & 5.426 & 365 \\
\hline WV & Tyler & 187.262 & 136 & 13.857 & 285 & 4.696 & 136 & -1.457 & 343 & 6.184 & 387 \\
\hline WV & Upshur & 178.247 & 171 & -2.235 & 339 & 4.441 & 162 & 0.695 & 60 & 3.852 & 247 \\
\hline WV & Wayne & 182.549 & 148 & -31.638 & 390 & 5.166 & 104 & -1.622 & 354 & 5.275 & 360 \\
\hline WV & Webster & 156.260 & 237 & 2.228 & 327 & 8.173 & 20 & -2.382 & 382 & 7.924 & 400 \\
\hline WV & Wetzel & 169.398 & 199 & -18.093 & 373 & 4.901 & 124 & 0.289 & 96 & 5.190 & 356 \\
\hline WV & Wirt & 294.312 & 12 & 6.231 & 312 & 9.259 & 13 & -5.867 & 405 & 4.749 & 335 \\
\hline WV & Wood & 122.246 & 354 & 15.013 & 278 & 4.615 & 144 & -0.918 & 279 & 3.446 & 177 \\
\hline WV & Wyoming & 137.685 & 300 & -2.956 & 341 & 6.252 & 53 & -1.723 & 359 & 5.802 & 379 \\
\hline
\end{tabular}

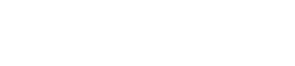

$\mathrm{H}$.

Hagen 